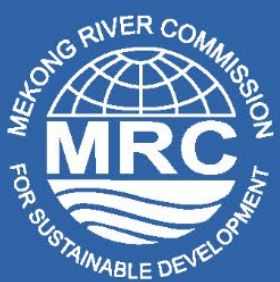

Mekong River Commission

For Sustainable Development

avor

$\triangle$ ANABLEDEVE
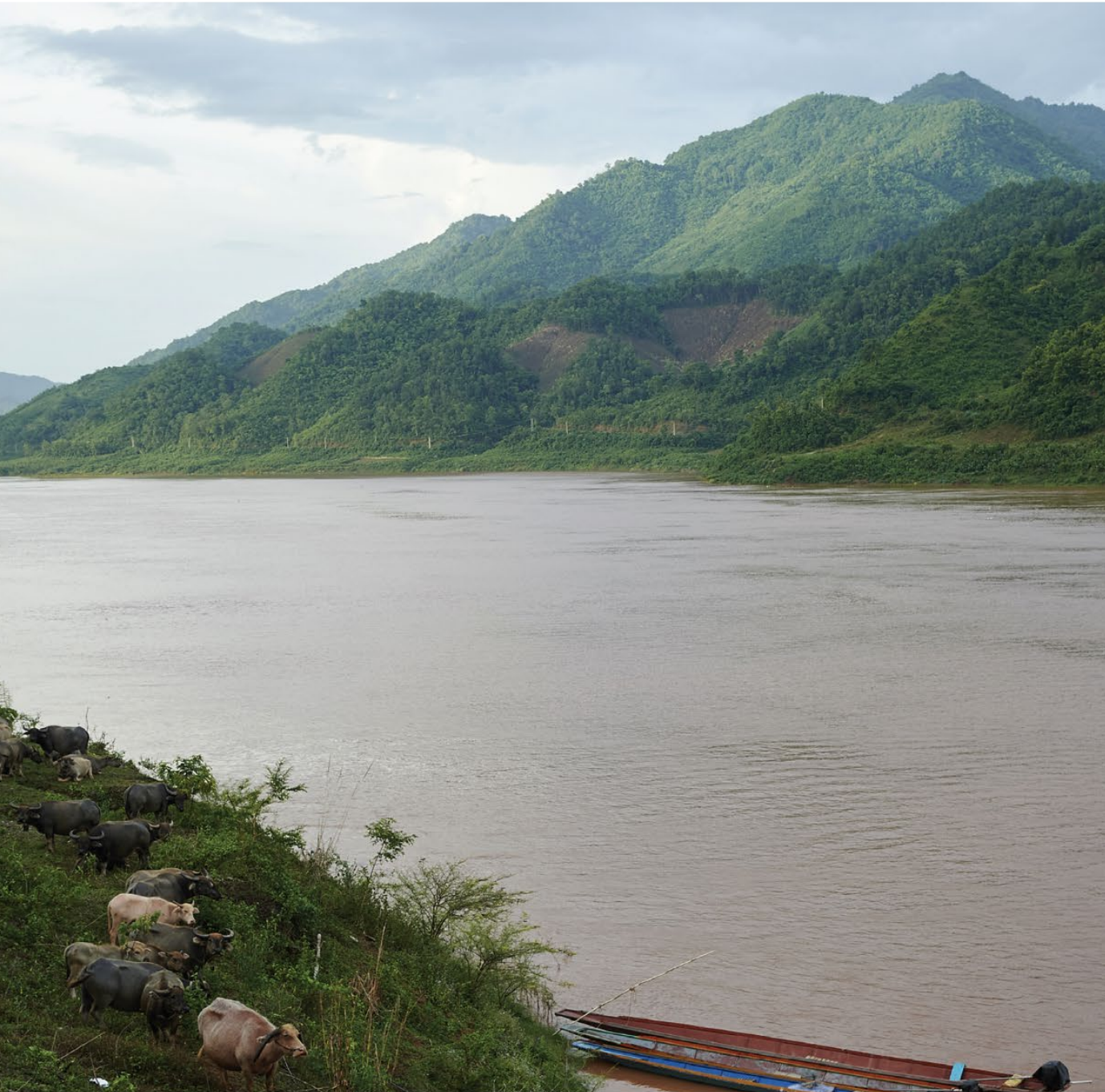

\title{
2018 LOWER MEKONG WATER QUALITY MONITORING REPORT
}




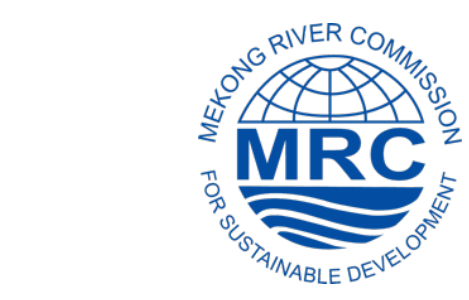

Mekong River Commission

\section{LOWER MEKONG WATER QUALITY MONITORING REPORT}

Mekong River Commission Secretariat October 2021 
The MRC is funded by contributions from its Member Countries and Development Partners, including Australia, the European Union, Finland, Flanders/Belgium, France, Germany, Japan, Luxembourg, the Netherlands, New Zealand, Sweden, Switzerland, United States of America and the World Bank. 


\section{Copyright @ Mekong River Commission, 2021}

First published (2010)

Some rights reserved.

This work is a product of the Mekong River Commission (MRC) Secretariat. While all efforts have been made to present accurate information, the MRC does not guarantee the accuracy of the data included in this work. The boundaries, colours, denomination and other information shown on any map in this work do not imply any judgement on the part of the MRC concerning the legal status of any territory or the endorsement or acceptance of such boundaries.

Nothing herein shall constitute or be considered to be a limitation upon or waiver of the privileges and immunities of the MRC, all of which are specifically reserved.

This publication may be reproduced, in whole or in part and in any form, for educational or non-profit purposes without special permission from the copyright holder provided that the MRC is acknowledged as the source and that notification is sent to the MRC. The MRC Secretariat would appreciate receiving a copy of any publication that uses this publication as a source. This publication cannot be used for sale or for any other commercial purpose whatsoever without permission in writing from the MRC Secretariat.

Title: 2018 Lower Mekong water quality report

DOI: $10.52107 / \mathrm{mrc} . q \times 5 y n z$

Keywords: water quality/human health/Procedures for Water Quality/Lower Mekong River Basin/Mekong River Commission/Transboundary River/Spatiotemporal trends

For bibliographic purposes, this volume may be cited as: Mekong River Commission. (2021). 2018 Lower Mekong water quality report. Vientiane: MRC Secretariat. https://doi.org/10.52107/mrc.qx5ynz

Information on MRC publications and digital products can be found at http://www.mrcmekong.org/publications

\section{All queries on rights and licenses should be addressed to:}

Mekong River Commission

Documentation and Learning Centre

184 Fa Ngoum Road, Unit 18, Ban Sithane Neua, Sikhottabong District, Vientiane 01000, Lao PDR Telephone: +856-21 263263 | E-mail: mrcs@mrcmekong.org | www.mrcmekong.org 


\section{Citation}

Mekong River Commission (2021). 2018 Lower Mekong water quality monitoring report. Vientiane: MRC Secretariat. https://doi.org/10.52107/mrc.qx5ynz

\section{Authors}

Technical expert and author

Dr Kongmeng Ly, Water Quality Programme Officer, MRC Secretariat

Technical experts and editors

Dr Prayooth Yaowakhan, Ecosystem and Wetland Specialist, MRC Secretariat

Dr So Nam, Chief Environment Management Officer, MRC Secretariat

\section{Management}

Mr Socheat Hak, Director of Environmental Management Division, MRC Secretariat

National contributors

Department of Hydrology and River Works, Ministry of Water Resources and Meteorology, Cambodia; Natural Resources and Environment Statistic Research Institute, Ministry of Natural Resources and Environment, Lao PDR; Research and Water Quality Analysis Division, Bureau of Research Development and Hydrology, Department of Water Resources, Ministry of Natural Resources and Environment, Thailand; Centre of Water Quality and Environment, Southern Institute for Water Resources Planning, Viet Nam; National Mekong Committee Secretariats of Cambodia, Lao PDR, Thailand and Viet Nam. 


\section{Contents}

$\begin{array}{llr}2.1 & \text { Background } & 1\end{array}$

2.2 Water quality monitoring network 1

$\begin{array}{llr}2.3 & \text { Objectives } & 3\end{array}$

$\begin{array}{lll}2.1 & \text { Monitoring location and frequency } & 4\end{array}$

$\begin{array}{lll}2.2 & \text { Sampling techniques } & 6\end{array}$

$\begin{array}{lll}2.3 & \text { Laboratory analytical methods } & 7\end{array}$

$\begin{array}{llr}2.4 & \text { Data analysis } & \mathbf{8}\end{array}$

$\begin{array}{lll}2.4 .1 & \text { Status and trends } & 8\end{array}$

$\begin{array}{ll}\text { 2.4.2 Transboundary water quality } & 9\end{array}$

$\begin{array}{ll}2.4 .3 & \text { Water quality indices }\end{array}$

$\begin{array}{llr}2.5 & \text { Quality assurance/quality control } & 12\end{array}$

$\begin{array}{llr}3.1 & \text { Water quality status and trend } & 14\end{array}$

$\begin{array}{llr}3.1 .1 & \mathrm{pH} & 18\end{array}$

\begin{tabular}{ll}
3.1 .2 & Electrical conductivity \\
\hline
\end{tabular}

$\begin{array}{ll}3.1 .3 & \text { Total suspended solids } \\ 3.1 .4 & 21\end{array}$

$\begin{array}{lll}3.1 .4 & \text { Nutrients } & 23\end{array}$

$\begin{array}{lll}3.1 .5 & \text { Dissolved oxygen } & 26\end{array}$

$\begin{array}{llr}3.1 .6 & \text { Chemical oxygen demand } & 28\end{array}$

$\begin{array}{lll}3.2 & \text { Transboundary water quality } & 30\end{array}$

$\begin{array}{lll}\text { 3.2.1 Pakse vs. Stung Treng } & 31\end{array}$

$\begin{array}{ll}\text { 3.2.2 Kaorm Samnor vs. Tan Chau } & 32\end{array}$

$\begin{array}{ll}\text { 3.2.3 Koh Thom vs. Chau Doc } & 34\end{array}$

$\begin{array}{lll}\mathbf{3 . 3} & \text { The water quality indices } & \mathbf{3 8}\end{array}$

3.3.1 The Water Quality Index for the Protection of Aquatic Life 38

3.3.2 Water Quality Index for the Protection of Human Health 39

3.3.3 Water quality indices for agricultural use 40

$\begin{array}{llr}4.1 & \text { Conclusions } & 42\end{array}$

$\begin{array}{llr}4.2 & \text { Recommendations } & 43\end{array}$ 


\section{Figures}

Figure 1. Water quality monitoring stations of the MRC WQMN in the Mekong River and its tributaries, 2018

Figure 2. Spatial variation in pH levels along the Mekong River (Stations: 1-18) and Bassac River (Stations: 18-22) as recorded in 2018

Figure 3. Temporal variation in pH levels in the Mekong River, 1985-2018

Figure 4. Spatial variation in electrical conductivity levels along the Mekong River (1-17) and Bassac River (18-22) as recorded in 2018

Figure 5. Temporal variation in electrical conductivity levels in the Mekong River as observed from 1985 to 2018

Figure 6. Spatial variation in TSS concentrations along the Mekong River (1-17) and Bassac River (18-22) as recorded in 2018

Figure 7. Temporal variation in TSS concentrations along the Mekong River as recorded from 1985 to 2018 .

Figure 8. Spatial variation in nitrate-nitrite concentrations in the Mekong River (1-17) and Bassac River (18-22), 2018

Figure 9. Temporal variation in nitrate-nitrite concentrations in the Mekong River as recorded in 1985-2018

Figure 10. Spatial variation in ammonium concentrations in the Mekong River (1-17) and Bassac River (18-22), 2018. 25

Figure 11. Temporal variation in ammonium concentrations in the Mekong River, as recorded in 1985-2018.

Figure 12. Spatial variation in total phosphorus concentrations in the Mekong River (1-17) and in the Bassac River (18-22) in 2018.

Figure 13. Temporal variation in total phosphorus concentrations in the Mekong River as observed from 2000 to 2018

Figure 14. Spatial variation in DO (mg/L) at 22 stations along the Mekong River (1-17) and the Bassac River (18-22), 2018.

Figure 15. Temporal variation in dissolved oxygen $(\mathrm{mg} / \mathrm{L})$ in the Mekong River as recorded from 1985 to 2018 .

Figure 16. Spatial variation in $\operatorname{COD~(mg/L)~at~} 22$ stations along the Mekong (1-17) and Bassac (18-22) Rivers, 2018

Figure 17. Temporal variation in COD (mg/L) in the Mekong River, from 2000 to 2018 .... 29

Figure 18. Comparisons of 2018 water quality data at Pakse and Stung Treng.................. 32

Figure 19. Comparisons of water quality data at Kaorm Samnor and Tan Chau .................34

Figure 20. Comparisons of water quality data at Koh Thom and Chau Doc..... 


\section{Tables}

Table 1. A summary of 2018 water quality monitoring stations ....................................... 4

Table 2. Water quality monitoring stations in the Mekong and Bassac Rivers numbered in sequence from upstream to downstream, and as recorded in 2018.

Table 3. Water quality parameters and their corresponding analytical methods ............ 7

Table 4. Parameters used for calculating the rating score of the Water Quality Index for the Protection of Aquatic Life, together with their target values....... 10

Table 5. Rating systems for the Water Quality Index for the Protection of Aquatic Life. 10

Table 6. Parameters used for calculating the rating score of the Water Quality Index for the Protection of Human Health and with their target values

Table 7. Rating systems for the Water Quality Index for the Protection of Human Health

Table 8. Electrical conductivity guidelines and degrees of consequence for Water Quality Index for Agricultural Use - general irrigation and paddy rice 12

Table 9. Relationships between key water quality parameters in the Mekong River as monitored by the WQMN, 1985 to 2018 .

Table 10. Comparison of water quality data in the Mekong River, between 1985-2017 and 2018

Table 11. Comparison of water quality data in the Bassac River, between 1985-2017 and 2018

Table 12. Rating of water quality of the Mekong River (from 1 to 17) and the Bassac River (from 18 to 22) according to the WQGA, 2008-2018.

Table 13. Rating of water quality of the Mekong River (from 1 to 17) and the Bassac River (from 18 to 22) for the protection of human health, 2008-2018

Table 14. Rating of water quality of the Mekong River (from 1 to 17) and the Bassac River (from 18 to 22) for agricultural use, 2008-2018 


\section{Abbreviations and acronyms}

$\begin{array}{ll}\text { BOD } & \text { Biochemical oxygen demand } \\ \text { COD } & \text { Chemical oxygen demand } \\ \text { CODMN } & \text { Chemical oxygen demand analysed using the permanganate oxidation } \\ & \text { Method } \\ \text { DO } & \text { Dissolved oxygen } \\ \text { EC } & \text { Electrical conductivity } \\ \text { EHM } & \text { Ecological Health Monitoring } \\ \text { ED } & \text { Environmental Management Division } \\ \text { HH } & \text { Human Health } \\ \text { ISO } & \text { International Organization for Standardization } \\ \text { LMB } & \text { Lower Mekong Basin } \\ \text { MC } & \text { Member Country } \\ \text { MRC } & \text { Mekong River Commission } \\ \text { MRCS } & \text { Mekong River Commission Secretariat } \\ \text { NHN } & \text { Ammonium } \\ \text { NMC } & \text { National Mekong Committee } \\ \text { NMCS } & \text { National Mekong Committee Secretariat } \\ \text { NO } & \text { Nitrate-nitrile } \\ \text { PDIES } & \text { Procedures for Data and Information Exchange and Sharing } \\ \text { PWQ } & \text { Procedures for Water Quality } \\ \text { QA } / Q C & \text { Quality Assurance/Quality Control } \\ \text { Sida } & \text { Swedish International Development Agency } \\ \text { TGWQ } & \text { Technical Guidelines for the Implementation of the Procedures for Water } \\ \text { TOTN } & \text { Quality } \\ \text { TOTP } & \text { Total nitrogen } \\ \text { TSS } & \text { Total phosphorus } \\ \text { USEPA } & \text { Total suspended solids } \\ \text { WQGA } & \text { United States Environmental Protection Agency } \\ \text { WQGH } & \text { MRC Water Quality Guidelines for the Protection of Aquatic Life } \\ \text { WQI } & \text { MRC Water Quality Guidelines for the Protection of Human Health } \\ \text { WQI } & \text { Water Quality Index } \\ \text { WQlal } & \text { Water Quality Index for Agricultural Use } \\ \text { WQl } & \text { Water Quality Index for the Protection of Aquatic Life } \\ \text { WQMN } & \text { Water Quality Index for the Protection of Human Health } \\ & \text { Water Quality Monitoring Network } \\ & \end{array}$




\section{Executive summary}

The Water Quality Monitoring Network (WQMN), which was established in 1985, has provided a continuous record of water quality in the Mekong River and its tributaries. The routine water quality monitoring under the WQMN is one of the key environmental monitoring activities at MRC, supporting the implementation of the Procedures for Water Quality (PWQ). The actual monitoring of water quality is being implemented by the designated laboratories of the Member Countries (MCs).

In 2018, the Mekong River Commission (MRC), with the assistance from MCs including Cambodia, Lao PDR, Thailand, and Viet Nam, conducted a routine monitoring of water quality in the Mekong River and its tributaries at 48 stations, of which 17 in the mainstream of the Mekong River and 31 in tributaries, of which five in the Bassac River. In 2018, in all stations, 18 parameters were measured, of which 12 are routine water quality parameters that are required to be measured for each sample month. The other six, major anions and major cations, were required to be analysed for each sample taken between April and October.

The results of the monitoring showed that the water quality in the Mekong and Bassac Rivers was still of good quality with the slight improvement compared with 2016. There was only a small number of measurements of chemical oxygen demand (COD) and dissolved oxygen (DO) that violated the MRC Water Quality Guidelines for the Protection of Human Health (WQGH) and the MRC Water Quality Guidelines for the Protection of Aquatic Life (WQGA). Most exceedances were recorded in the Delta. Of a slight concern was the DO level at Chau Doc, which violated the WQGH for all sampling occasions causing water quality for the protection of human health to be downgraded from 'good' in 2017 to 'moderate' in 2018. Using the Pearson's correlation analysis, the reduction in DO appear to be caused by the elevated levels in $\mathrm{COD}$ and $\mathrm{NO}_{32}$. Despite the potential impairment to human health, the quality was still good for the protection of aquatic life.

When compared to 2017 data, water quality of the Mekong River did not change significantly in 2018. However, historical comparisons (1985 to 2018) appear to suggest that water quality had changed significantly for many parameters including total suspended solids (TSS), which saw a reduction of yearly mean concentration from $388 \mathrm{mg} / \mathrm{L}$ in 1985 to $84.9 \mathrm{mg} / \mathrm{L}$ in 2018 . Concentrations of $\mathrm{NO}_{2-3}, \mathrm{NH}_{4}, \mathrm{COD}$ and $\mathrm{DO}$ also changed during the same period, with mean annual DO levels reduced from $7 \mathrm{mg} / \mathrm{L}$ in 1985 to $6.6 \mathrm{mg} / \mathrm{L}$ in 2018 while mean annual COD levels increased from 1.6 to $2.47 \mathrm{mg} / \mathrm{L}$ during the same period.

The assessment of the Water Quality Index for the Protection of Aquatic Life revealed that water quality in the Mekong and Bassac Rivers was still of good quality for the protection of aquatic life, with all stations rated as either 'good' or 'excellent'. Similarly, the Water Quality Index for the Protection of Human Health also reveals water quality to be of good quality for the protection of human health, with all but one station rated as either as 'good" or 'excellent' . Chau Doc was the only station rated as 'moderate' due to the reduced DO levels that violated WQGH (6 mg/L). Since there are no recorded violation of the guideline values for the Water Quality Index for General Irrigation and the Water Quality Index for Paddy Rice Irrigation, it 
can be concluded that there was no restriction for all types of agricultural use of the Mekong and Bassac Rivers water. It should be noted, however, that water quality monitoring in the Mekong Delta was undertaken during low tide, and therefore, suitability of water for agricultural use may differ during the high tide.

In term of transboundary river pollution, while analyses of water quality data at Pakse/Stung Treng, Kaorm Samnor/Tan Chau, and Koh Thom/Chau Doc reveal significant differences of levels of $\mathrm{NO}_{32}$, TOTN, and COD at these station with $\mathrm{P}$ values of less than 0.01 , the levels were still well below the WQGH and the WQGA. However, the combined levels of these pollutants appear to have affected DO levels, in particular at Chau Doc, and should be further closely monitored to ensure that any further change that may have potential effects on human health and aquatic life are detected in a timely manner and remedial action is taken. 


\section{Introduction}

\section{$2.1 \quad$ Background}

The Mekong River is the $12^{\text {th }}$ longest river in the world, at about $4,880 \mathrm{~km}$, and the $8^{\text {th }}$ largest river in terms of mean annual discharge at its mouth, at about 14,500 $\mathrm{m}^{3} / \mathrm{s}$ (Mekong River Commission, 2018). Originating in the Himalayas, the Mekong River flows southward through China, Myanmar, Lao PDR, Thailand, Cambodia and Viet Nam. With a total catchment area of $810,000 \mathrm{~km}^{2}$, the Mekong River Basin can be divided into the Upper Mekong Basin, which comprises an area in China where the Mekong is known as the Lancang River and makes up 23.2\% of the total Mekong Basin $\left(186,356 \mathrm{~km}^{2}\right.$ ), and the Lower Mekong Basin (LMB), which comprises an area downstream of the Chinese border with Lao PDR.

The LMB is functionally subdivided into four broad physiographic regions described by topography, drainage patterns and the geomorphology of river channels. These are the Northern Highlands, the Khorat Plateau, the Tonle Sap Basin and the Delta. With a total catchment area of about $623,644 \mathrm{~km}^{2}$, the LMB covers a large part of northeast Thailand, almost the entire countries of Lao PDR and Cambodia, and the southern tip of Viet Nam (Mekong River Commission, 2018).

According to the 2018 State of the Basin Report (Mekong River Commission, 2018), the Lower Mekong River is home to about 70 million people, of whom about $85 \%$ live in rural areas where many practises subsistence farming, with supplemental fish catch for livelihoods and food security. The Mekong River is also one of the most bio-diverse rivers in the world with estimated 1,148 fish species (ibid). The river's annual flood pulse continues to support a rich natural fishery and an extensive and unique wetland environment. This makes the rich ecology of the Basin extraordinarily important in terms of its contribution to livelihoods and sustainable development. As such, water quality monitoring is an integral part of detecting changes in the Mekong riverine environment and for maintaining good/acceptable water quality to promote the sustainable development of the LMB.

\subsection{Water quality monitoring network}

Recognizing that sustainable development of water resources of the LMB will not be possible without effective management of water quality, the MRC Member Countries (MCs) agreed to establish a Water Quality Monitoring Network (WQMN) with the specific objective of detecting changes in the Mekong River water quality and ensuring that preventive and remedial actions are taken if any changes are detected. The routine monitoring and reporting of water quality are the main functions of the WQMN, which was established in 1985 with a funding support from the Swedish International Development Agency (Sida). During its inception phase, Sida also provided capacity building to the MCs to monitor water quality of the Mekong River and its tributaries in their respective national boundaries. Between 1985 
and 1992, the WQMN comprised stations in Lao PDR, Thailand and Viet Nam. Cambodia later joined the WQMN in 1993, when it started to routinely monitor water quality within its national boundary.

As many as 90 water quality stations have been monitored as part of the WQMN. The peak sampling year was recorded in 2005 when 90 stations were monitored. In 2006, the MRC led by the Environment Programme, conducted a full assessment of water quality monitoring activities in the Mekong River under the WQMN. One of the outcomes of the assessment was the need to reduce the cost of the monitoring while at the same time increase its suitability. An agreement was reached for the Network to include only primary stations while the secondary stations would be monitored by individual MCs. Primary stations are those that are located in the mainstream and key tributaries of the Mekong River. Since 2006, 48 stations have been classified as 'primary stations' and were designed to detect changes and capture pressures and threats to Mekong water quality. A number of these stations were also strategically selected to detect transboundary water quality problems. In 2018, these stations continued to be monitored by the MCs as part of the WQMN. Of these 48 stations, 17 were located in the Mekong mainstream while the remaining stations (31) were located in the tributaries. Table 1 and Figure 1 in Section 12.1 details the locations of these stations.

Since its inception in 1985, the WQMN has provided a continuous record of water quality in the Mekong River and its tributaries by measuring a number of different water quality parameters at different stations. Up to 18 water quality parameters are monitored by the WQMN on a monthly basis, although during its peak years, between 1995 and 2004, up to 23 water quality parameters were monitored. These parameters comprise physical, chemical and bacteriological parameters.

The WQMN is one of the MRC's core river basin management function activities, which will be fully decentralised to the MCs by 2020. The decentralisation of the WQMN was completed for Thailand and Viet Nam in 2016 and for Cambodia in 2018. For Lao PDR, the decentralisation of the WQMN will be completed by 2025. Following decentralisation, MCs through their designated water quality laboratories will be required to finance and undertake the monitoring, sampling and analysis of Mekong water quality. At national level, each Member Country has designated a national water quality laboratory to undertake the monitoring, sampling, and analysis of Mekong water quality. The designated laboratories are responsible for undertaking routine monitoring and measurement of 19 water quality parameters (Table 3). They are also responsible for analysing, assessing and reporting water quality data on an annual basis. Their specific duties are to:

- conduct routine monthly water quality monitoring of the Mekong River and its tributaries as defined in their Terms of Reference (ToR);

- participate in the annual MRC quality assurance/quality control (QA/QC) auditing, which includes proficiency testing (PT) and internal auditing to ensure consistency and integrity of the recorded data;

- manage water quality data in accordance with the agreed format and submit the data to the Mekong River Commission Secretariat (MRCS) for validation and sharing through the MRC data portal; 
- produce and publish annual water quality data assessment report, outlining the results of water quality monitoring, analysis and assessment.

At the regional level, the MRCS is responsible to provide technical support for the monitoring of water quality and to ensure the integrity of data recorded at the national level. The MRCS also acts as a central hub for regional water quality data and provides a platform for data exchange in accordance with the Procedures for Data and Information Exchange and Sharing (PDIES) and its Technical Guidelines. In addition, the MRCS conducts regional data quality assurance, quality control and analysis, and prepares regional annual reports on water quality monitoring in the LMB.

\subsection{Objectives}

The routine water quality monitoring under the WQMN has become one of the key environmental monitoring activities implemented under the MRC Environmental Management Division (ED). Its importance is captured in both MRC Strategic Plan 2016-2020 and the Basin Development Strategy for 2016-2020. According to these documents, two major outputs are expected on an annual basis, annual water quality data and an annual water quality and data assessment report. This report has been prepared in response to these required outputs. It provides the consolidated results from the water quality monitoring activities of the MCs, focusing on the compliance of water quality data with available water quality guidelines as defined in the MRC Procedures for Water Quality and its technical guidelines. As such, the main objectives of this report are to:

- Provide the status of water quality in the Mekong River in 2018 by assessing water quality monitoring data monitored by the WQMN laboratories in 2018 and compare them with available MRC water quality guidelines;

- Identify any spatial changes observed in the water quality of the Mekong River in 2018;

- Identify any temporal changes observed in the Mekong River water quality at the 17 mainstream stations and 5 Bassac stations from the inception of their monitoring to 2018;

- Identify and discuss any transboundary water quality issue observed in 2018;

- Provide recommendations for future monitoring and continuous improvement of the water quality monitoring activities. 


\section{Materials and methods}

\subsection{Monitoring location and frequency}

Forty-eight (48) stations were monitored by the WQMN in 2018. A breakdown of the number of stations in each Member Country is presented in Table 1. As can be seen in the table, of the 48 stations monitored in 2018, 11 stations are located in Lao PDR, 8 in Thailand, 19 in Cambodia and 10 in Viet Nam.

Figure 1 illustrates their locations in the Lower Mekong Basin (17 on the Mekong River, 31 on Mekong tributaries, in which 5 on the Bassac River and 26 on the others). The detailed list of each station, code name and coordinates can be found in Table 2.

For consistency, the MCs have agreed to carry out the sampling and monitoring of water quality on a monthly basis between the $13^{\text {th }}$ and $18^{\text {th }}$ day of each month.

Table 1. A summary of 2018 water quality monitoring stations

\begin{tabular}{lccccc} 
Countries & No. of & \multirow{2}{*}{$\begin{array}{c}\text { No. on the } \\
\text { stations }\end{array}$} & Mekong River & & \multicolumn{2}{c}{ No. on tributaries } & Monitoring \\
\cline { 4 - 5 } & & 5 & $\begin{array}{c}\text { No. on the } \\
\text { Bassac River }\end{array}$ & Others & \\
\hline Lao PDR & 11 & 3 & 0 & 6 & Monthly \\
Thailand & 8 & 6 & 0 & 5 & Monthly \\
Cambodia & 19 & 3 & 3 & 10 & Monthly \\
Viet Nam & 10 & 17 & 2 & 5 & Monthly \\
\hline Total & 48 & & 5 & 26 & Monthly \\
\hline
\end{tabular}

Table 2 lists the 22 mainstream stations monitored in 2018 in geographical order, from upstream to downstream, to facilitate the analysis of water quality trends along the Mekong River mainstream. 
Table 2. Water quality monitoring stations in the Mekong and Bassac Rivers numbered in sequence from upstream to downstream, and as recorded in 2018

\begin{tabular}{|c|l|c|c|c|c|c|}
\hline $\begin{array}{c}\text { Station } \\
\text { no. }\end{array}$ & Name of station & Station ID & River & Countries & Latitude & Longitude \\
\hline 1 & Houa Khong & H010500 & Mekong River & Lao PDR & 21.5471 & 101.1598 \\
\hline 2 & Chiang Saen & H010501 & Mekong River & Thailand & 20.2674 & 100.0908 \\
\hline 3 & Luang Prabang & H011200 & Mekong River & Lao PDR & 19.9000 & 102.0000 \\
\hline 4 & Vientiane & H011901 & Mekong River & Lao PDR & 17.9281 & 102.6200 \\
\hline 5 & Nakhon Phanom & H013101 & Mekong River & Thailand & 17.4250 & 104.7744 \\
\hline 6 & Savannakhet & H013401 & Mekong River & Lao PDR & 16.5583 & 104.7522 \\
\hline 7 & Khong Chiam & H013801 & Mekong River & Thailand & 15.3255 & 105.4937 \\
\hline 8 & Pakse & H013900 & Mekong River & Lao PDR & 15.1206 & 105.7837 \\
\hline 9 & Stung Treng & H014501 & Mekong River & Cambodia & 13.5450 & 106.0164 \\
\hline 10 & Kratie & $\mathrm{H} 014901$ & Mekong River & Cambodia & 12.4777 & 106.0150 \\
\hline 11 & Kampong Cham & $\mathrm{H} 019802$ & Mekong River & Cambodia & 11.9942 & 105.4667 \\
\hline 12 & Chrouy Changvar & $\mathrm{H} 019801$ & Mekong River & Cambodia & 11.5861 & 104.9407 \\
\hline 13 & Neak Loung & $\mathrm{H} 019806$ & Mekong River & Cambodia & 11.2580 & 105.2793 \\
\hline 14 & Kaorm Samnor & $\mathrm{H} 019807$ & Mekong River & Cambodia & 11.0679 & 105.2086 \\
\hline 15 & Tan Chau & $\mathrm{H} 019803$ & Mekong River & Viet Nam & 10.9079 & 105.1835 \\
\hline 16 & My Thuan & $\mathrm{H} 019804$ & Mekong River & Viet Nam & 10.2725 & 105.9100 \\
\hline 17 & My Tho & $\mathrm{H} 019805$ & Mekong River & Viet Nam & 10.3430 & 106.3505 \\
\hline 18 & Takhmao & $\mathrm{H} 033401$ & Bassac River & Cambodia & 11.4785 & 104.9530 \\
\hline 19 & Koh Khel & $\mathrm{H} 033402$ & Bassac River & Cambodia & 11.2676 & 105.0292 \\
\hline 20 & Koh Thom & $\mathrm{H} 033403$ & Bassac River & Cambodia & 11.1054 & 105.0678 \\
\hline 21 & Chau Doc & $\mathrm{H} 039801$ & Bassac River & Viet Nam & 10.9552 & 105.0867 \\
\hline 22 & Can Tho & $\mathrm{H} 039803$ & Bassac River & Viet Nam & 10.0580 & 105.7977 \\
\hline
\end{tabular}




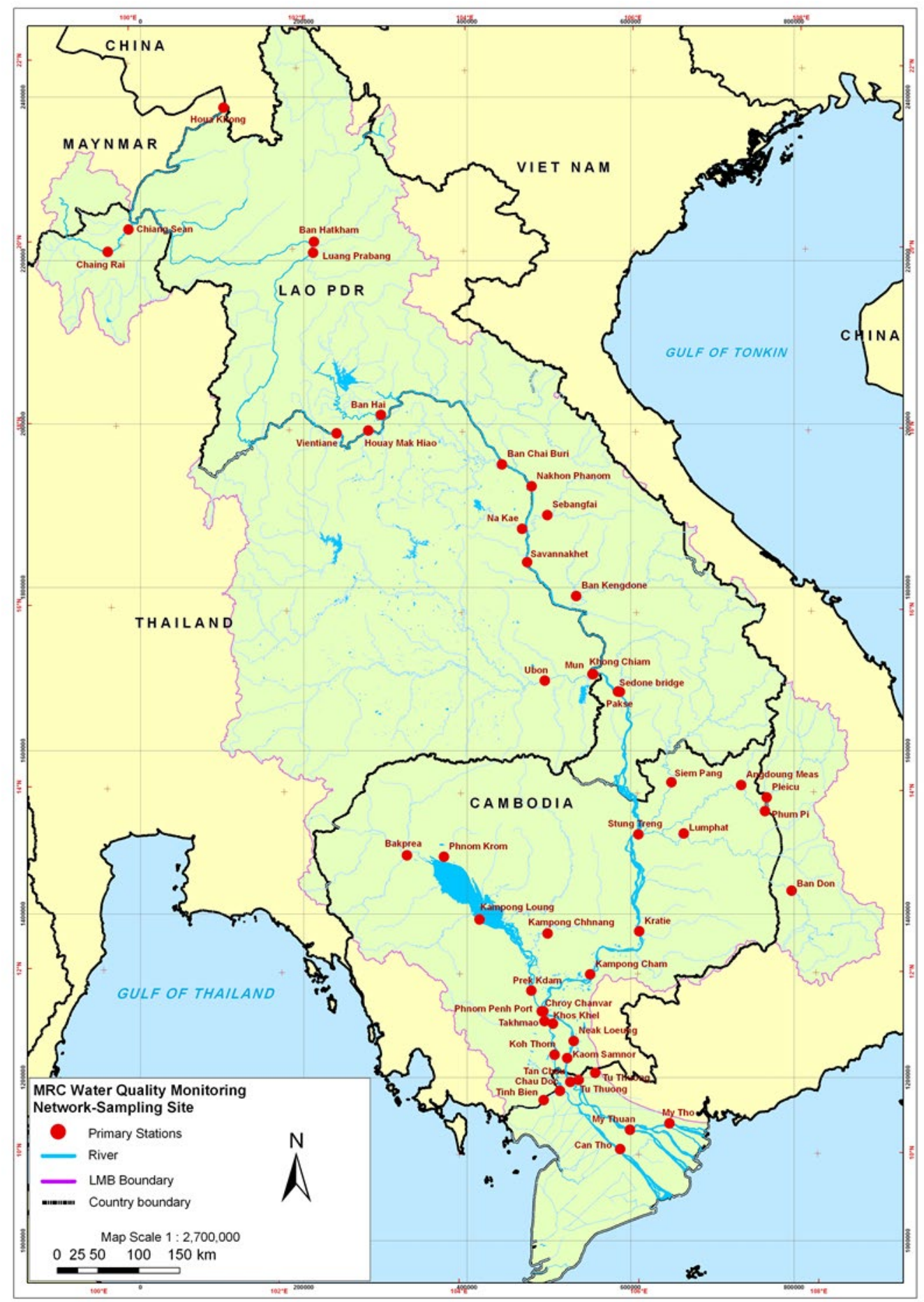

Figure 1. Water quality monitoring stations of the MRC WQMN in the Mekong River and its tributaries, 2018

\subsection{Sampling techniques}

In an effort to standardize the sampling techniques, in 2018, the MRC continued to work with the designated laboratories of the MCs to identify appropriate sampling techniques for 
collecting water samples. Through consultations, it was agreed that the water sampling, sample preservation, sample transportation and storage, would be carried out in accordance with methods listed in the Technical Guidelines for the PWQ (TGWQ), which have been prepared in accordance with the $22^{\text {nd }}$ edition of the Standard Methods for the Examination of Water and Wastewater (Rice et al., 2012) or in accordance with national standards complying with the requirements of method validation of ISO/IEC 17025-2005.

Specifically, the designated laboratories are required to:

- collect water samples using the simple surface grab technique at the middle of the stream where free flowing water is observable;

- collect water samples at about 30 to $50 \mathrm{~cm}$ under the surface of the stream;

- if in-situ measurement is not possible, immediately preserve samples collected with proper preservative agents (i.e. sulphuric acid for nutrients measurement) and store in a cooler to prevent further breakdown of chemicals and biological contents; and

- analyse all water samples within the recommended holding time.

All designated laboratories of the MRC WQMN are required to adhere to the MRC QA/QC procedures outlined in the TGWQ, which were developed in accordance with ISO/IEC 170252005 and personnel safety procedures when collecting water samples and measuring water quality parameters.

\subsection{Laboratory analytical methods}

Since its inception in 1985, the Water Quality Monitoring Network has provided data on water quality in the Mekong River and its selected tributaries by measuring a number of different water quality parameters. At its peak, the network (Table 2) provided a measurement of 23 water quality parameters. However, in 2018, 19 water quality parameters were measured by the MRC WQMN (Table 3). Of the 19 parameters measured in 2018, 13 are routine water quality parameters that are required to be measured for each sample month. The other six, major anions and major cations, are required to be analysed for each sample taken between April and October.

In addition to providing a list of parameters measured by the MRC WQMN, Table 3 provides a list of recommended analytical methods used for measuring water quality parameters, as mentioned in Section 2.2.

Table 3. Water quality parameters and their corresponding analytical methods

\begin{tabular}{|l|l|}
\hline \multicolumn{1}{|c|}{ Analytical parameter } & \multicolumn{1}{c|}{ Recommended analytical methods } \\
\hline Temperature & $2550-\mathrm{Temp} / \mathrm{SM}$ \\
\hline $\mathrm{pH}$ & $4500-\mathrm{H}^{+} / \mathrm{SM}$ \\
\hline Electrical conductivity & $2510-\mathrm{EC} / \mathrm{SM}$ \\
\hline Alkalinity/acidity & $2320-\mathrm{A} / \mathrm{SM}$ \\
\hline Dissolved oxygen (DO) & $4500-\mathrm{O} / \mathrm{SM}$ \\
\hline Chemical oxygen demand (COD) & Permanganate oxidation \\
\hline Total phosphorous (T-P) & $4500-\mathrm{P} / \mathrm{SM}$ \\
\hline
\end{tabular}




\begin{tabular}{|l|l|}
\hline Total Nitrogen (T-N) & $4500-\mathrm{N} / \mathrm{SM}$ \\
\hline Ammonium (NH4-N) & $4500-\mathrm{NH} 4 / \mathrm{SM}$ \\
\hline Total nitrite and nitrate (NO2-3-N) & $4500-\mathrm{NO} 2-3 / \mathrm{SM}$ \\
\hline Faecal coliform & $9221-\mathrm{Faecal}$ coliform group/SM \\
\hline Total suspended solids & $2540-\mathrm{D}-\mathrm{TSS}-\mathrm{SM}$ \\
\hline Calcium (Ca) & $3500-\mathrm{Ca}-\mathrm{B} / \mathrm{SM}$ \\
\hline Magnesium (Mg) & $3500-\mathrm{Mg}-\mathrm{B} / \mathrm{SM}$ \\
\hline Sodium (Na) & $3500-\mathrm{Na}-\mathrm{B} / \mathrm{SM}$ \\
\hline Potassium (K) & $3500-\mathrm{K}-\mathrm{B} / \mathrm{SM}$ \\
\hline Sulphate (SO4) & $4500-\mathrm{SO} 4-\mathrm{E} / \mathrm{SM}$ \\
\hline Chloride (Cl) & $4500-\mathrm{Cl} / \mathrm{SM}$ \\
\hline BOD $_{5}$ & $5210-\mathrm{BOD}_{5} / \mathrm{SM}$ \\
\hline
\end{tabular}

\subsection{Data analysis}

\subsubsection{Status and trends}

The overall status of the Mekong water quality in 2008 was examined by applying descriptive statistics such annual maximum, mean, and minimum to summarise data series of key water quality parameters collected in 2018 along the Mekong River. Descriptive statistics are commonly used to analyse and compare various aspects of water quality data (He et al., 2009; Johnson et al., 2009; Ai et al., 2015; Gu et al., 2019), as they provide quick snapshots of data series that are generally large and not event distributed in nature (Fisher and Marshall, 2009; Lee, 2020). These values were compared to those of the WQGH (Chapter 1 of the TGWQ) and for the Protection of Aquatic Life (Chapter 2 of the TGWQ) to identify any exceeded values that need special attention.

Variations of key water quality parameters were assessed spatially and temporally. Spatial variation was carried out for 2018 to examine the differences in levels of key water quality parameters along the Mekong and Bassac Rivers. Pearson correlation analyses (Benesty et al., 2009) were performed to establish relationships between these parameters and to help explained the variation observed.

Temporal analyses of water quality data from the period of 1985 to 2018 were carried out for key parameters using a combination of box-and-whisker plots and seasonal Mann-Kendall trend test (SKM) (Chang, 2008; Ly et al., 2020). Known as a non-parametric method, SKM has the advantage for its capabilities in handling environmental monitoring data series similar to those found in the water quality data series and have been used to detect trends for data series that exhibit seasonality, missing data point and non-normal distributed (Fu and Wang, 2012; Ly et al., 2020).

In addition to these statistical analyses box-and-whisker plots were used to help support the characterization of water quality data, for both spatial and temporal analyses. Box-andwhisker plots are often used to analyse variation and central tendency of data. It is a useful 
statistical tool, which can be used to explore a dataset and show key statistics associated with it. In particular, when using box-and-whisker plots the following key statistical information can be drawn (Fu and Wang, 2012):

- median value of the dataset;

- upper quartile and lower quartile or the median of all data above and below the median, respectively;

- upper and lower extremes or the maximum and minimum values of the dataset (excluding outliers), respectively.

\subsubsection{Transboundary water quality}

Transboundary water quality was assessed for six stations located at or near national borders of the MCs. Water quality data comparison and assessment were made for Pakse versus Stung Treng; Kaorm Samnor versus Tan Chau; and Koh Thom versus Chau Doc. Comparisons were made for two stations using key pollutant monitoring data in 2018 for the stations closest upstream and downstream of the national border, respectively. Box-and-whisker plots, using the statistical software package SPSS 23 , were used to characterise water quality data. Any observed differences between the upstream and downstream stations were tested using an independent t-test, to determine whether the differences observed are statistically significant.

\subsubsection{Water quality indices}

Another way to assess water quality in the Mekong River is through the use of the MRC Water Quality Indices, which combine the results of several parameters into one overall value describing the water quality. In 2013, the MRC MCs adopted three water quality indices taking into account requirements under Chapters 1 and 2 of the TGWQ and available water quality guidelines of the MCs. These indices include:

- Water Quality Index for the Protection of Aquatic Life (WQI $\left.\left.\right|_{a l}\right)$;

- Water Quality Index for the Protection of Human Health (WQI ${ }_{h h}$ );

- Water Quality Index for Agricultural Use, which is divided into two categories (WQag): general irrigation and paddy rice.

\section{The Water Quality Index for the Protection of Aquatic Life}

The Water Quality Index for the Protection of Aquatic Life is calculated using Equation 2.1. The Index was developed as an open-ended index, which would allow more parameters to be added once data become available (Campbell, 2014). In this annual water quality report, only six parameters are included. These parameters, together with their target values, are listed in Table 4. The classification system for the Water Quality Index for the Protection of Aquatic Life is summarized in Table 5. 


$$
W Q I=\frac{\sum_{i=1}^{n} p_{i}}{M} \times 10
$$

Equation 2.1

Where,

" $p_{i}$ " is the points scored on sample day i. If each parameter listed in Table 4 meets its respective target value in Tables $2-6$, one point is scored; otherwise, the score is zero;

" $n$ " is the number of samples from the station in the year;

" $\mathrm{M}$ " is the maximum possible score for the measured parameters in the year;

Table 4. Parameters used for calculating the rating score of the Water Quality Index for the Protection of Aquatic Life, together with their target values

\begin{tabular}{|l|l|}
\hline Parameters & Target values \\
\hline $\mathrm{pH}$ & $6-9$ \\
\hline $\mathrm{EC}(\mathrm{ms} / \mathrm{m})$ & $<150$ \\
\hline $\mathrm{NH}_{3}(\mathrm{mg} / \mathrm{L})$ & 0.1 \\
\hline $\mathrm{DO}(\mathrm{mg} / \mathrm{L})$ & $\geq 5$ \\
\hline $\mathrm{NO}_{2-3}-\mathrm{N}(\mathrm{mg} / \mathrm{L})$ & 0.5 \\
\hline $\mathrm{T}-\mathrm{P}(\mathrm{mg} / \mathrm{L})$ & 0.13 \\
\hline
\end{tabular}

Table 5. Rating systems for the Water Quality Index for the Protection of Aquatic Life

\begin{tabular}{|l|l|}
\hline Rating Score & Class \\
\hline $9.5 \leq \mathrm{WQI} \leq 10$ & A: High Quality \\
\hline $8 \leq \mathrm{WQI}<9.5$ & B: Good Quality \\
\hline $6.5 \leq \mathrm{WQI}<8$ & C: Moderate Quality \\
\hline $4.5 \leq \mathrm{WQI}<6.5$ & D: Poor Quality \\
\hline $\mathrm{WQI}<4.5$ & E: Very Poor Quality \\
\hline
\end{tabular}

\section{Water Quality Index for the Protection of Human Health}

With the finalization of Chapter 1 (Guidelines for the Protection of Human Health) of the Technical Guidelines for the Implementation of the Procedures for Water Quality (TGWQ), the MRC MCs have agreed to include human health $(\mathrm{HH})$ in the analysis of water quality of the Mekong River. To assist in communicating water quality information concerning the protection of human health, water quality indices and classification systems were developed, focusing on human health acceptability and $\mathrm{HH}$ risk.

The Human Health Acceptability Index utilizes parameters of indirect impact, as identified by the Water Quality Index for Human Health $(\mathrm{HH})$, while the Human Health Risk Index utilizes direct impact parameters. The rating score for both indices can be calculated using Equation 
2.2, which is based on the Canadian Water Quality Index (CCME, 2001). It should be noted that since the monitoring of direct impact parameters has not commenced, MCs have agreed to adopt only the Human Health Acceptability Index. The list of the approved parameters to be included in the calculation of the rating score for the human health acceptability index, together with their target values are listed in Table 6 . The classification system for the Water Quality Index for the Protection of Human Health - Human Acceptability Index is summarized in Table 7.

$$
W Q I=100-\left(\frac{\sqrt{F_{1}^{2}+F_{2}^{2}+F_{3}^{2}}}{1.732}\right)
$$

Where, $F_{1}$ is the percentage of parameters, which exceed the guidelines and can be calculated by Equation 2.3.

$$
F_{1}=\left(\frac{\# \text { of failed parameters }}{\text { Total \# of parameters }}\right)
$$

Equation 2.3

$F_{2}$ is the percentage of individual tests for each parameter that exceed the guideline and can be calculated by Equation 2.4.

$$
F_{2}=\left(\frac{\# \text { of failed tests }}{\text { Total } \# \text { of tests }}\right)
$$

$\mathrm{F}_{3}$ is the extent to which the failed test exceeds the target value and can be calculated using Equation 2.5.

$$
F_{3}=\left(\frac{n s e}{0.01 n s e+0.01}\right)
$$

Where $n s e$ is the sum of excursions and can be calculated using Equation 2.6.

$$
\text { nse }=\left(\frac{\text { Eexcursion }}{\text { Total } \# \text { of tests }}\right)
$$

Equation 2.6

The excursion is calculated by Equation 2.7.

$$
\text { excursion }=\left(\frac{\text { failed test value }}{\text { guideline value }}\right)-1
$$

Table 6. Parameters used for calculating the rating score of the Water Quality Index for the Protection of Human Health and with their target values

\begin{tabular}{|l|l|}
\hline Parameters & Target values \\
\hline $\mathrm{pH}$ & $6-9$ \\
\hline $\mathrm{EC}(\mathrm{mS} / \mathrm{m})$ & $<150$ \\
\hline $\mathrm{NH}_{3}(\mathrm{mg} / \mathrm{L})$ & 0.5 \\
\hline $\mathrm{DO}(\mathrm{mg} / \mathrm{L})$ & $\geq 4$ \\
\hline $\mathrm{NO}_{2-3}-\mathrm{N}(\mathrm{mg} / \mathrm{L})$ & 5 \\
\hline $\left.\mathrm{COD}^{*} \mathrm{mg} / \mathrm{L}\right)$ & 5 \\
\hline $\mathrm{BOD}^{*}(\mathrm{mg} / \mathrm{L})$ & 4 \\
\hline
\end{tabular}


*Due to the required holding time for Biochemical oxygen demand (BOD), MCs have agreed to only monitor BOD at stations where samples can be analysed within the required holding time of less than 48 hours. Therefore, $B O D$ was only included for the stations where data are available.

Table 7. Rating systems for the Water Quality Index for the Protection of Human Health

\begin{tabular}{|l|l|l|}
\hline Rating Score & Class & Description \\
\hline $\begin{array}{l}95 \leq \mathrm{WQI} \\
\leq 100\end{array}$ & A: Excellent Quality & $\begin{array}{l}\text { All measurements are within objectives virtually } \\
\text { all of the time }\end{array}$ \\
\hline $80 \leq \mathrm{WQI}<95$ & B: Good Quality & Conditions rarely depart from desirable levels \\
\hline $65 \leq \mathrm{WQI}<80$ & C: Moderate Quality & $\begin{array}{l}\text { Conditions sometimes depart from desirable } \\
\text { levels }\end{array}$ \\
\hline $45 \leq \mathrm{WQI}<65$ & D: Poor Quality & Conditions often depart from desirable levels \\
\hline WQI $<45$ & E: Very Poor Quality & Conditions usually depart from desirable levels \\
\hline
\end{tabular}

\section{Water Quality Index for Agricultural Use}

Another index adopted by the MRC MCs as a means for communicating water quality monitoring information to the public is the Water Quality Index for Agricultural Use, focusing on water quality for general irrigation and paddy rice. The indices for general irrigation and paddy rice are calculated based on the MRC Water Quality Guidelines for Salinity (electrical conductivity). The electrical conductivity (EC) guidelines, together with the degree of consequence, for the indices for general irrigation and paddy rice irrigation are outlined in Table 8.

Table 8. Electrical conductivity guidelines and degrees of consequence for Water Quality Index for Agricultural Use - general irrigation and paddy rice

\begin{tabular}{|l|l|l|l|l|}
\hline \multirow{2}{*}{ Irrigation raw water } & \multirow{4}{*}{ Unit } & \multicolumn{3}{|l|}{ Degree of consequence* } \\
\cline { 3 - 5 } & & $\begin{array}{l}\text { None } \\
\text { (A) }\end{array}$ & $\begin{array}{l}\text { Some } \\
\text { (B) }\end{array}$ & $\begin{array}{l}\text { Severe } \\
\text { (C) }\end{array}$ \\
\hline Electrical conductivity & \multicolumn{5}{|l|}{} \\
\hline General irrigation & $\mathrm{m}^{\mathrm{s}} / \mathrm{m}$ & $<70$ & $70-300$ & $>300$ \\
\hline Paddy rice irrigation & $\mathrm{m} / \mathrm{m}$ & $<200$ & $200-480$ & $>480$ \\
\hline
\end{tabular}

Note:

$*$ None $=100 \%$ yield $;$ some $=50-90 \%$ yield; severe $=<50 \%$ yield

\subsection{Quality assurance/quality control}

Recognizing the need to improve the quality, precision and accuracy of the water quality data, all designated laboratories of the MRC WQMN were requested to jointly implement a quality assurance and quality control (QA/QC) test for water sampling, preservation, transportation, 
and analysis from 2004. The goal of the implementation of the QA/QC procedures is to ensure that the designated laboratories carry out their routine water quality monitoring activities in accordance with the TGWQ and international standard ISO/IEC 17025-2005. To date, of the four designated laboratories of the MRC WQMN, the laboratories in Lao PDR and Viet Nam have received ISO/IEC 17025-2005 certification. The certifications were given by the Bureau of Accreditation, Directorate for Standards and Quality of Viet Nam.

Other designated laboratories, while not ISO/IEC 17025-2005 certified, have rigorously implemented the MRC WQMN QA/QC in Sampling and Laboratory Work or national QA/QC procedures that meet the requirements of the ISO/IEC 17025-2005. The MRC QA/QC procedure calls for the designated laboratories to:

- Be well prepared for each sampling event, have a sampling plan with clear sampling objectives and ensure sampling teams are equipped with appropriate sampling and safety equipment and preservative chemical reagents.

- Apply quality control during sampling, which consists of taking duplicate samples and field blanks for certain parameters.

- Analyse all water samples within recommended holding times.

- Conduct routine maintenance and calibration of all measurement equipment.

- Conduct a data analysis using control chart and reliability score testing using an ion balance test.

- Archive raw data and any important information relating to the results of the analysis in order to make it possible to trace all data and reconfirm the results of the analysis. 


\section{Results}

\subsection{Water quality status and trend}

Water quality data from the WQMN has allowed for relationships between key water quality parameters to be established (Table 9). These relationships are important in facilitating the understanding of instream behaviours of key water quality parameters. For example, nitratenitrite $\left(\mathrm{NO}_{32} \mathrm{~N}\right)$ levels in the Mekong appear to be positively correlated with TOTN and chemical oxygen demand (COD) while negatively correlated with ammonium $\left(\mathrm{NH}_{4} \mathrm{~N}\right)$, total phosphorus (TOTP), and dissolved oxygen (DO); i.e. as TOTN and COD levels increased, so did the levels of $\mathrm{NO}_{32}$. Conversely, the decrease in $\mathrm{NO}_{32} \mathrm{~N}$ levels were due to the increase in $\mathrm{NH}_{4} \mathrm{~N}$, TOTP and DO levels.

Key water quality parameters monitored in stations along the Mekong and Bassac Rivers are analysed spatially and temporally to reflect the status of water quality of the LMB in 2018 and the trend of water quality from 2000 to 2018. In addition, a comparison of the maximum, mean, and minimum values of key water quality parameters between 1985-2017 and 2018 are presented in Tables 10 and to see if there is any parameter exceeding the WQGH and the WQGA. Four of the nine key parameters monitored in 2018 violated the MRC water quality guidelines listed in Chapters 1 or 2 of the TGWQ at one point or another in stations along the Mekong River (Table 10). These parameters were: (i) pH with minimum value of 5.4 compared to the recommended guidelines of 6 to 9; (ii) EC with values ranging from 4.6 to $50.7 \mathrm{mS} / \mathrm{m}$ compared to the recommended guidelines of $70-150 \mathrm{mS} / \mathrm{m}$; (iii) DO with a minimum value of $4.57 \mathrm{mg} / \mathrm{l}$, which did not meet the required guidelines for both the protection of human health ( $6 \mathrm{mg} / \mathrm{L}$ ) and aquatic life (5 mg/L); and (iv) COD with maximum value of $6.48 \mathrm{mg} / \mathrm{L}$, which exceeded the WQGH ( $5 \mathrm{mg} / \mathrm{L}$ ). Along the Bassac River, three key parameters were recorded to have violated the same guidelines. These parameters included: EC, where all recorded values fell outside the guidelines range of $70-150 \mathrm{mS} / \mathrm{m}$; DO with a minimum value of 3.1 $\mathrm{mg} / \mathrm{L}$, which did not reach the recommended WQGH $(6 \mathrm{mg} / \mathrm{L})$ and the WQGA $(5 \mathrm{mg} / \mathrm{L})$; and COD, which exceeded the guidelines for the protection of human health $(5 \mathrm{mg} / \mathrm{L})$, with the maximum recorded value of $5.6 \mathrm{mg} / \mathrm{L}$. 
Table 9. Relationships between key water quality parameters in the Mekong River as monitored by the WQMN, 1985 to 2018

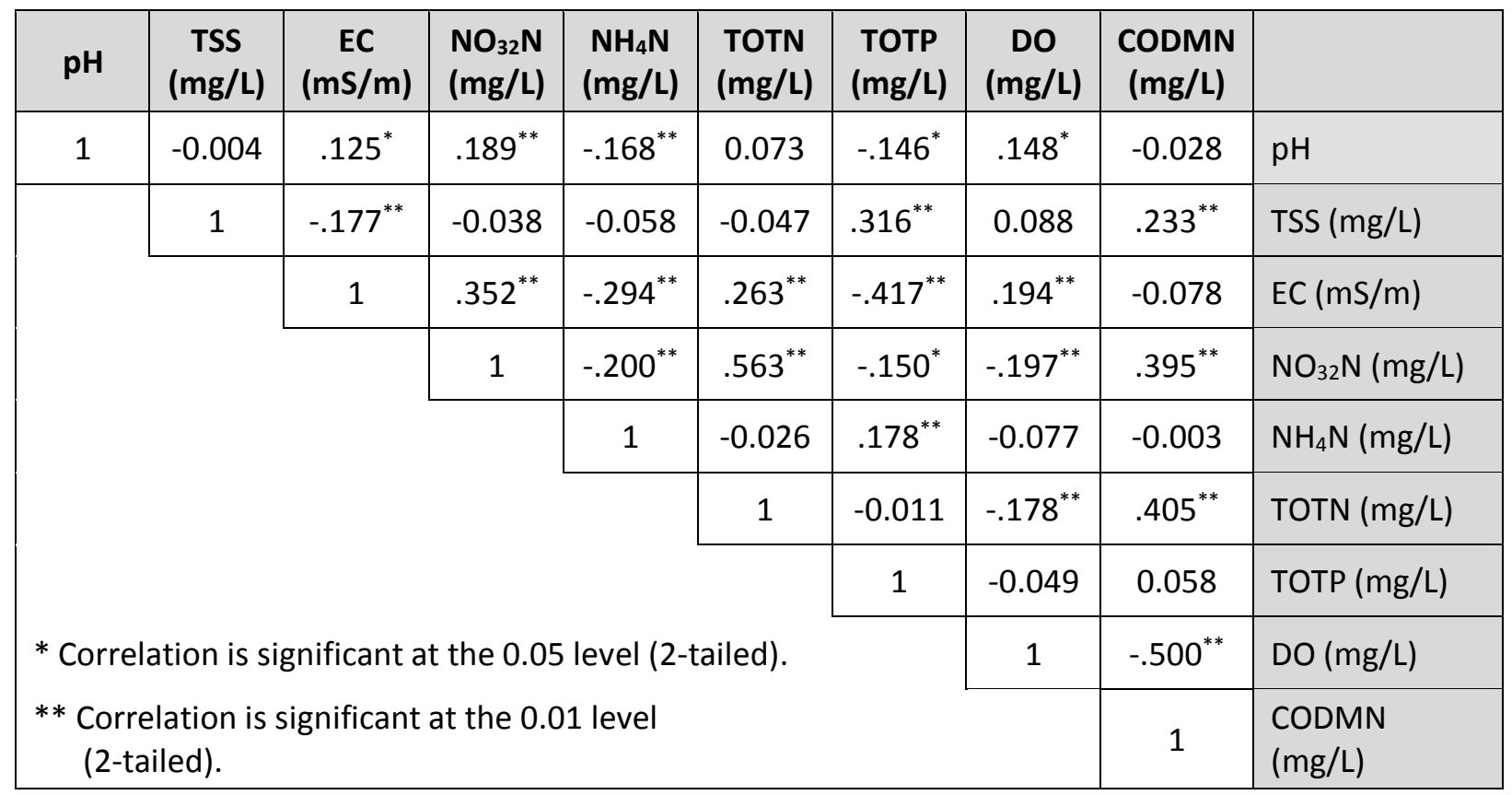


Table 10. Comparison of water quality data in the Mekong River, between 1985-2017 and 2018

\begin{tabular}{|c|c|c|c|c|c|c|c|c|c|c|c|}
\hline \multirow[b]{2}{*}{ Parameters } & \multirow[b]{2}{*}{ Unit } & \multicolumn{2}{|c|}{ Water Quality Guidelines } & \multicolumn{4}{|c|}{ 1985-2017 } & \multicolumn{4}{|c|}{2018} \\
\hline & & $\begin{array}{l}\text { Protection of } \\
\text { Human } \\
\text { Health } \\
\text { (WQGH) }\end{array}$ & $\begin{array}{l}\text { Protection of } \\
\text { Aquatic Life } \\
\text { (WQGA) }\end{array}$ & Max & Mean & Min & Stdev & Max & Mean & Min & Stdev \\
\hline $\mathrm{pH}$ & - & $6-9$ & $6-9$ & 9.9 & 7.5 & 3.8 & 0.5 & 8.5 & 7.4 & $5.4^{*}$ & 0.5 \\
\hline TSS & $\mathrm{mg} / \mathrm{L}$ & - & - & 5716.0 & 147.1 & 0.1 & 256.2 & 518.0 & 84.9 & 2.8 & 91.9 \\
\hline EC & $\mathrm{mS} / \mathrm{m}$ & $70-150$ & - & 841.0 & 20.7 & 1.2 & 27.7 & 50.7 & 19.8 & 4.6 & 6.6 \\
\hline $\mathrm{NO}_{32} \mathrm{~N}$ & $\mathrm{mg} / \mathrm{L}$ & 5 & 5 & 1.42 & 0.24 & 0.00 & 0.17 & 1.12 & 0.31 & 0.03 & 0.19 \\
\hline $\mathrm{NH}_{4} \mathrm{~N}$ & $\mathrm{mg} / \mathrm{L}$ & - & - & 2.99 & 0.05 & 0.00 & 0.11 & 0.36 & 0.07 & 0.00 & 0.07 \\
\hline TOTN & $\mathrm{mg} / \mathrm{L}$ & - & - & 4.89 & 0.58 & 0.00 & 0.39 & 3.56 & 0.56 & 0.11 & 0.32 \\
\hline TOTP & $\mathrm{mg} / \mathrm{L}$ & - & - & 2.20 & 0.10 & 0.00 & 0.12 & 0.43 & 0.09 & 0.00 & 0.08 \\
\hline DO & $\mathrm{mg} / \mathrm{L}$ & $\geq 6$ & $>5$ & 13.85 & 7.22 & 2.25 & 1.09 & 11.43 & 6.60 & 4.57 & 1.11 \\
\hline CODMN & $\mathrm{mg} / \mathrm{L}$ & 5 & - & 65.00 & 2.25 & 0.00 & 1.97 & 6.48 & 2.47 & 0.13 & 1.50 \\
\hline
\end{tabular}

Note:

*Yellow colour marks non-compliance with WQGH or WQGA. 
Table 11. Comparison of water quality data in the Bassac River, between 1985-2017 and 2018

\begin{tabular}{|c|c|c|c|c|c|c|c|c|c|c|c|}
\hline \multirow[b]{2}{*}{ Parameters } & \multirow[b]{2}{*}{ Unit } & \multicolumn{2}{|c|}{ Water Quality Guidelines } & \multicolumn{4}{|c|}{ 1985-2017 } & \multicolumn{4}{|c|}{2018} \\
\hline & & $\begin{array}{c}\text { Protection of } \\
\text { Human } \\
\text { Health } \\
\text { (WQGH) }\end{array}$ & $\begin{array}{l}\text { Protection of } \\
\text { Aquatic Life } \\
\text { (WQGA) }\end{array}$ & Max & Mean & Min & Stdev & Max & Mean & Min & Stdev \\
\hline $\mathrm{pH}$ & - & $6-9$ & $6-9$ & 8.0 & 7.1 & 6.2 & 0.4 & 8.1 & 7.2 & 6.6 & 0.3 \\
\hline TSS & $\mathrm{mg} / \mathrm{L}$ & - & - & 279.0 & 58.0 & 4.5 & 49.6 & 218.9 & 46.8 & 2.9 & 42.1 \\
\hline EC & $\mathrm{mS} / \mathrm{m}$ & $70-150$ & - & $27.5^{*}$ & 14.7 & 7.5 & 4.8 & 24.8 & 15.8 & 9.8 & 5.1 \\
\hline $\mathrm{NO}_{32} \mathrm{~N}$ & $\mathrm{mg} / \mathrm{L}$ & 5 & 5 & 1.10 & 0.31 & 0.02 & 0.21 & 1.09 & 0.33 & 0.03 & 0.25 \\
\hline $\mathrm{NH}_{4} \mathrm{~N}$ & $\mathrm{mg} / \mathrm{L}$ & - & - & 0.63 & 0.11 & 0.00 & 0.11 & 0.42 & 0.10 & 0.01 & 0.07 \\
\hline TOTN & $\mathrm{mg} / \mathrm{L}$ & - & - & 3.45 & 0.75 & 0.15 & 0.49 & 1.52 & 0.59 & 0.25 & 0.29 \\
\hline TOTP & $\mathrm{mg} / \mathrm{L}$ & - & - & 1.24 & 0.15 & 0.00 & 0.14 & 0.32 & 0.12 & 0.01 & 0.07 \\
\hline DO & $\mathrm{mg} / \mathrm{L}$ & $\geq 6$ & $>5$ & 9.3 & 6.3 & 1.8 & 1.1 & 7.5 & 5.7 & 3.1 & 0.8 \\
\hline CODMN & $\mathrm{mg} / \mathrm{L}$ & 5 & - & 5.9 & 2.7 & 0.3 & 1.2 & 5.6 & 2.9 & 0.4 & 1.4 \\
\hline
\end{tabular}

Note:

*Yellow colour marks non-compliance with the WQGH or the WQGA. 


\subsection{1 pH}

In aquatic ecosystems, $\mathrm{pH}$ can affect many chemical and biological processes. This is because $\mathrm{pH}$ affects the solubility and availability of nutrients and heavy metals in water (USEPA, 2012b). At extremely low $\mathrm{pH}$, some toxic compounds and elements from sediments may be released into the water where they can be taken up by aquatic animals or plants, and ultimately by humans through direct contact and/or human consumption of aquatic animals or plants (USEPA, 2012b). Additionally, changes in pH can also influence the availability of trace elements, iron and nutrients, such as phosphate and ammonia in water. As such, $\mathrm{pH}$ is one of the key water quality parameters monitored by the MRC Water Quality Monitoring Network. In 2018, the WQMN continued to monitor pH levels at all 17 Mekong and 5 Bassac water quality monitoring stations.

Recognizing the importance of $\mathrm{pH}$ on the Mekong riverine environment, the MCs have agreed to establish the technical water quality guidelines for $\mathrm{pH}$ levels in the Mekong River and its tributaries to protect human health and aquatic life. The overall goal is to achieve the MRC water quality - i.e. to maintain acceptable/good water quality to promote the sustainable development of the Mekong River Basin.

Compared to the recommended guidelines, the results of 2018 monitoring revealed that, while all $\mathrm{pH}$ values measured along the Bassac River were within the upper and lower target values of the WQGH and the WQGA ( $\mathrm{pH}$ values of 6 to 9 for both the protection of human health and aquatic life), $1.5 \%$ of $\mathrm{pH}$ values measured along the Mekong River were lower, the same recommended target values (Tables 10 and 11).

In 2018, the $\mathrm{pH}$ values recorded in the Mekong ranged from 5.4 to 8.5 , with the minimum $\mathrm{pH}$ value recorded at Luang Prabang Station in Lao PDR, on 17 July 2018, and the maximum value measured in Houa Khong Station, on 16 August 2018. The average pH value of the Mekong River in 2018 was recorded at about 7.4, which was similar to the average values recorded between 1985 and 2017 (pH of 7.5).

The spatial trend for $\mathrm{pH}$ in the Mekong and Bassac Rivers is shown in Figure 2. Other than the level observed in Luang Prabang $(5.4 \leq \mathrm{pH} \leq 7.9)$, $\mathrm{pH}$ levels did not greatly vary from station to station. Results of the temporal analysis of pH data from 1985 to 2018 are shown in Figure 3. Figure 3 shows that the overall pH levels decreased slightly from 1985 to 2018. In 1985, the average $\mathrm{pH}$ value was recorded at 7.8 , while in 2018 , the average $\mathrm{pH}$ value was recorded at 7.3. 

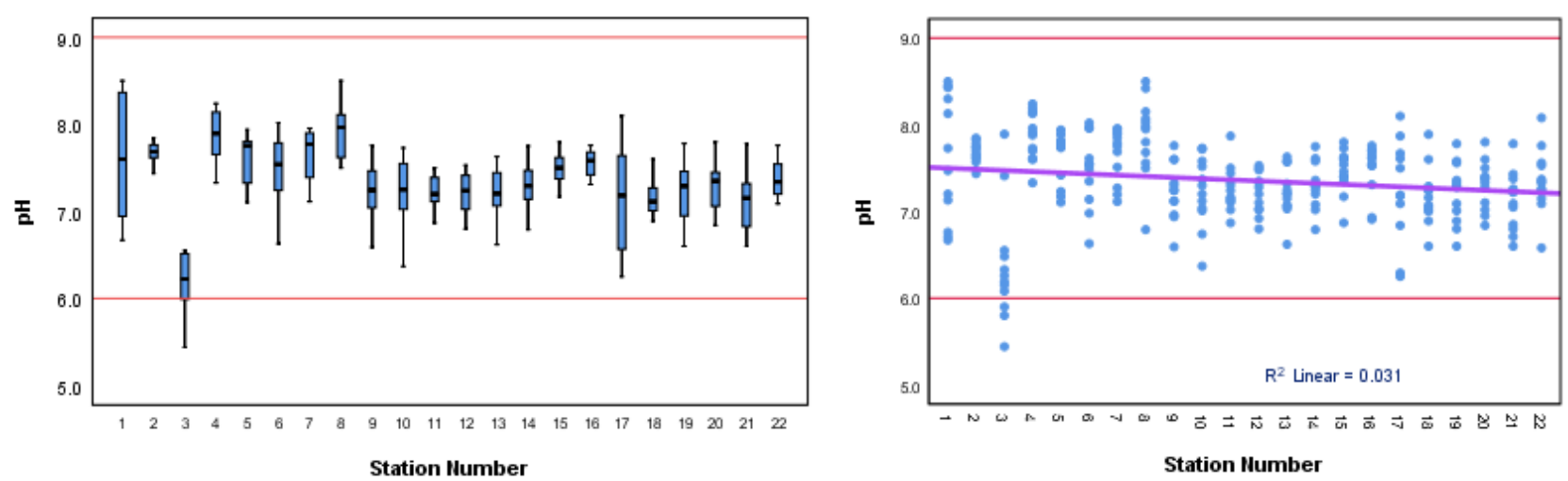

Figure 2. Spatial variation in $\mathrm{pH}$ levels along the Mekong River (Stations: 1-17) and Bassac River (Stations: 18-22) as recorded in 2018 and illustrated using box-and-whisker plot (left) and dot plot (right)

Note:

The horizontal lines at 6.0 and 9.0 represent the lower and upper pH limits of the WQGH and the WQGA, respectively.
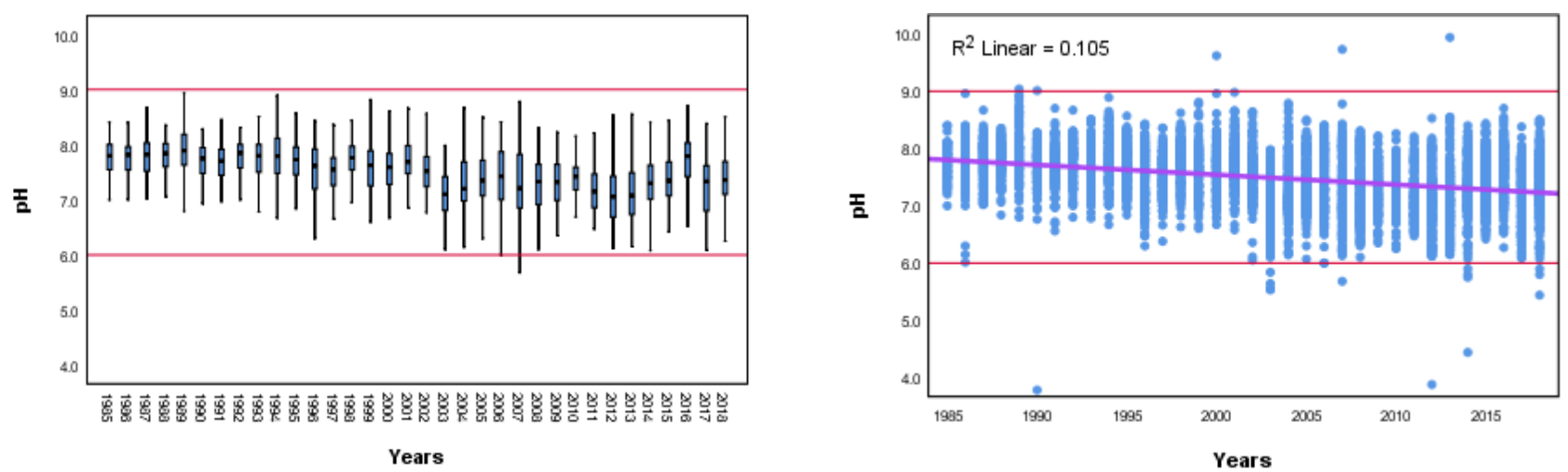

Figure 3. Temporal variation in pH levels in the Mekong River, 1985-2018, and illustrated using boxand-whisker plot (left) and dot plot (right)

Note:

The horizontal lines at 6.0 and 9.0 represent the lower and upper pH limits of the WQGH and the WQGA, respectively.

\subsubsection{Electrical conductivity}

Electrical conductivity $(\mathrm{EC})$ is another useful water quality indicator monitored by the MRC WQMN. It provides a valuable baseline that has been used to identify any emerging effects of development on water quality in the Mekong River. Under normal circumstance and in areas that are not affected by saline intrusion, the Mekong and Bassac Rivers, similar to other water bodies, have constant ranges of conductivity, and therefore, any sudden and significant change in EC can be an indicator of water pollution. Wetzel (2001) states that pollution from 
agricultural runoff or sewage leaks can increase EC levels, while USEPA (2014) reported that a spill of organic compound such as oil can reduce them.

In 2018, all EC levels were recorded to fall outside the recommended range of the WQGHof 70-150 ms/m. It should be noted, however, that the Mekong River mainstream and Bassac River are naturally a low-salinity river with EC values rarely exceeded $50 \mathrm{mS} / \mathrm{m}$. High EC had been observed in the Delta (Viet Nam's stations) during high tide due to the intrusion of sea water, and had been recorded with a maximum value of $841.0 \mathrm{mS} / \mathrm{m}$. This maximum value was recorded at My Tho Water Quality Monitoring Station in April 1998. In 2018, all samplings in the Delta, for both the Mekong River and the Bassac Rivers, were carried out during low tide, which may explain the low levels of EC recorded.

Spatial and temporal trends for EC in the Mekong and Bassac Rivers are illustrated in Figures 4 and 5, respectively. The Mekong and Bassac Rivers can generally be characterised as rivers with low conductivity values, with average historical values from 1985 to 2017 of about 20.7 and $14.7 \mathrm{mS} / \mathrm{m}$, respectively (Tables 10 and 11). ${ }^{1}$ In 2018, ECs of the Mekong River were not different from the historical values with the mean value of $19.8 \mathrm{mS} / \mathrm{m}$. For the Bassac River, the conductivity continued to be relatively low, with values ranging from 9.8 to $24.8 \mathrm{mS} / \mathrm{m}$, and the mean value was $15.8 \mathrm{mS} / \mathrm{m}$, which is similar to the historical values (Table 11).

Spatially, as shown in Figure 4, in 2018, conductivity levels in the Mekong River were not very different among stations. The highest value was recorded in the upper part of the river. For example, Houa Khong Station (1), the uppermost station of the MRC WQMN, reported EC values ranging from 20.1 to $32.8 \mathrm{mS} / \mathrm{m}$, with an average value of $27.3 \mathrm{mS} / \mathrm{m}$. At My Tho Station (17) - the last station in the Mekong River before the river enters the East Sea - reported values ranged from 13.6 to $50.7 \mathrm{mS} / \mathrm{m}$, with an average value of $22.5 \mathrm{mS} / \mathrm{m}$. Chrouy Changvar (12), the station located in the middle part of the Lower Mekong River, reported values ranging from 10.3 to $23.7 \mathrm{mS} / \mathrm{m}$, with an average value of $17.3 \mathrm{mS} / \mathrm{m}$.
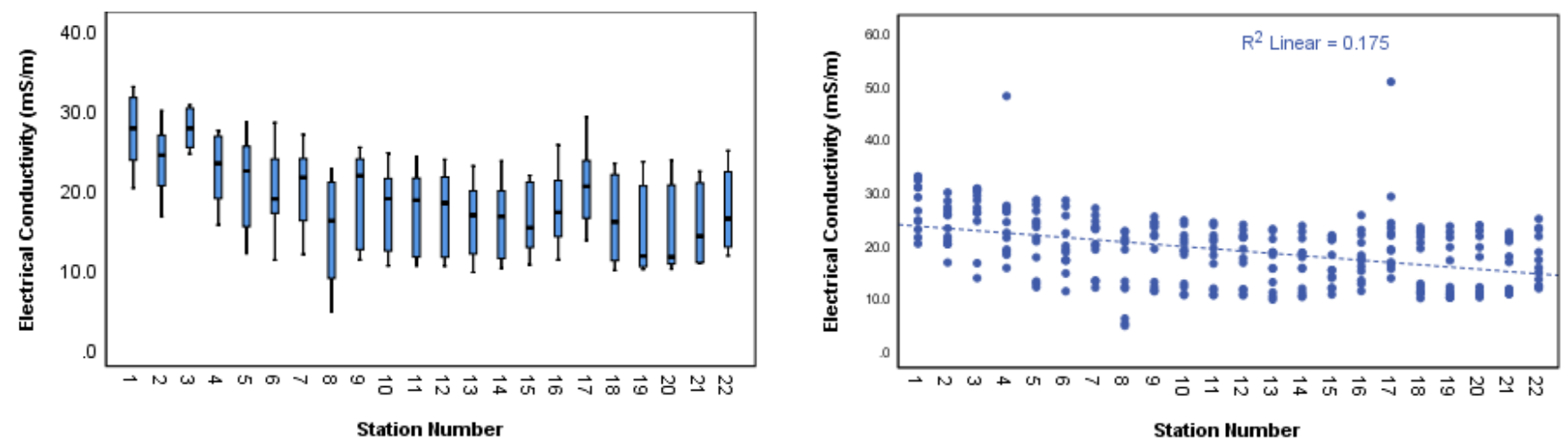

Figure 4. Spatial variation in electrical conductivity levels along the Mekong River (1-17) and Bassac River (18-22) as recorded in 2018 and illustrated using box-and-whisker plot (left) and dot plot (right)

\footnotetext{
${ }^{1}$ These average values are based on measurements taken during low tide. Electrical conductivity values for stations located in the Delta generally can reach up to more than 5,000 ms/m during high tide.
} 
Note:

The horizontal lines at 70 and 150 represent the lower and upper EC limits of the WQGH.
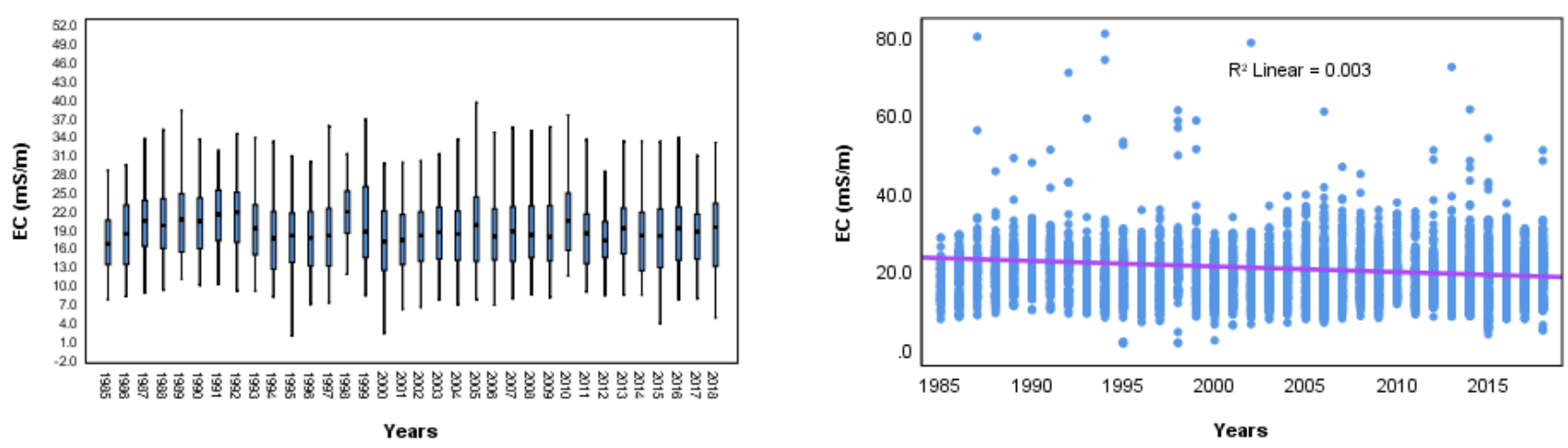

Figure 5. Temporal variation in electrical conductivity levels in the Mekong River as observed from 1985 to 2018 and illustrated using box-and-whisker plot (left) and dot plot (right)

Note:

The horizontal lines at 70 and 150 represent the lower and upper EC limits of the WQGH.

\subsubsection{Total suspended solids}

In the Mekong River, total suspended solids (TSS) are influenced by both natural and anthropogenic activities in the Basin, including urban runoff, industrial effluents, and natural and/or human induced (i.e. agriculture, forestry or construction) soil erosion (Herngren et al., 2005; Chen and Chang, 2014; Ly et al., 2020). The method used by the MRC WQMN to sample TSS does not reflect the sediment concentration in the entire water column, ${ }^{2}$ but currently provides an indication of long-term trends in sediment content in the Mekong River.

In 2018, the TSS concentrations observed along the Mekong River continued to be highly variable, with values ranging from 2.8 to $518.0 \mathrm{mg} / \mathrm{L}$. The average TSS concentration was about $84.9 \mathrm{mg} / \mathrm{L}$ (Table 10). TSS concentrations along the Bassac River, however, were less variable than the range observed along the Mekong River. Along the Bassac River, TSS concentrations ranged from 2.9 to $218.9 \mathrm{mg} / \mathrm{L}$, with an average value of $46.8 \mathrm{mg} / \mathrm{L}$ (Table 11).

Spatially, the highest TSS levels were observed in the upper part of the Lower Mekong River. TSS levels at stations located in this part of the river were also highly variable, as can be seen in Figure 6. The maximum TSS concentration of $518 \mathrm{mg} / \mathrm{L}$ recorded in 2018 was observed at Luang Prabang, Lao PDR (3) in August 2018.

For both the Mekong and Bassac Rivers, the lowest TSS concentrations were observed during the dry season (November to April). In general, the Lower Mekong River receives very little to no rainfall during the dry season, which causes the dry season TSS concentrations to be lower than those generally observed during the wet season. Along the Mekong River, the average

\footnotetext{
${ }^{2}$ Water samples are taken approximately $30 \mathrm{~cm}$ below the water surface.
} 
dry season TSS concentration was recorded at about $48.2 \mathrm{mg} / \mathrm{L}$. The highest dry season concentration for TSS was recorded at $88.5 \mathrm{mg} / \mathrm{L}$ at Houa Khong Water Quality Monitoring Station, Lao PDR (1) in November 2018, while the lowest concentration was recorded at 4.6 $\mathrm{mg} / \mathrm{L}$ at Kratie Water Quality Monitoring Station, Cambodia (10) in February 2018.

During the wet season, the average concentration for the Mekong River was recorded at about $138 \mathrm{mg} / \mathrm{L}$, with values ranging from 19.3 to $518 \mathrm{mg} / \mathrm{L}$. The lowest wet season TSS concentration was recorded in Chiang Sean, Thailand (2) in May 2018, while the highest concentration was recorded at Luang Prabang, Lao PDR (3) in August 2018.

The temporal analysis of data from 1985 to 2018 suggests that TSS levels in the Mekong River decreased since 2000 (Figure 7). The average TSS concentration in the Mekong River in 1985 was measured at about $388 \mathrm{mg} / \mathrm{L}$, whereas in 2018, the average monthly concentration for TSS was measured at about $84.9 \mathrm{mg} / \mathrm{L}$. This figure is slightly lower than the figure recorded in 2017, where the average TSS concentration for the Mekong River as recorded at $94.6 \mathrm{mg} / \mathrm{L}$.
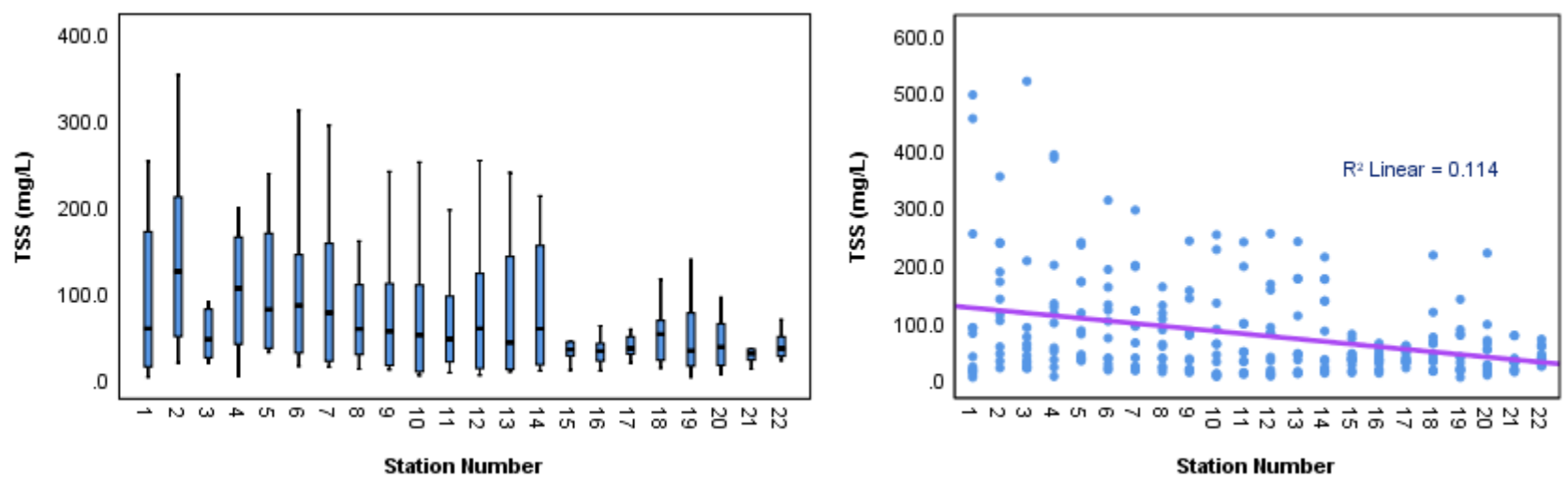

Figure 6. Spatial variation in TSS concentrations along the Mekong River (1-17) and Bassac River (1822) as recorded in 2018 and illustrated using box-and-whisker plot (left) and dot plot (right) 


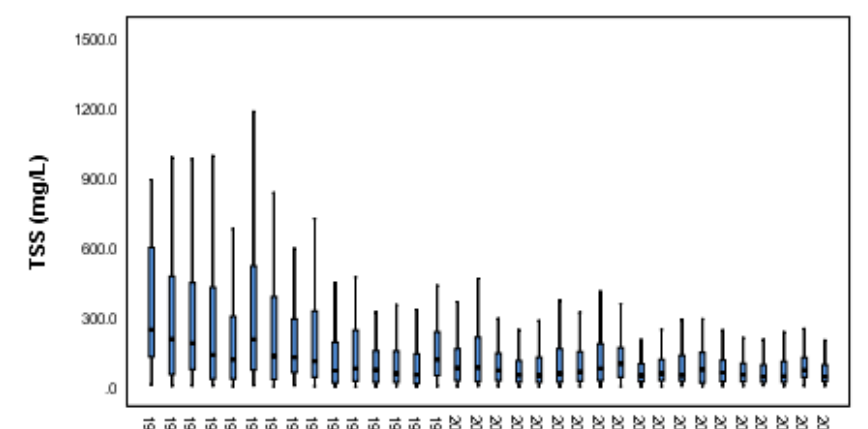

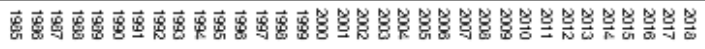

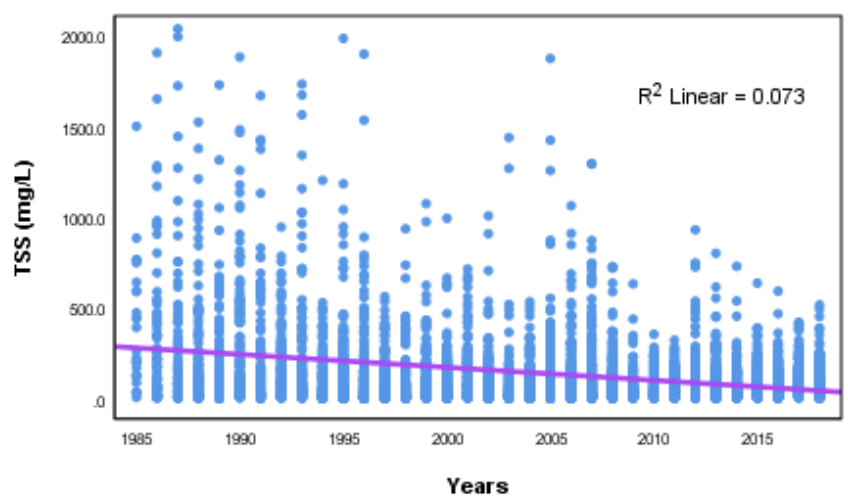

Years

Figure 7. Temporal variation in TSS concentrations along the Mekong River as recorded from 1985 to 2018 and illustrated using box-and-whisker plot (left) and dot plot (right)

\subsubsection{Nutrients}

\section{Nitrogen}

The MRC WQMN designated laboratories continued to monitor concentrations of nitritenitrate, ammonium and total phosphorus as part of nutrient monitoring in 2018. Concentrations of nutrients at all mainstream stations in the Mekong River and Bassac River remained well below the WQGH and the WQGA (Table 10).

The spatial analysis of water quality data shows that in 2018, nitrate-nitrite concentrations were highly variable in a number of stations, including Houa Khong (1) and Savannakhet (6), which are located in the upper and middle part of the river, respectively, and My Tho (17), Chau Doc (21), and Can Tho (22), which are located in the Mekong Delta. At these stations, the highest concentration of nitrate-nitrite were observed at My Tho station in April 2018 at $1.12 \mathrm{mg} / \mathrm{L}$, which was well below the MRC Water Quality Guidelines for the Protection of Human Health and Aquatic Life (5 mg/L) (Figure 8 ).

Temporal analysis of nitrate-nitrite concentration from 1985 to 2018 reveals that nitratenitrite concentrations in the Mekong River remained relatively constant (Figure 9). For the Mekong River, nitrate-nitrite concentrations in 2018 (average value of 0.31) were similar to those recorded in 2017 (average value of $0.32 \mathrm{mg} / \mathrm{L}$ ), but slightly increased when compared to the concentrations recorded in 1985 (average 0.2). However, these values are well below the target values for both WQHGH and WQGA of $5 \mathrm{mg} / \mathrm{L}$. 

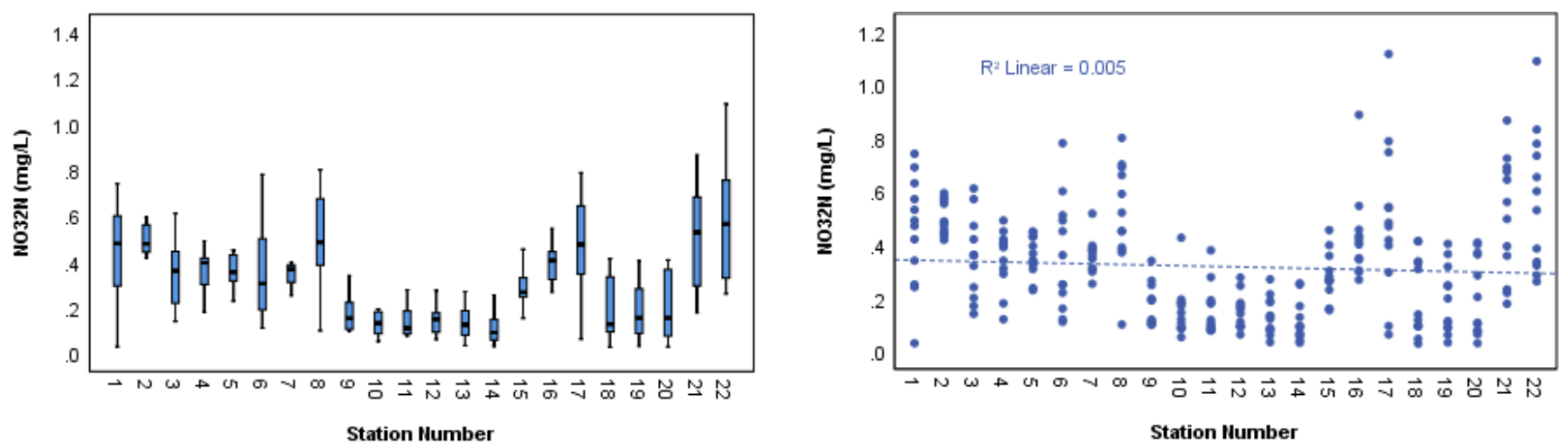

Figure 8. Spatial variation in nitrate-nitrite concentrations in the Mekong River (1-17) and Bassac River (18-22), 2018 and illustrated using box-and-whisker plot (left) and dot plot (right)
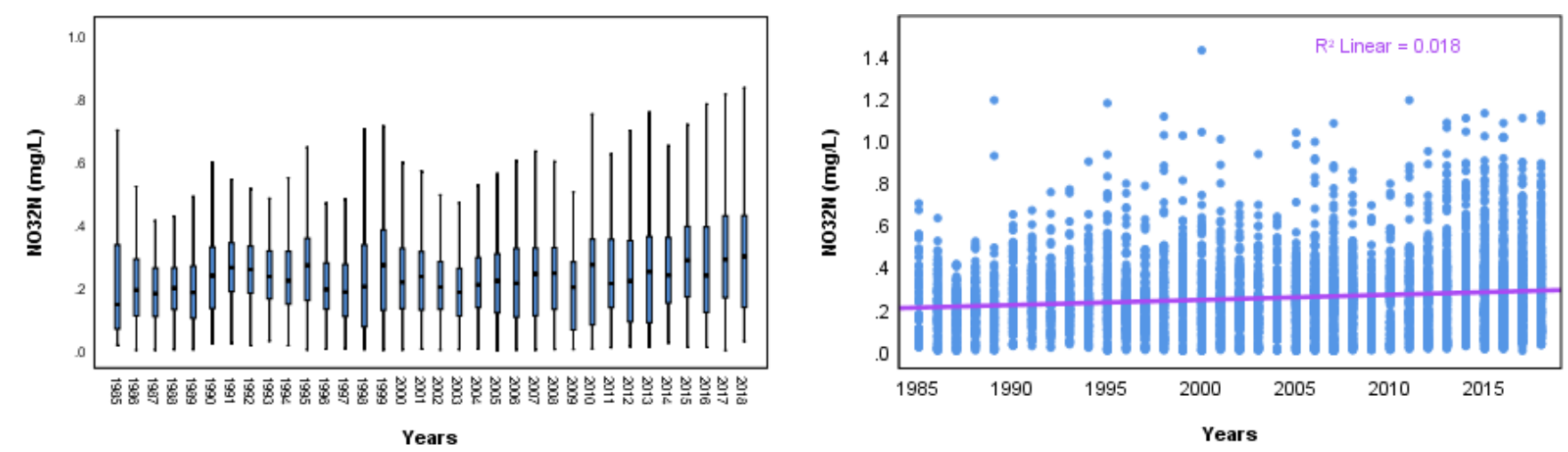

Figure 9. Temporal variation in nitrate-nitrite concentrations in the Mekong River as recorded in 1985-2018 and illustrated using box-and-whisker plot (left) and dot plot (right)

Spatial analysis shows that the concentrations of ammonium along the stations in lower part of the basin including stations located along the Mekong and Bassac River were highly variable compared to those located in the upper part of the basin (Figure 10). In 2018, the highest ammonium was measured at Kampong Cham (11) $(0.36 \mathrm{mg} / \mathrm{L})$ and Koh Khel (19) $(0.42 \mathrm{mg} / \mathrm{L})$, for the Mekong and Bassac Rivers, respectively. At these stations, the average ammonium concentrations were recorded at $0.05 \mathrm{mg} / \mathrm{L}$ (Kampong Cham) and $0.12 \mathrm{mg} / \mathrm{L}$ (Koh Khel). In comparison, the threshold value used for calculating Water Quality Index for Human Impact is $0.05 \mathrm{mg} / \mathrm{L}$.

A temporal analysis of data from 1985 to 2018 for the Mekong River reveals that overall ammonium concentrations remain relatively constant (Figure 11). The average yearly ammonium concentrations in the Mekong River increased slightly from $0.03 \mathrm{mg} / \mathrm{L}$ in 1985 to about $0.07 \mathrm{mg} / \mathrm{L}$ in 2018 . 

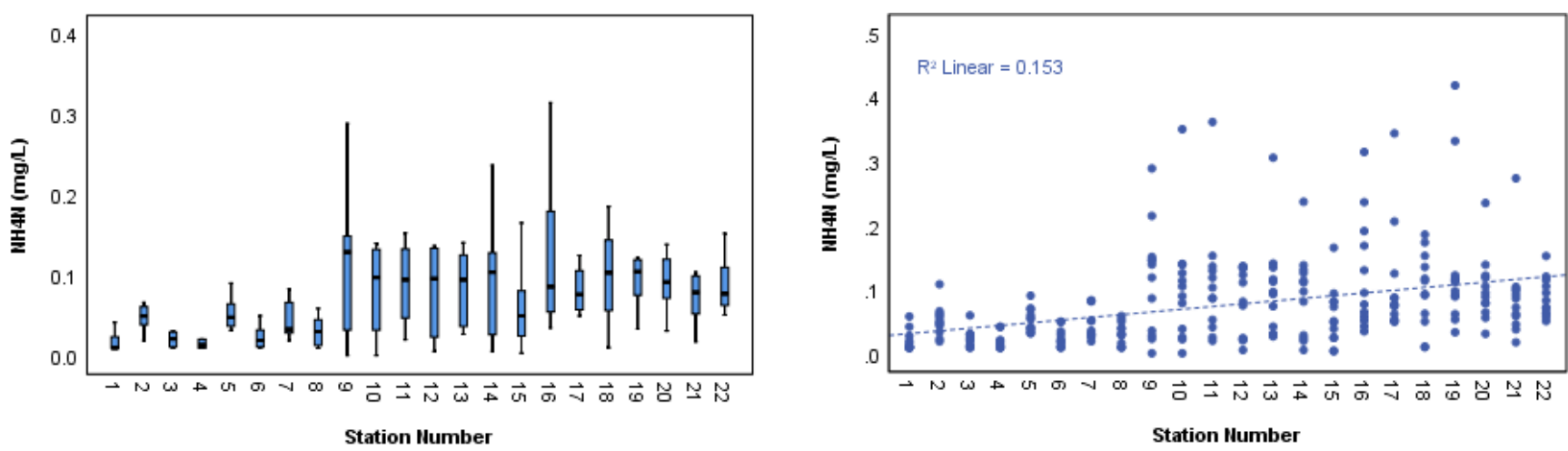

Figure 10. Spatial variation in ammonium concentrations in the Mekong River (1-17) and Bassac River (18-22), 2018 and illustrated using box-and-whisker plot (left) and dot plot (right)
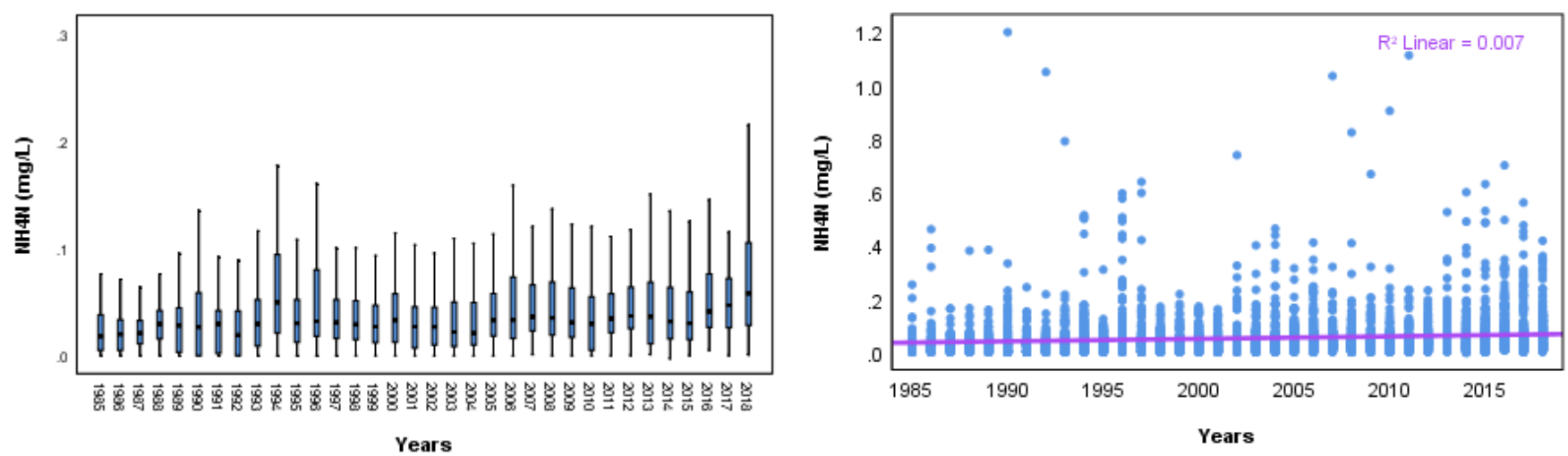

Figure 11. Temporal variation in ammonium concentrations in the Mekong River, as recorded in 1985-2018 and illustrated using box-and-whisker plot (left) and dot plot (right)

\section{Phosphorus}

In 2018, total phosphorus concentrations were highly variable among stations (Figure 12). While the highest concentrations of total phosphorus were recorded at Houa Khong station (1) with the value of $0.43 \mathrm{mg} / \mathrm{L}$, the lowest was observed at $0.04 \mathrm{mg} / \mathrm{L}$ at Kratie (10). Compared to the threshold value used for calculating the Water Quality Index for the Protection of Aquatic Life ( $0.13 \mathrm{mg} / \mathrm{L}$ ) (Table 4), elevated concentrations of total phosphorus were observed at all but three monitoring stations on at least one monitoring occasion. The three monitoring stations were Luang Prabang (3), Vientiane (4), and Pakse (8) where in April no exceedance was recorded. In comparison, four stations recorded no concentration of greater than or equal to $0.13 \mathrm{mg} / \mathrm{L}$ in 2017.

In the Bassac River, the highest total phosphorus concentrations were recorded at stations in Cambodia was measured at Takhmao station (18) $(0.29 \mathrm{mg} / \mathrm{L})$, Koh Khel (19) $(0.29 \mathrm{mg} / \mathrm{L})$, and Koh Thom (20) $(0.32 \mathrm{mg} / \mathrm{L})$. Elevated concentrations of total phosphorus were observed at all monitoring stations in Bassac River on at least one monitoring occasion. 

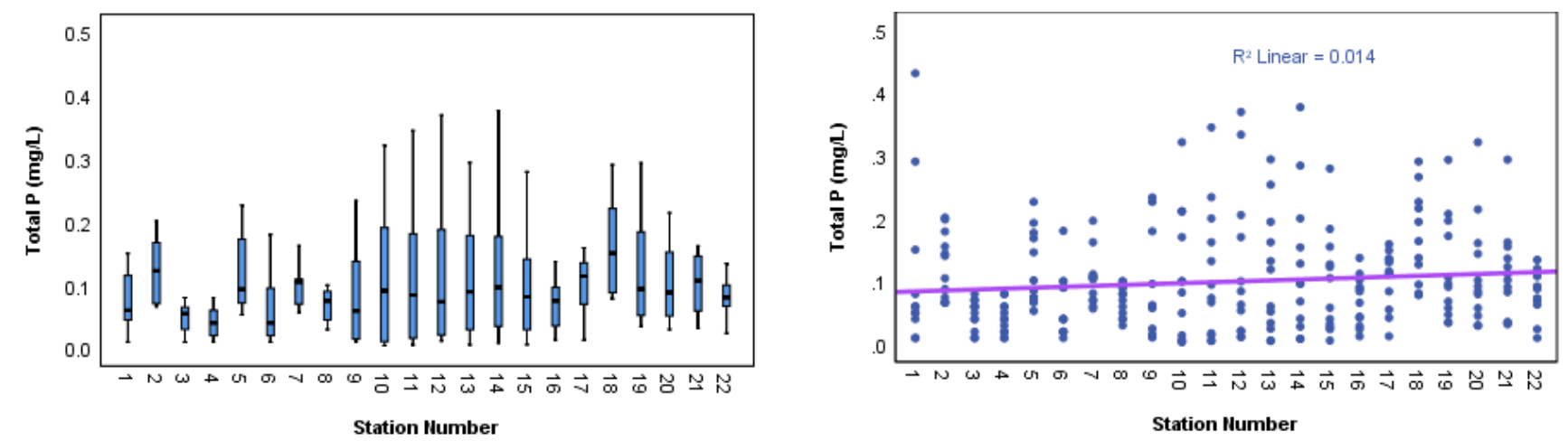

Figure 12. Spatial variation in total phosphorus concentrations in the Mekong River (1-17) and in the Bassac River (18-22) in 2018 and illustrated using box-and-whisker plot (left) and dot plot (right)

Between 1985 and 2018, total phosphorus concentrations in the Mekong River increased slightly, from mean concentration of about $0.1 \mathrm{mg} / \mathrm{L}$ in 1985 and $0.058 \mathrm{mg} / \mathrm{L}$ in 1986 to about $0.09 \mathrm{mg} / \mathrm{L}$ in 2018 (Figure 13). Increased human activities such as agricultural runoff and municipal wastewater discharge in the downstream part of the basin were the likely reason for the trend. However, the average concentration of total phosphorous in 2018 was similar to 2017 (0.1 mg/L).
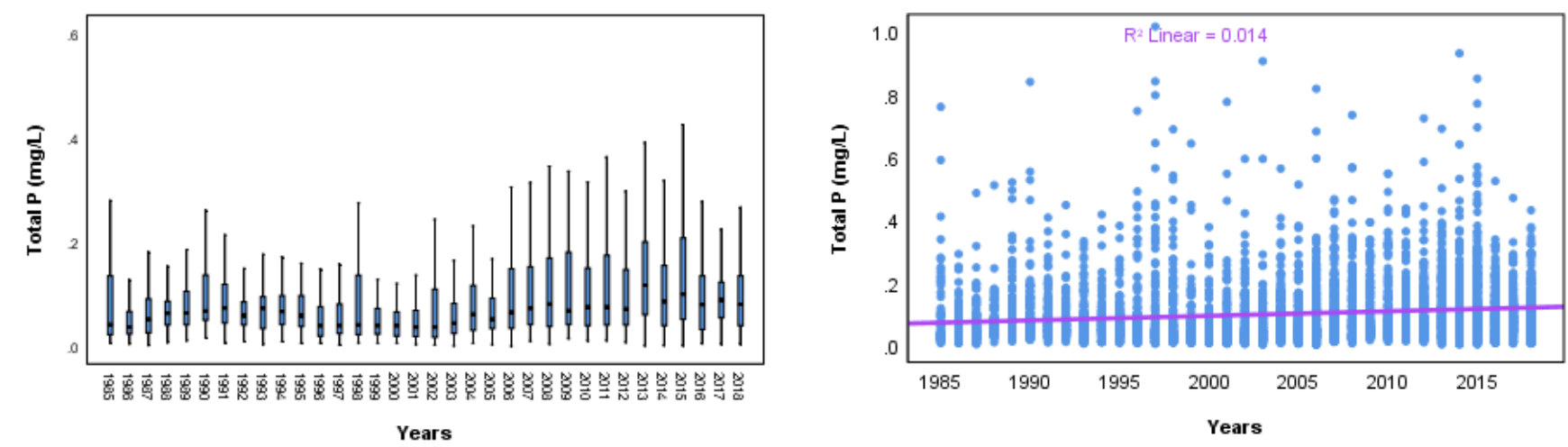

Figure 13. Temporal variation in total phosphorus concentrations in the Mekong River as observed from 2000 to 2018 and illustrated using box-and-whisker plot (left) and dot plot (right)

\subsubsection{Dissolved oxygen}

Dissolved oxygen (DO) is one of the key water quality parameters monitored routinely by the MRC Water Quality Monitoring Network. To maintain acceptable/good water quality, an adequate concentration of DO is necessary, because oxygen is required for all life forms, including those that live in a river ecosystem. Prolonged reduction in DO level can lead to fish kill, and can affect other water quality indicators, including biochemical and aesthetic indicators such as odour, clarity, and taste (USEPA, 2012a). Recognizing that DO is an integral component for determining the water quality of the Mekong River, the MRC MCs have jointly 
established target values for the protection of human health (WQGH) ( $\geq 6 \mathrm{mg} / \mathrm{L}$ ) and aquatic life (WQGA) (> $5 \mathrm{mg} / \mathrm{L})$.

The 2018 DO data were compared with the MRC Water Quality Guidelines for the Protection of Human Health and Aquatic Life. Of the WQGH water quality monitoring stations located in the Mekong and Bassac Rivers, 14 stations recorded DO levels below the MRC Water Quality Guidelines for the Protection of Human Health at least once in the year $(\leq 6 \mathrm{mg} / \mathrm{L})$. In comparison, 15 stations recorded DO levels below the WQGH in 2017. This indicates a slight improvement in the concentrations of DO in the mainstream of the Mekong and Bassac Rivers.

In addition to violating the WQGH, eight stations recorded DO levels lower than the WQGA (i.e. $<5 \mathrm{mg} / \mathrm{L}$ ), at least one time. These stations are all located in the Delta areas below Phnom Penh.
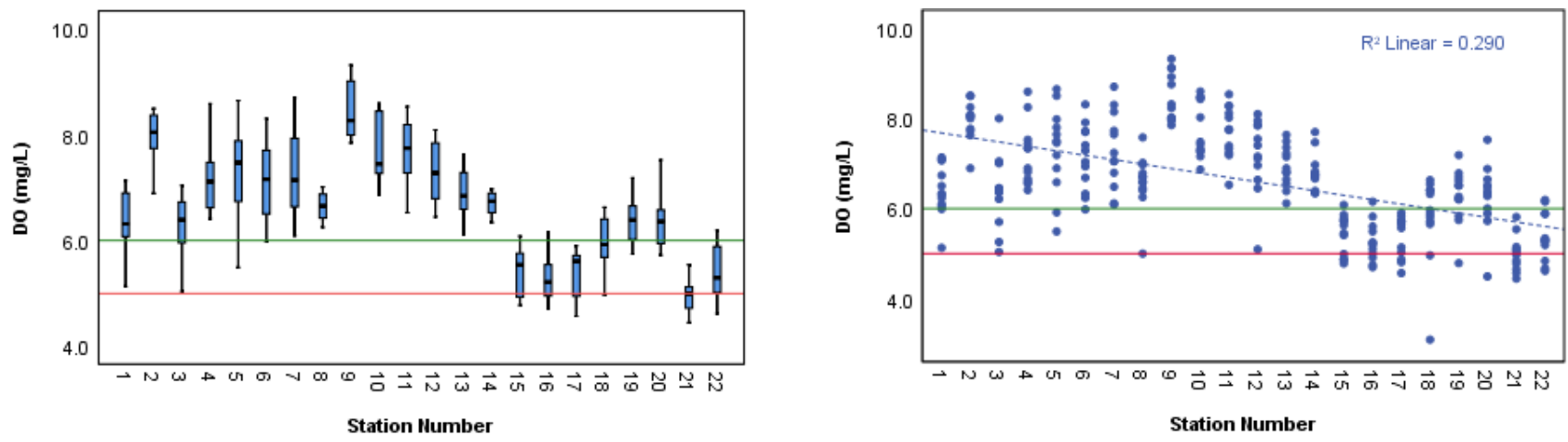

Figure 14. Spatial variation in DO (mg/L) at 22 stations along the Mekong River (1-17) and the Bassac River (18-22), 2018 and illustrated using box-and-whisker plot (left) and dot plot (right)

Note: respectively.

The horizontal lines at 5.0 (red) and 6.0 (green) represent DO target values of the WQGH and the WQGA,

The analysis of the spatial variation of 2018 DO data along the mainstream reveals that, on average, DO concentrations tended to be higher in the upper and middle section of the Mekong River (Figure 14). In 2018, the highest DO value in the Mekong River was observed at Chiang Sean (2) at $11.4 \mathrm{mg} / \mathrm{L}$, Stung Treng (9) at $9.3 \mathrm{mg} / \mathrm{L}$, Vientiane (4) at $8.6 \mathrm{mg} / \mathrm{L}$. The lowest DO value was observed at My Tho (17) Takhamao monitoring station ( $4.5 \mathrm{mg} / \mathrm{L})$. Along the Bassac River, the highest DO concentration was recorded in Koh Thom (20) at $7.5 \mathrm{mg} / \mathrm{L}$ in July 2018, whereas the lowest DO value was recorded at Takhamao monitoring station (18) at 3.1 $\mathrm{mg} / \mathrm{L}$ in March 2018.

At Takhamao Water Quality Monitoring Station (21), more than $58 \%$ of DO values were lower than the MRC WQGH of $6 \mathrm{mg} / \mathrm{L}$; compared to 2017, only $25 \%$ of the DO values at this station were lower than $6 \mathrm{mg} / \mathrm{L}$. 
A temporal analysis of DO in the Mekong River from 1985 to 2018 (Figure 15) reveals that DO concentrations in the mainstream decreased. In 1985, the average DO level was recorded at about $7 \mathrm{mg} / \mathrm{L}$. This value had decreased to about $6.9 \mathrm{mg} / \mathrm{L}$ in 2018 . The reduction appears to be related to the increased levels of COD, $\mathrm{NO}_{32}, \mathrm{NH}_{4}{ }^{+}$, TOTN and TOTP, with significant relationships detected with $\mathrm{NO}_{32}, \mathrm{NH}_{4}$, and $\mathrm{COD}$ (Table 9).
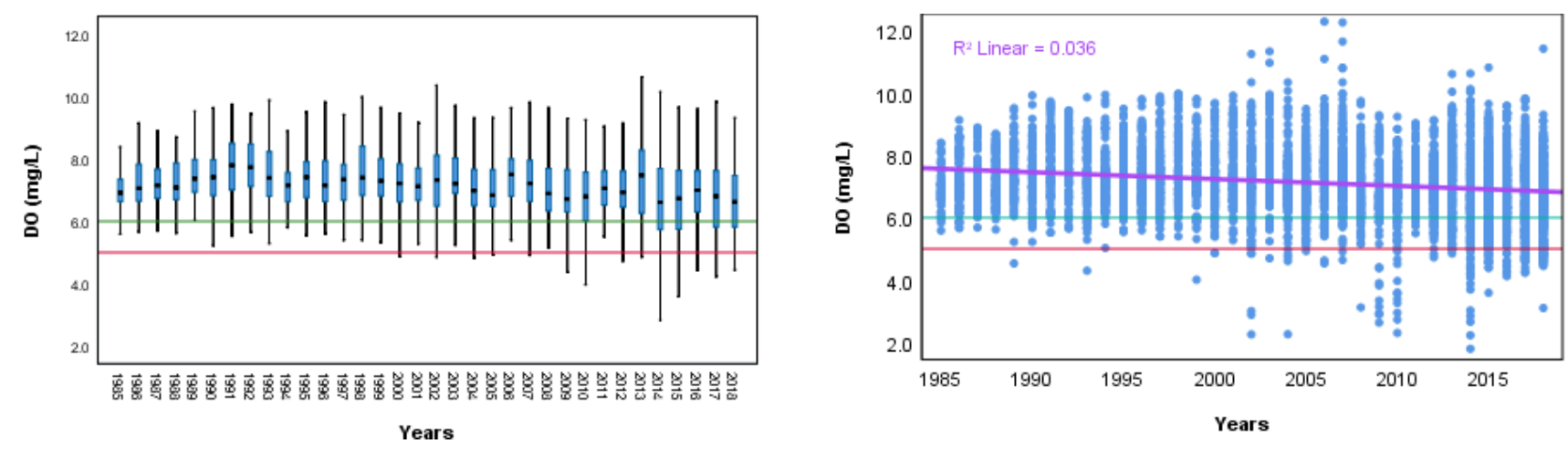

Figure 15. Temporal variation in dissolved oxygen $(\mathrm{mg} / \mathrm{L})$ in the Mekong River as recorded from 1985 to 2018

Note: respectively.

The horizontal lines at 5.0 (red) and 6.0 (green) represent DO target values of the WQGH and the WQGA,

\subsubsection{Chemical oxygen demand}

The amount of oxygen needed to oxidise organic and inorganic material is called chemical oxygen demand (COD), but in most cases, organic components predominate and are more significant (USEPA, 2012a; Lee et al., 2016). In July 2018, the maximum COD concentration in the Mekong River was recorded, at Khong Chiam Water Quality Station, at $6.48 \mathrm{mg} / \mathrm{L}$. The value is slightly higher than the recommended WQGH $(5 \mathrm{mg} / \mathrm{L})$. In general, the COD levels were highest in the upper and Delta part of the river. Levels at stations in these parts of the river are also highly variable compared to those of stations located in the middle section of the river (Figure 16). The lowest COD value was recorded at Stung Treng $(0.13 \mathrm{mg} / \mathrm{L})(9)$ in June 2018. Overall, only about $7 \%$ of the total COD sampling occasions captured levels that were greater than $5 \mathrm{mg} / \mathrm{L}$ (WQGH), contributing to an overall low average COD values in 2018 $(2.47 \mathrm{mg} / \mathrm{L})$. Individually, seven stations recorded COD values exceeding the WQGH of $5 \mathrm{mg} / \mathrm{L}$ at least once in 2018. In comparison, an analysis of 2017 COD data reveals that only five stations recorded COD values higher than the threshold value of the MRC WQGH ( $5 \mathrm{mg} / \mathrm{L})$. No COD threshold value has been set for the WQGA.

Figure 16 shows spatial variations in COD along the Mekong and Bassac Rivers in 2018. As can be seen in the figure, COD concentrations fluctuate as the river runs from upstream to 
downstream, with the lowest and less variable concentrations recorded in the middle section of the river (where, accordingly, DO was found to be highest). The spatial trends of COD appeared to be directly opposite of that of DO, which further confirm the negative relationship of the two parameters as illustrated in Table 9.

In2018, the mean COD concentration in the Bassac River $(2.9 \mathrm{mg} / \mathrm{L})$ was slightly higher than that of the Mekong River $(2.47 \mathrm{mg} / \mathrm{L9}$, which was slightly higher than the value recorded in 2017 ( $2.6 \mathrm{mg} / \mathrm{L})$. This value is lower than the historical mean value of $2.7 \mathrm{mg} / \mathrm{L} \mathrm{from} 1985$ to 2017 (Table 11). The maximum COD concentration of $5.6 \mathrm{mg} / \mathrm{L}$ was recorded at Can Tho, Viet Nam in May 2018.

Figure 17 reveals that COD concentrations in the Mekong River increased slightly from 1985 to 2018. In contrast, the mean COD concentration for the 17 Mekong Stations was about 1.6 $\mathrm{mg} / \mathrm{L}$ in 1985 , while the mean COD concentration for the same stations was about $2.3 \mathrm{mg} / \mathrm{L}$ in 2017, and $2.47 \mathrm{mg} / \mathrm{L}$ in 2018 .
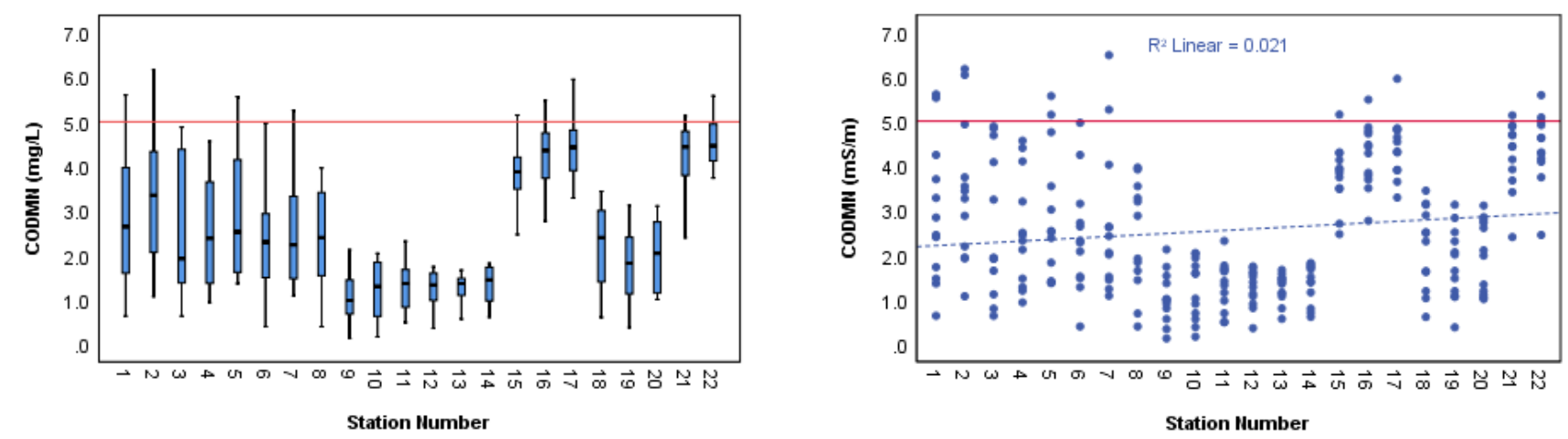

Figure 16. Spatial variation in COD (mg/L) at 22 stations along the Mekong (1-17) and Bassac (18-22) Rivers, 2018 and illustrated using box-and-whisker plot (left) and dot plot (right)

Note:

The horizontal lines at 5.0 represent COD target value of the WQGH.
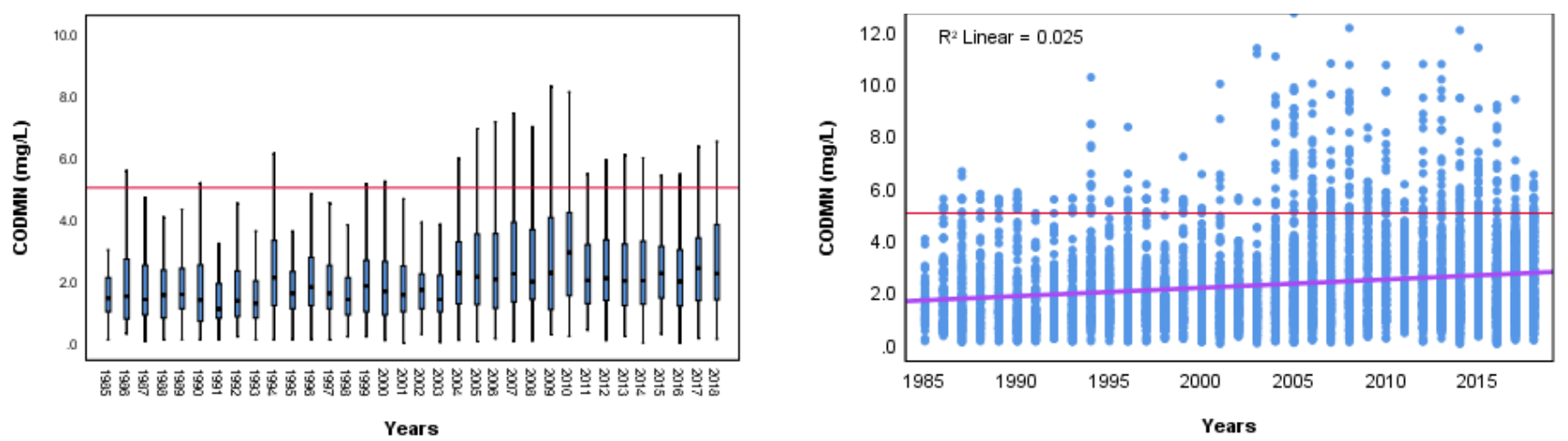

Figure 17. Temporal variation in COD (mg/L) in the Mekong River, from 2000 to 2018 and illustrated using box-and-whisker plot (left) and dot plot (right) 
Note:

The horizontal lines at 5.0 represent COD target value of the WQGH.

\subsection{Transboundary water quality}

The MRC Technical Paper No. 19 (2008) identified five main transboundary areas along the Mekong River for assessing transboundary water quality in the Mekong and Bassac Rivers:

1. China/Lao PDR - A water quality monitoring station was established in Houa Khong in 2004 to monitor the boundary between the Upper and Lower Mekong Basin.

2. Lao PDR/Myanmar - There is no water quality station in this part of the river since it is remote and sparsely populated.

3. Thailand/Lao PDR - There are a number of monitoring stations along this stretch of the Mekong River, including those located in the vicinity of urban areas such as Vientiane, Nakhon Phanom and Savannakhet. However, none of the stations can be referred to as transboundary stations since they receive run-off from both countries and water is normally sampled in the middle of the river.

4. Lao PDR/Cambodia - While not located directly at the border of the two countries, Pakse and Stung Treng monitoring stations have, in the past, been considered as transboundary stations. Data from these stations have been used to assess transboundary effects on water quality.

5. Cambodia/Viet Nam - Both the Mekong and the Bassac Rivers have stations that can be used to capture transboundary effects on water quality. On the Mekong side, Kaorm Samnor station in Cambodia and Tan Chau in Viet Nam are located not too far from the Cambodian/Vietnamese border. Similarly, Koh Thom station in Cambodia and Chau Doc station in Viet Nam, which are located on the Bassac River, can be considered as transboundary stations, due to their proximity to the Cambodian/Vietnamese border. 


\subsubsection{Pakse vs. Stung Treng}

A comparison of water quality at Pakse and Stung Treng Stations was carried out to examine potential transboundary water quality issues in the Mekong River between Lao PDR and Cambodia. For this purpose, six key parameters were selected based on the availability of data to support the assessment. These parameters are nitrate-nitrite, ammonium, TOTN, total phosphorus, DO and COD.

Figure 18 provides a summary of the comparison of 2018 water quality between the two stations. As can been seen in the figure, generally higher concentrations of ammonium were observed at Stung Treng than at Pakse. The average values of ammonium at Pakse and Stung Treng were $M=0.03 \mathrm{mg} / \mathrm{L}(\mathrm{Std} .=0.02)$ and $\mathrm{M}=0.11 \mathrm{mg} / \mathrm{L}(\mathrm{Std} .=0.09)$. These conditions indicate that transboundary water quality issues associated with these parameters might be of potential concern. An independent t-test was carried out to determine whether the difference observed in mean concentrations of nitrate-nitrite, ammonium, and TOTN between the two stations was statistically significant. The results of an independent t-test reveal that the difference in mean concentrations of nitrate-nitrite, ammonium, and TOTN at Pakse was significant with a P-values of less than 0.01 for all three parameters. However, the average values of nitrate-nitrite and TOTN at Pakse were higher than those at Stung Treng. The average values of nitrate-nitrite at Pakse and Stung Treng were $M=0.51 \mathrm{mg} / \mathrm{L}(\mathrm{Std} .=0.19)$ and $\mathrm{M}=$ $0.17 \mathrm{mg} / \mathrm{L}(\mathrm{Std} .=0.08)$, and the average values of TOTN were $0.41 \mathrm{mg} / \mathrm{l}(\mathrm{Std} .=0.15)$ and 0.40 $\mathrm{mg} / \mathrm{l}(\mathrm{Std} .=0.16)$. This indicates that there was likely no transboundary water quality issue of nitrogen between the two stations in 2018.

Similar to conditions observed for nitrate-nitrite, ammonium and TOTN, the P values for DO and COD at Parke and Stung Treng were less than 0.01. The values indicated that there was a significant difference between the means concentration of these parameters at the two stations. DO levels observed at the two stations further reveal that there is no potential issue with transboundary water quality, because the higher concentration was generally observed at Stung Treng, $M=8.5 \mathrm{mg} / \mathrm{L}($ Std. = 0.54), than at Pakse, $6.58 \mathrm{mg} / \mathrm{L}($ Std. $=0.6)$.

Similarly, the average concentration of COD at Stung Treng was recorded at about $1.04 \mathrm{mg} / \mathrm{L}$ $(S t d .=0.57)$ compared to $2.39 \mathrm{mg} / \mathrm{L}(\mathrm{Std} .=1.23)$ recorded at Pakse, which further indicated that there was likely no transboundary water quality issue between the two stations in 2018 regarding COD.

The average concentration of phosphorous at Stung Treng was recorded at about $0.08 \mathrm{mg} / \mathrm{L}$ (Std. $=0.08)$ compared to $0.07 \mathrm{mg} / \mathrm{L}(\mathrm{Std} .=0.02)$ recorded at Pakse. The average values were similar at the two stations, which was further confirmed by the $P$ value of 0.59 . 

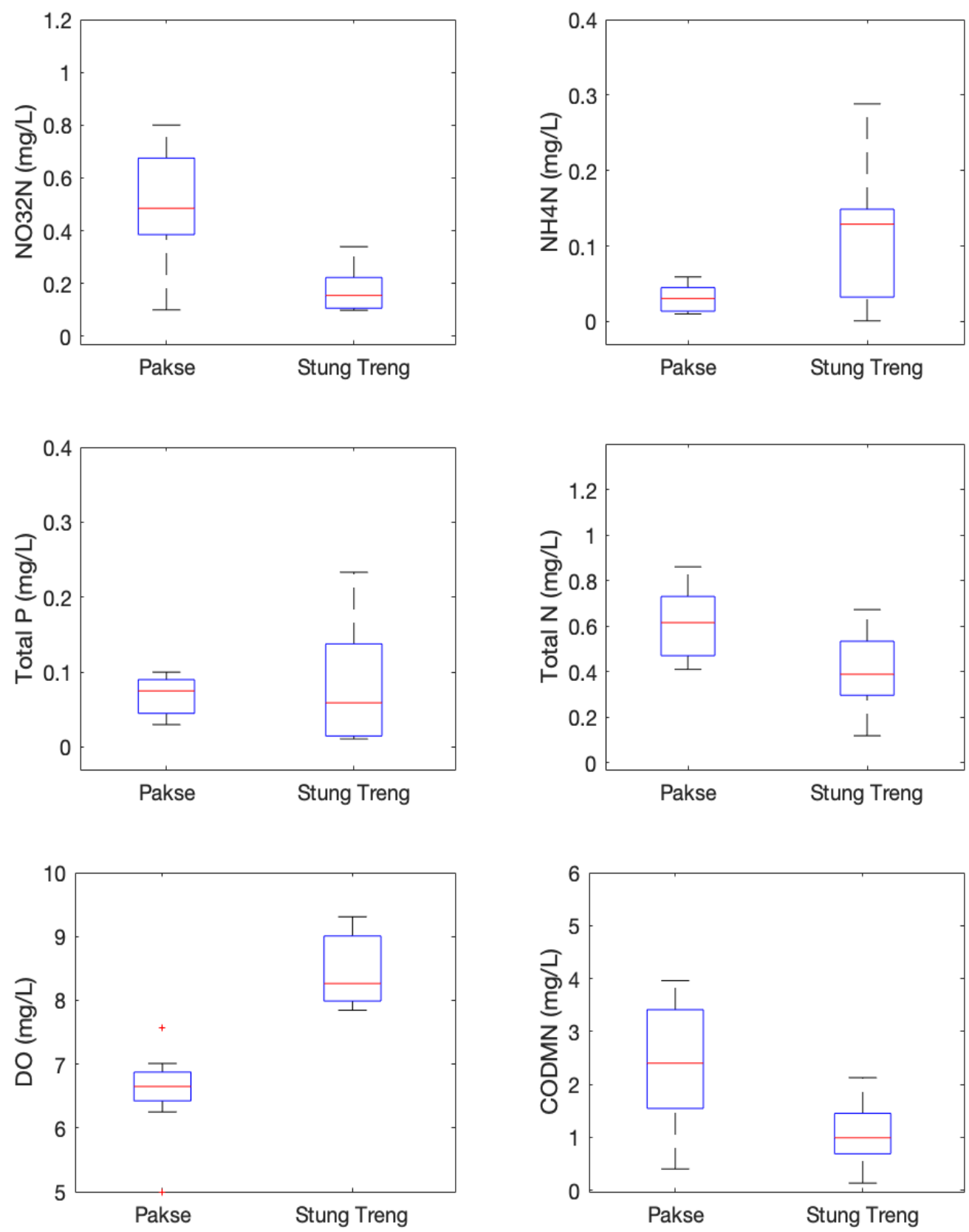

Figure 18. Comparisons of 2018 water quality data at Pakse and Stung Treng

\subsubsection{Kaorm Samnor vs. Tan Chau}

Kaorm Samnor and Tan Chau monitoring stations are located on the Mekong River, with Kaorm Samnor on the Cambodian side and Tan Chau on the Vietnamese side. To assess potential transboundary water quality issues at these two stations, a comparison was made 
on a number of key water quality parameters, including nitrate-nitrite, ammonium, TOTN, total phosphorus, DO and COD. The outcomes of these analyses are illustrated in Figure 19.

In general, water quality in the Mekong River in 2018 was more degraded in Tan Chau than in Kaorm Samnor, with respect to the following parameters: nitrate-nitrite, TOTN, and COD. For instance, in 2018, generally higher levels of nitrate-nitrite, TOTN, and COD were observed at Tan Chau than at Kaorm Samnor. Statistically, Independent t-tests revealed that there were significant differences in levels of $\mathrm{NO}_{32}$, TOTN, and $\mathrm{COD}$ at these two stations with the P values of less than 0.01 . Concentrations of these parameters were higher in the downstream station than in the upstream one, which indicates the possibility of a transboundary water quality issue. However, maximum concentrations did not exceed those of the WQGH and the WQGA in 2018.

With DO appearing to be negatively correlated to $\mathrm{NO}_{32}$, TOTN, and COD (Table 9), the levels of DO at these two stations were directly opposite those of NO32, TOTN, and COD - higher in Kaorm Samnor (Figure 19). The mean concentrations of DO were $M=6.8 \mathrm{mg} / \mathrm{L}(\mathrm{Std}=0.4)$ at Kaorm Samnor and $M=5.4 \mathrm{mg} / \mathrm{L}(\mathrm{Std}=0.4)$ at Tan Chau with the $P$ value of less than 0.01 .

In contrast, an independent t-test showed that there was no significant difference between the mean concentrations of ammonium ( $P$ value of 0.14 ) and total phosphorus ( $P$ value of 0.5 ) concentrations. The mean concentrations of ammonium were $M=0.1 \mathrm{mg} /(S t d=0.1)$ at Kaorm Samnor and $M=0.1 \mathrm{mg} / \mathrm{L}(\mathrm{Std}=0.0)$ at Tan Chau. Similarly, the mean concentrations of Total Phosphorous were $M=0.1 \mathrm{mg} / \mathrm{L}(\mathrm{Std}=0.1$ ) at Kaorm Samnor and $\mathrm{M}=0.1 \mathrm{mg} / \mathrm{L}$ (Std $=0.1$ ) at Tan Chau. 

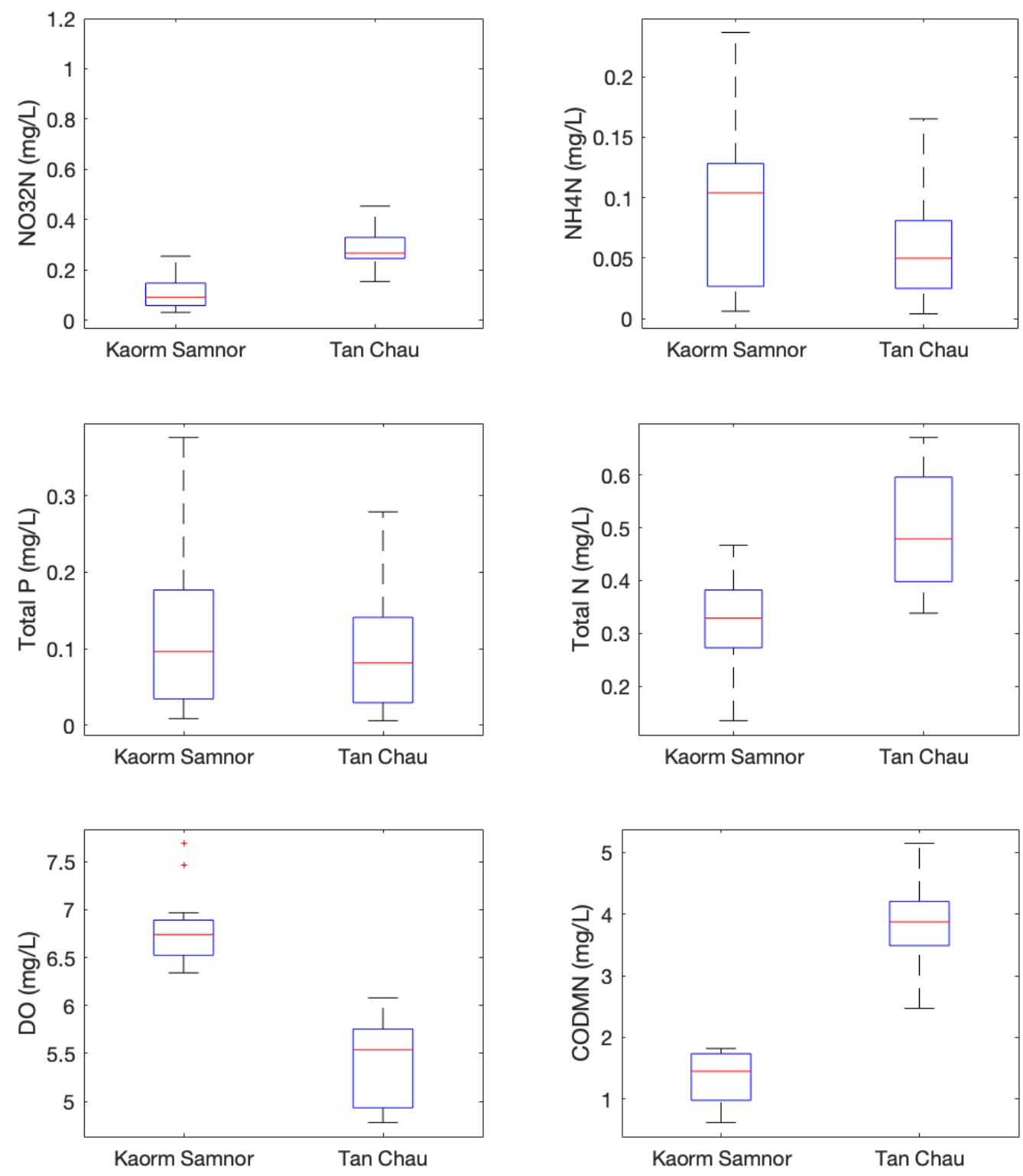

Figure 19. Comparisons of water quality data at Kaorm Samnor and Tan Chau

\subsubsection{Koh Thom vs. Chau Doc}

Similar analysis was carried out for Koh Thom (on the Cambodian side of the river) and Chau Doc (on the Vietnamese side of the river) water quality monitoring stations on the Bassac River to assess potential transboundary water quality issues. Figure 20 illustrates comparisons of the concentrations of nitrate-nitrite, ammonium, TOTN, total phosphorus, DO and COD recorded at Koh Thom and Chau Doc monitoring stations in 2018. 
In terms of pollutant levels, Figure 20 shows that, in 2018, concentrations of $\mathrm{NO}_{32}$, TOTN, and COD were generally higher in the downstream station (Chau Doc) than the upstream station (Koh Thom). This is similar to conditions detected between Kaorm Samnor and Tan Chau (Section 3.2.2) and may reflect pollution discharges between the two stations in relation to these parameters.

The analysis of individual parameters in 2018 for both stations revealed that the observed difference in the mean concentrations of $\mathrm{NO}_{32}$, TOTN, COD, and DO were statistically significant, with a $P$ value of less than 0.01 . Mean nitrate-nitrite concentrations for Koh Thom and Chau Doc were estimated at $0.2 \mathrm{mg} / \mathrm{L}(\mathrm{Std}=0.1)$ and $0.5 \mathrm{mg} / \mathrm{L}(\mathrm{Std}=0.2)$, respectively. However, with the maximum concentrations recorded at less than $1 \mathrm{mg} / \mathrm{L}$ for both stations, $\mathrm{NO}_{32}$ levels at these stations were still well below the recommended WQGH and the WQGA (5 mg/L).

In the case of TOTN, the result of an independent t-test for both stations revealed that the difference in the mean concentrations of TOTN was statistically significant, with a $P$ value of about 0 . Mean TOTN concentrations for Koh Thom and Chau Doc were estimated at $0.4 \mathrm{mg} / \mathrm{L}$ $(\mathrm{Std}=0.11)$ and $0.8 \mathrm{mg} / \mathrm{L}(\mathrm{Std}=0.2)$, respectively.

The observed difference in the mean concentrations of COD, between Koh Thom $(M=2.0$ $\mathrm{mg} / \mathrm{L}, \mathrm{Std}=0.8)$ and Chau Doc $(\mathrm{M}=4.2 \mathrm{mg} / \mathrm{L}, \mathrm{Std}=0.8)$, was statistically significant, with a $P$ value of less than 0.01 . However, the maximum COD concentrations at the two stations were still below the MRC WQGH $(5 \mathrm{mg} / \mathrm{L})$, indicating that there is no transboundary issue.

DO concentrations at Chau Doc were recorded to be generally lower than those recorded at Koh Thom. A comparison of mean DO concentrations between the two stations revealed that the difference was statistically significant, with a $P$ value of less than 0.01 . Mean DO concentrations for Koh Thom and Chau Doc were estimated at $6.3 \mathrm{mg} / \mathrm{L}(\mathrm{Std}=0.7$ ) and $5 \mathrm{mg} / \mathrm{L}$ (Std $=0.4)$, respectively. With $100 \%$ of DO values monitored in Chau Doc being lower than 6 $\mathrm{mg} / \mathrm{L}(\mathrm{WQGH})$, there is a potential concern with regard to the human use of river at the station. It should be noted, however, that although all values exceeded the WQGH $(6 \mathrm{mg} / \mathrm{L})$, none violated the WQGA, indicating that the water quality at the station was still suitable for aquatic life, but should be closely monitored to ensure the detection of potential future violation of the WQGA. 

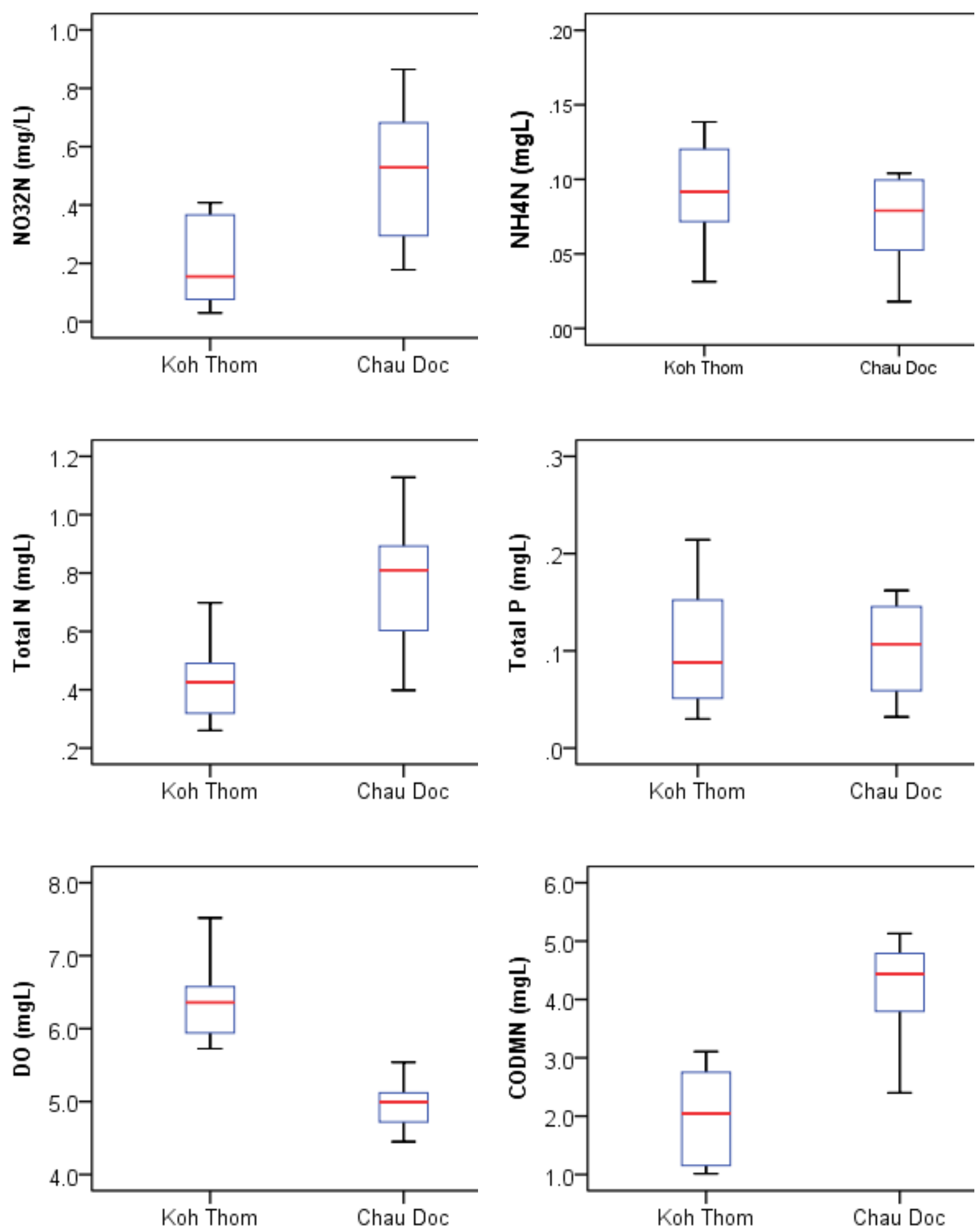

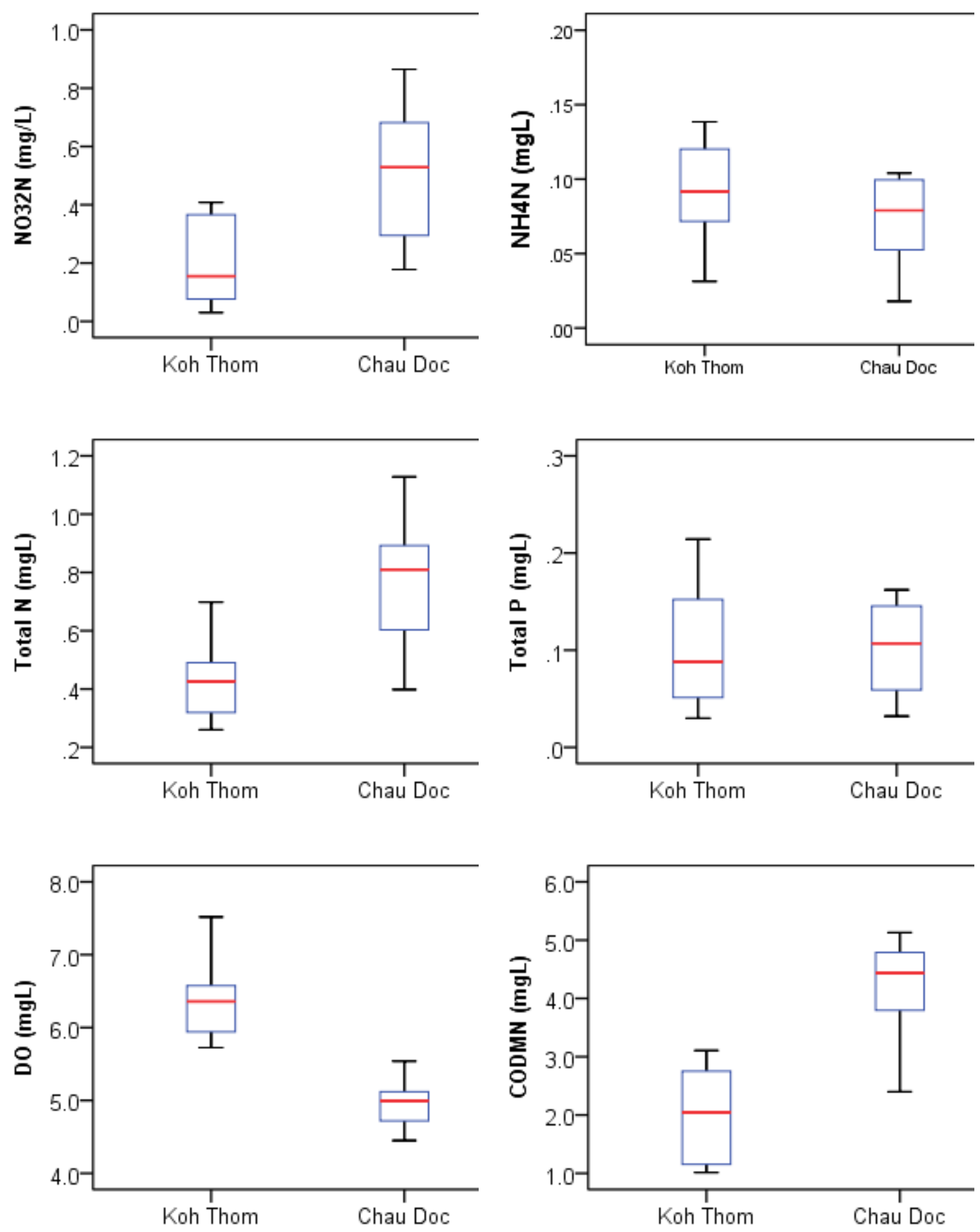

Figure 20. Comparisons of water quality data at Koh Thom and Chau Doc 


\subsection{The water quality indices}

\subsubsection{The Water Quality Index for the Protection of Aquatic Life}

In 2018, water quality of the Mekong and Bassac Rivers was classified in a range from 'moderate' to 'excellent' for the protection of aquatic life (Table 12). In 2018, four stations were classified as 'excellent' for the protection of aquatic life, including Luang Prabang, Vientiane, Khong Chiam and Stung Treng. In contrast, water quality in one station was recorded as only 'moderate' for the protection of aquatic life (Chau Doc). The remaining stations were classified as 'good' for the protection of aquatic life.

Compared to 2017, the water quality of Mekong and Bassac Rivers was classified as less suitable for aquatic life, with only three stations (Luang Prabang, Vientiane, Khong Chiam, and Stung Treng) rated as 'excellent'. In comparison, nine stations were recorded as 'excellent' in 2017. Overall, water quality at eight stations was worse in 2018 than in 2017: according to the WQGA, the classification of water quality in seven stations decreased from 'excellent' to 'good' (Savannakhet, Pakse, Kampong Cham, Chrouy Changvar, Neak Loung, Kaorm Samnor and Tan Chau) and one station from 'good' to 'moderate' (Chau Doc). This was due to the elevated levels in total $\mathrm{COD}, \mathrm{NO}_{32}$, and $\mathrm{NH}_{4}$, and the reduction in $\mathrm{DO}$ concentrations.

In contrast, 2018 saw water quality improvement at two stations where the rating according to the WQGA improved from 'good' to 'excellent'. These two stations were Luang Prabang and Khong Chiam. The improvement was due to the improved levels of DO and reduced instream concentration levels of $\mathrm{NO}_{32}$ compared to levels recorded in 2017.

Table 12. Rating of water quality of the Mekong River (from 1 to 17) and the Bassac

River (from 18 to 22) according to the WQGA, 2008-2018

\begin{tabular}{|c|c|c|c|c|c|c|c|c|c|c|c|c|c|}
\hline \multirow[b]{2}{*}{ No. } & \multirow[b]{2}{*}{ Station Names } & \multirow[b]{2}{*}{ Countries } & \multicolumn{11}{|c|}{ Class } \\
\hline & & & $\begin{array}{c}200 \\
8\end{array}$ & $\begin{array}{c}200 \\
9\end{array}$ & $\begin{array}{c}201 \\
0\end{array}$ & $\begin{array}{c}201 \\
1\end{array}$ & $\begin{array}{c}201 \\
2\end{array}$ & $\begin{array}{c}201 \\
3\end{array}$ & $\begin{array}{c}201 \\
4\end{array}$ & $\begin{array}{c}201 \\
5\end{array}$ & $\begin{array}{c}201 \\
6\end{array}$ & $\begin{array}{c}201 \\
7 \\
\end{array}$ & $\begin{array}{c}201 \\
8 \\
\end{array}$ \\
\hline 1 & Houa Khong & Lao PDR & $A^{*}$ & A & A & A & B & B & B & B & B & B & B \\
\hline 2 & Chiang Saen & Thailand & $\mathbf{A}$ & B & B & A & B & B & A & B & B & B & B \\
\hline 3 & Luang Prabang & Lao PDR & $\mathbf{A}$ & A & B & A & A & B & B & B & A & B & $\mathbf{A}$ \\
\hline 4 & Vientiane & Lao PDR & A & A & A & A & A & B & B & A & A & A & A \\
\hline 5 & Nakhon Phanom & Thailand & B & A & B & A & B & B & A & A & B & B & B \\
\hline 6 & Savannakhet & Lao PDR & A & A & A & A & A & B & B & B & A & A & B \\
\hline 7 & Khong Chiam & Thailand & B & A & A & A & A & B & A & A & A & B & A \\
\hline 8 & Pakse & Lao PDR & A & A & A & A & A & B & B & B & A & A & B \\
\hline 9 & Stung Trieng & Cambodia & B & B & B & B & B & B & B & B & B & A & A \\
\hline 10 & Kratie & Cambodia & B & B & B & B & B & B & B & B & A & B & B \\
\hline 11 & Kampong Cham & Cambodia & B & B & B & B & B & B & A & B & A & A & B \\
\hline 12 & Chrouy Changvar & Cambodia & B & B & B & B & B & B & B & B & A & A & B \\
\hline 13 & Neak Loung & Cambodia & B & B & B & B & B & B & B & B & A & A & B \\
\hline 14 & Kaorm Samnor & Cambodia & B & B & B & B & B & B & B & B & A & A & B \\
\hline 15 & Tan Chau & Viet Nam & B & B & B & B & B & B & B & B & B & A & B \\
\hline 16 & My Thuan & Viet Nam & B & B & B & B & B & B & B & B & B & B & B \\
\hline
\end{tabular}




\begin{tabular}{|l|l|l|l|l|l|l|l|l|l|l|l|l|l|} 
17 & My Tho & Viet Nam & C & C & C & C & B & C & C & C & D & C & B \\
\hline 18 & Takhmao & Cambodia & B & B & B & B & B & B & B & B & B & B & B \\
\hline 19 & Koh Khel & Cambodia & B & B & B & B & B & B & B & B & B & B & B \\
\hline 20 & Koh Thom & Cambodia & B & B & B & B & B & B & A & B & B & B & B \\
\hline 21 & Chau Doc & Viet Nam & B & B & B & B & B & B & B & B & B & B & C \\
\hline 22 & Can Tho & Viet Nam & B & C & C & C & C & C & B & B & B & B & B \\
\hline
\end{tabular}

Note:

*A: High; B: Good; C: Moderate; D: Poor; E: Very Poor.

\subsubsection{Water Quality Index for the Protection of Human Health}

Analysis of the 2018 water quality data, using the Water Quality Index for Human Health, reveals that water quality of the Mekong and Bassac Rivers for the protection of human health is still of good quality, with all stations rated as either 'good' or 'excellent' (Table 13).

in 2018, 11 of the 22 stations located in the Mekong and Bassac Rivers were classified as 'excellent' for the protection of human health while the other 11 were classified as 'good'. Among the 11 stations classified as 'excellent', six stations were located in Cambodia. With the three Bassac River's monitoring stations (Koh Khel and Koh Thom) also classified as 'excellent', all stations monitored by the Cambodian WQMN laboratory in 2018 were classified as 'excellent' in 2018. Since 2009, these stations have been consistently rated as 'excellent' for human health acceptability.

Historically, water quality of the Mekong and Bassac Rivers has been acceptable for human health with a classification of mostly 'good' or 'excellent'. The only exceptions were recorded in 2009 (Tan Chau, My Tho and Chau Doc), 2010 (My Thuan, My Tho, Chau Doc, and Can Tho) and 2014 (Houa Khong, Savannakhet, and Takhmao) where a few stations were classified as "moderate". Despite the overall 'good' to 'excellent' quality, water quality of the Mekong and Bassac Rivers slightly degraded in 2018 compared to in 2017, with five stations recorded lower rating scores compared to the previous years (Table 13). These stations were Houa Khong, Luang Prabang, Tan Chau, Takhmao and Can Tho.

Table 13. Rating of water quality of the Mekong River (from 1 to 17) and the Bassac River (from 18 to 22) for the protection of human health, 2008-2018

\begin{tabular}{|c|c|c|c|c|c|c|c|c|c|c|c|c|c|}
\hline \multirow{2}{*}{ No. } & \multirow{2}{*}{ Station Names } & \multirow{2}{*}{ Countries } & \multicolumn{11}{|c|}{ Class } \\
\hline & & & 2008 & 2009 & 2010 & 2011 & 2012 & 2013 & 2014 & 2015 & 2016 & 2017 & 2018 \\
\hline 1 & Houa Khong & Lao PDR & $A^{*}$ & A & B & A & B & B & C & A & A & A & B \\
\hline 2 & Chiang Saen & Thailand & B & B & B & $A$ & B & B & B & B & B & B & B \\
\hline 3 & Luang Prabang & Lao PDR & A & A & B & A & B & A & B & B & B & A & B \\
\hline 4 & Vientiane & Lao PDR & A & A & B & A & B & B & B & B & B & A & A \\
\hline 5 & $\begin{array}{l}\text { Nakhon } \\
\text { Phanom }\end{array}$ & Thailand & B & B & B & B & B & B & B & B & B & B & B \\
\hline 6 & Savannakhet & Lao PDR & A & A & A & A & B & B & C & B & B & A & A \\
\hline 7 & Khong Chiam & Thailand & B & B & B & A & B & B & B & B & B & B & B \\
\hline 8 & Pakse & Lao PDR & B & A & A & A & A & B & A & B & B & A & A \\
\hline
\end{tabular}




\begin{tabular}{|c|c|c|c|c|c|c|c|c|c|c|c|c|c|}
\hline 9 & Stung Trieng & Cambodia & B & A & A & A & A & A & A & A & A & A & A \\
\hline 10 & Kratie & Cambodia & B & A & A & A & A & A & A & A & A & A & A \\
\hline 11 & $\begin{array}{l}\text { Kampong } \\
\text { Cham }\end{array}$ & Cambodia & B & A & A & A & A & A & A & B & A & A & A \\
\hline 12 & $\begin{array}{l}\text { Chrouy } \\
\text { Changvar }\end{array}$ & Cambodia & B & A & A & A & A & A & A & A & A & A & A \\
\hline 13 & Neak Loung & Cambodia & B & A & $\mathbf{A}$ & A & A & A & A & B & A & $\mathbf{A}$ & A \\
\hline 14 & Kaorm Samnor & Cambodia & B & A & A & A & B & A & A & B & A & A & A \\
\hline 15 & Tan Chau & Viet Nam & B & C & B & B & A & A & A & A & A & A & B \\
\hline 16 & My Thuan & Viet Nam & B & B & C & A & A & B & A & A & A & B & B \\
\hline 17 & My Tho & Viet Nam & B & C & C & B & B & B & B & A & B & B & B \\
\hline 18 & Takhmao & Cambodia & B & A & A & A & A & B & C & A & B & A & B \\
\hline 19 & Koh Khel & Cambodia & A & A & B & A & B & B & $A$ & B & $A$ & A & A \\
\hline 20 & Koh Thom & Cambodia & B & A & A & A & B & B & A & A & A & A & A \\
\hline 21 & Chau Doc & Viet Nam & B & C & C & B & B & A & A & A & A & B & B \\
\hline 22 & Can Tho & Viet Nam & B & B & C & B & A & $A$ & A & $A$ & A & A & B \\
\hline
\end{tabular}

Note:

*A: Excellent; B: Good; C: Moderate; D: Poor; E: Very Poor

\subsubsection{Water quality indices for agricultural use}

The level of degradation of water quality for agricultural use was assessed using the MRC water quality indices for Agricultural Use. While two indices were adopted by the MRC to assess the level of degradation of water quality for general irrigation and paddy rice irrigation, all indices for agricultural use can be assessed against threshold values for EC (Table 8).

An analysis of $C$ reveals that all EC values fell within the guideline value of $70 \mathrm{mS} / \mathrm{m}$ for the Water Quality Index for General Irrigation Use. With no recorded value greater than $70 \mathrm{mS} / \mathrm{m}$, it can be concluded that there was no restriction for all types of agricultural use of Mekong and Bassac River water in the upper part of the river. However, when using water for agriculture in the Delta of Viet Nam, it is necessary to thoroughly examine the water quality. The level of impairment of the Mekong and Bassac Rivers' water quality for agricultural use is summarised in Table 14. The WQl $\mathrm{W}_{\mathrm{ag}}$ has been relatively stable in the last 10 years, with water quality from all the stations classified as ' $A$ ', which implies no restrictions for general irrigation and paddy rice.

Table 14. Rating of water quality of the Mekong River (from 1 to 17) and the Bassac River (from 18 to 22) for agricultural use, 2008-2018

\begin{tabular}{|c|l|l|c|c|c|c|c|c|c|c|c|c|c|}
\hline \multirow{2}{*}{ No. } & \multirow{2}{*}{ Station Names } & Countries & \multicolumn{10}{|c|}{ Class } \\
\cline { 4 - 15 } & & & 2008 & $\mathbf{2 0 0 9}$ & $\mathbf{2 0 1 0}$ & $\mathbf{2 0 1 1}$ & $\mathbf{2 0 1 2}$ & $\mathbf{2 0 1 3}$ & $\mathbf{2 0 1 4}$ & $\mathbf{2 0 1 5}$ & $\mathbf{2 0 1 6}$ & $\mathbf{2 0 1 7}$ & $\mathbf{2 0 1 8}$ \\
\hline 1 & Houa Khong & Lao PDR & A* & A & A & A & A & A & A & A & A & A & A \\
\hline 2 & Chiang Saen & Thailand & A & A & A & A & A & A & A & A & A & A & A \\
\hline 3 & Luang Prabang & Lao PDR & A & A & A & A & A & A & A & A & A & A & A \\
\hline 4 & Vientiane & Lao PDR & A & A & A & A & A & A & A & A & A & A & A \\
\hline 5 & $\begin{array}{l}\text { Nakhon } \\
\text { Phanom }\end{array}$ & Thailand & A & A & A & A & A & A & A & A & A & A & A \\
\hline
\end{tabular}




\begin{tabular}{|c|c|c|c|c|c|c|c|c|c|c|c|c|c|}
\hline No. & Station Names & Countries & \multicolumn{11}{|c|}{ Class } \\
\hline 6 & Savannakhet & Lao PDR & A & A & A & A & A & A & A & A & A & A & A \\
\hline 7 & Khong Chiam & Thailand & A & A & A & A & A & A & A & A & A & A & A \\
\hline 8 & Pakse & Lao PDR & A & A & A & A & A & A & A & A & A & A & A \\
\hline 10 & Kratie & Cambodia & A & A & A & A & A & A & A & A & A & A & A \\
\hline 11 & Kampong Cham & Cambodia & A & A & A & A & A & A & A & A & A & A & A \\
\hline 12 & $\begin{array}{l}\text { Chrouy } \\
\text { Changvar }\end{array}$ & Cambodia & A & A & A & A & A & A & A & A & A & A & A \\
\hline 16 & My Thuan & Viet Nam & A & A & A & A & A & A & A & A & A & A & A \\
\hline 17 & My Tho & Viet Nam & A & A & A & A & A & A & A & A & B & A & A \\
\hline 18 & Takhmao & Cambodia & A & A & A & A & A & A & A & A & A & A & A \\
\hline 19 & Koh Khel & Cambodia & A & A & A & A & A & A & A & A & A & A & A \\
\hline 20 & Koh Thom & Cambodia & A & A & A & A & A & A & A & A & A & A & A \\
\hline 21 & Chau Doc & Viet Nam & A & A & A & A & A & A & A & A & A & A & A \\
\hline 22 & Can Tho & Viet Nam & A & A & A & A & A & A & A & A & A & A & A \\
\hline
\end{tabular}

Note:

${ }^{*} \mathrm{~A}$ : No restriction; B: Some restriction; C: Severe restriction 


\section{Conclusions and recommendations}

\subsection{Conclusions}

This report provides an overall assessment of water quality of the Mekong and Bassac River in 2018, using 19 water quality parameters recommended in the MRC TGPWQ as proxies for water quality. The analyses of water quality data collected from 17 Mekong River and 5 Bassac River monitoring stations revealed that water at these stations was of good quality in 2018, with only a small number of COD and DO measurements that did not comply with the WQGH and the WQGA (Tables 10 and 11).

Most the exceedances were recorded in the Delta. Of a slight concern is the DO levels at Chau Doc, which were not in compliance with the WQGH for all sampling occasions, causing the rating of Water Quality Index for the Protection of Aquatic Life to be downgraded from 'good' in 2017 to 'moderate' in 2018. Prior to 2018, water quality at Chau Doc was consistently rated 'good' for the protection of aquatic life. The Pearson's correlation analysis revealed that the reduction in $\mathrm{DO}$ levels was related to the elevated levels in $\mathrm{COD}$ and $\mathrm{NO}_{32}$. Increased levels of $\mathrm{COD}$ and $\mathrm{NO}_{32}$ have been known to increase the amount of instream oxidizable organic materials that consume oxygen during breakdown processes (Woodard and Curran, 2006). Outside of the 'moderate' classification recorded at Chau Doc, water quality of the Mekong and Bassac Rivers for the protection of aquatic life was either 'good' or 'excellent' with four stations classified as 'excellent'. However, when compared to 2017, a combination of reducing DO levels and increasing $\mathrm{COD}, \mathrm{NO}_{32}$, and $\mathrm{NH}_{4}$ levels appeared to have affected the classification of the Water Quality Index for the Protection of Aquatic Life at seven stations, which lowered from 'excellent' in 2017 to 'good' in 2018.

Despite the increased levels of impairment to the aquatic life, water quality of the Mekong and Bassac River continued to be either 'good' or 'excellent' for human health with $50 \%$ rated as 'good' and the remaining rated as 'excellent'. It should be noted that the water quality at all Mekong and Bassac River stations within Cambodia was rated 'excellent' in 2018 for the protection of human health.

With the exception of the non-compliance recorded in DO and COD levels, EC levels were recorded to be well below the lowest allowable limit of the MRC Water Quality Guidelines for the Protection of Human Health and Aquatic Life (70-150 ms/m). However, it should be noted that the Mekong River is generally characterized as a low saline river with the average EC rarely exceeding $40 \mathrm{mS} / \mathrm{m}$ and historical average of 20.7 when sampling during low tide (Section 3.1.2). With no recorded noncompliance with the guideline values for Water Quality Indices for General Irrigation and Paddy Rice Irrigation, it can be concluded that there were no restriction for any type of agricultural use of the Mekong and Bassac Rivers water. It should be noted, however, that water quality monitoring in the Mekong Delta was undertaken during low tide, and therefore, suitability of water for agricultural use may differ during the high tide. 
Compared to the 2017 data, water quality of the Mekong and Bassac River did not change significantly in 2018. However, historical comparisons (1985 to 2018) suggest that water quality changed significantly for many parameters including TSS, which showed a reduction of yearly mean concentration from $388 \mathrm{mg} / \mathrm{L}$ in 1985, to $84.9 \mathrm{mg} / \mathrm{L}$ in 2018, i.e. about a $78 \%$ reduction. Concentrations of $\mathrm{NO}_{32}, \mathrm{NH}_{4}, \mathrm{COD}$ and $\mathrm{DO}$ also changed during the same period, with DO levels reduced from $7 \mathrm{mg} / \mathrm{L}$ in 1985, to $6.9 \mathrm{mg} / \mathrm{L}$ in 2018, while COD level increased from 1.6 to $2.47 \mathrm{mg} / \mathrm{L}$.

In terms of transboundary river pollution, while analyses of water quality data at Pakse/Stung Treng, Kaorm Samnor/Tan Chau, and Koh Thom/Chau Doc reveal significant differences of levels of $\mathrm{NO}_{32}$, TOTN, and COD at these stations, with $\mathrm{P}$ values of less than 0.01 , the levels were still well below the WQGH and the WQGA. However, the combined levels of these pollutants appear to have affected DO levels, in particular at Chau Doc, and should continue to be closely monitored to ensure that any further change that may have potential effects on human health and aquatic life are detected in a timely manner and remedial action is taken.

\subsection{Recommendations}

The MRC MCs' efforts to maintain acceptable/good water quality of the Mekong and Bassac Rivers requires that compliance with the Procedure for Water Quality and its associated Technical Guidelines (TGWQ) are closely monitored. The TGWQ provides a number of additional water quality indicators for monitoring in the near future. These indicators have been added taking into account emerging threats to water quality, including population growth, intensive agriculture and aquaculture, navigation, hydropower and industrialisation, which can often lead to increased inputs of chemicals and debris that can ultimately affect the aquatic ecosystems and human health.

While specific monitoring programmes have been carried out to complement activities of the WQMN, including the Joint Environmental Monitoring and the Multi-Media Monitoring and Assessment of the Mekong Riverine, considering the current status of water quality as highlighted in the report and a potential increase in development and population growth, the following are recommended for the sustainable implementation of the routine water quality monitoring under the MRC WQMN:

- Closely monitor the DO levels in the mainstream stations including those highlighted in this report as being of concern in order to ensure that any further change that may have potential effects on human health and aquatic life are detected in a timely manner and remedial action is taken.

- Explore the feasibility and potential short- and long-term monitoring benefits of riverine micro and macro plastic monitoring taking into consideration the status of these pollutants and their current and future risks to the aquatic ecosystems and human health.

- Improve and update the water quality monitoring knowledge and skills for national laboratories by providing the training programmes. 
- Find the solutions to improve the sampling processes, especially in remote areas (e.g. close to the Lao PDR-Myanmar border and possibly the Lao PDR-China border).

- Explore the feasibility for monitoring additional water quality parameters listed in Chapters 1 and 2 of the TGWQ including heavy metals and persistent and nonpersistent organic substances.

- Further apply and expand JEM programme to install automatic monitoring stations at some selected stations especially at 200-500 m downstream of each Mekong mainstream dams to have timely, high frequency delivery of information on water quality.

- Continue to conduct proficiency tests at laboratories with support from the MRCS.

- Assist national designated laboratories in achieving ISO/IEC 17025 certificates, which will certify that they operate competently and generate valid results. This would promote confidence in the monitoring results nationally, regionally and globally. 


\section{References}

Al, L., SHI, Z. H., YIN, W. \& HUANG, X. 2015. Spatial and seasonal patterns in stream water contamination across mountainous watersheds: Linkage with landscape characteristics. Journal of Hydrology, 523, 398-408.

BENESTY, J., CHEN, J., HUANG, Y. \& COHEN, I. 2009. Pearson correlation coefficient. Noise reduction in speech processing. Springer.

CCME 2001. CCME Water Quality Index 1.0. Tehnical Report. Hull, Quebec: Canadian Council of Ministers of the Environment. .

CHANG, H. 2008. Spatial analysis of water quality trends in the Han River basin, South Korea. Water Research, 42, 3285-3304.

CHEN, H. \& CHANG, H. 2014. Response of discharge, TSS, and E. coli to rainfall events in urban, suburban, and rural watersheds. Environmental Science: Processes \& Impacts, 16, 2313-2324.

FISHER, M. J. \& MARSHALL, A. P. 2009. Understanding descriptive statistics. Australian Critical Care, 22, 93-97.

FU, L. \& WANG, Y.-G. 2012. Statistical Tools for Analyzing Water Quality Data [Online]. InTech. Available: $\quad$ https://www.intechopen.com/books/water-quality-monitoring-andassessment/statistical-tools-for-analyzing-water-quality-data [Accessed 11 November 2017].

GU, Q., HU, H., MA, L., SHENG, L., YANG, S., ZHANG, X., ZHANG, M., ZHENG, K. \& CHEN, L. 2019. Characterizing the spatial variations of the relationship between land use and surface water quality using self-organizing map approach. Ecological Indicators, 102, 633-643.

HE, D., LU, Y., LI, Z. \& LI, S. 2009. Chapter 14 - Watercourse Environmental Change in Upper Mekong A2 - by, Edited. In: CAMPBELL, I. C. (ed.) The Mekong. San Diego: Academic Press.

HERNGREN, L., GOONETILLEKE, A. \& AYOKO, G. A. 2005. Understanding heavy metal and suspended solids relationships in urban stormwater using simulated rainfall. Journal of Environmental Management, 76, 149-158.

JOHNSON, H. O., GUPTA, S. C., VECCHIA, A. V. \& ZVOMUYA, F. 2009. Assessment of Water Quality Trends in the Minnesota River using Non-Parametric and Parametric Methods. Journal of Environmental Quality, 38, 1018-30.

LEE, J. 2020. Statistics, Descriptive. In: KOBAYASHI, A. (ed.) International Encyclopedia of Human Geography (Second Edition). Oxford: Elsevier.

LEE, J., LEE, S., YU, S. \& RHEW, D. 2016. Relationships between water quality parameters in rivers and lakes: BOD5, COD, NBOPs, and TOC. Environmental Monitoring and Assessment, 188, 252.

LY, K., METTERNICHT, G. \& MARSHALL, L. 2020. Linking Changes in Land Cover and Land Use of the Lower Mekong Basin to Instream Nitrate and Total Suspended Solids Variations. Sustainability, 12, 2992.

MEKONG RIVER COMMISSION 2018. State of the Basin Report 2018. Vientiane, Lao PDR: The Mekong River Commission Secretariat.

RICE, E., BAIRD, R., EATON, A. \& LENORE, S. 2012. Standard methods: For the examination water and wastewater, 22nd edn. American Public Health Association, American Water Works Association, Water Environmental Federation. ISSN. 
USEPA 2012a. 5.2 dissolved oxygen and biochemical oxygen demand. Water: monitoring and assessment. United States Environmental Protection Agency.

USEPA 2012b. Water: Monitoring and Assessment. In: AGENCY, T. U. S. E. P. (ed.). USA.

USEPA 2014. Conductivity. In: AGENCY, U. S. E. P. (ed.). Washington DC. USA.

WETZEL, R. G. 2001. 10 - SALINITY OF INLAND WATERS. In: WETZEL, R. G. (ed.) Limnology (Third Edition). San Diego: Academic Press.

WOODARD \& CURRAN, I. 2006. 5 - Waste Characterization. In: WOODARD \& CURRAN, I. (eds.) Industrial Waste Treatment Handbook (Second Edition). Burlington: ButterworthHeinemann. 


\section{Annexes: Trends of Key Water Quality Parameters in the Tributaries of the Mekong River}

Annexe 1.1 Chiang Rai (Thailand)

Table A.1. Trends of key water quality parameters at Chiang Rai Water Quality Station

\begin{tabular}{|c|c|c|c|}
\hline Parameters & Unit & Kendall tau values & -values \\
\hline $\mathrm{pH}$ & - & -0.18 & $2.0234 \mathrm{e}-07$ \\
\hline $\mathrm{TSS}$ & $\mathrm{mg} / \mathrm{L}$ & -0.082 & 0.017911 \\
\hline $\mathrm{EC}$ & $\mathrm{mS} / \mathrm{m}$ & 0.141 & $5.1017 \mathrm{e}-05$ \\
\hline $\mathrm{NO}_{3-2}-\mathrm{N}$ & $\mathrm{mg} / \mathrm{L}$ & 0.00775 & 0.8261 \\
\hline $\mathrm{NH}_{4}-\mathrm{N}$ & $\mathrm{mg} / \mathrm{L}$ & 0.0763 & 0.034179 \\
\hline $\mathrm{TOTP}$ & $\mathrm{mg} / \mathrm{L}$ & 0.371 & $2.22 \mathrm{e}-16$ \\
\hline $\mathrm{DO}$ & $\mathrm{mg} / \mathrm{L}$ & 0.00835 & 0.81457 \\
\hline CODMN & $\mathrm{mg} / \mathrm{L}$ & 0.327 & $2.22 \mathrm{e}-16$ \\
\hline
\end{tabular}

Note:

p-value $<0.05$ indicates significant change, negative (-) Kendall tau value indicates decreasing trend, and positive $(+)$ Kendall tau value indicates increasing trend.
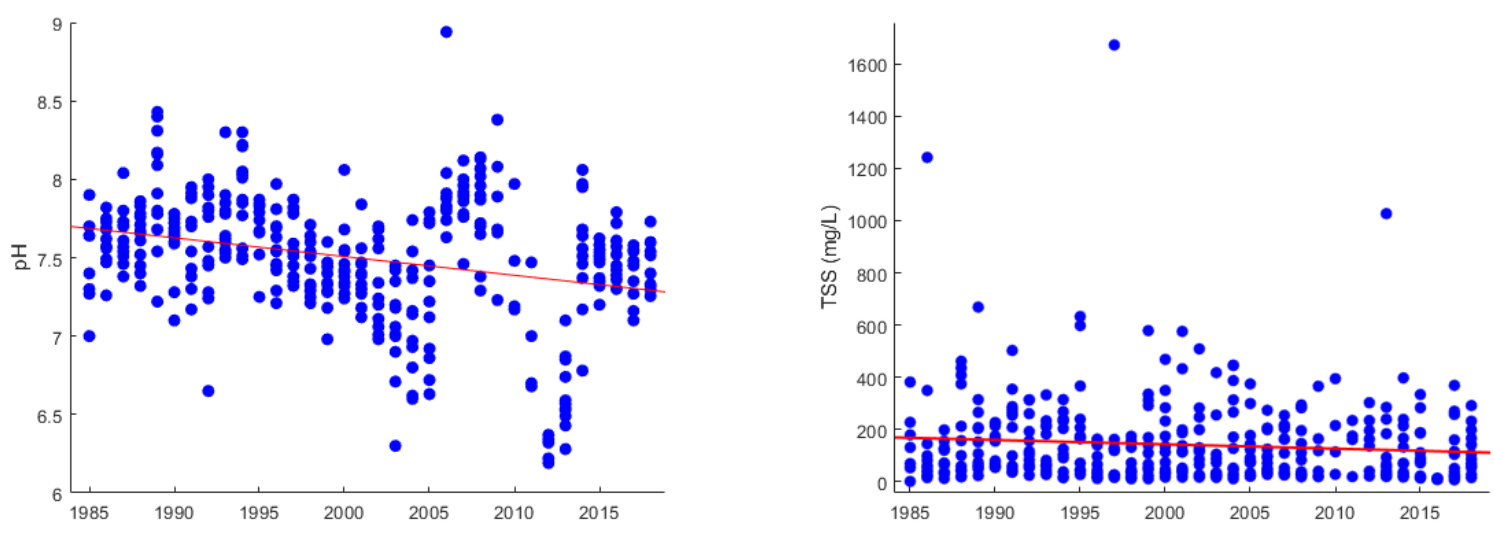

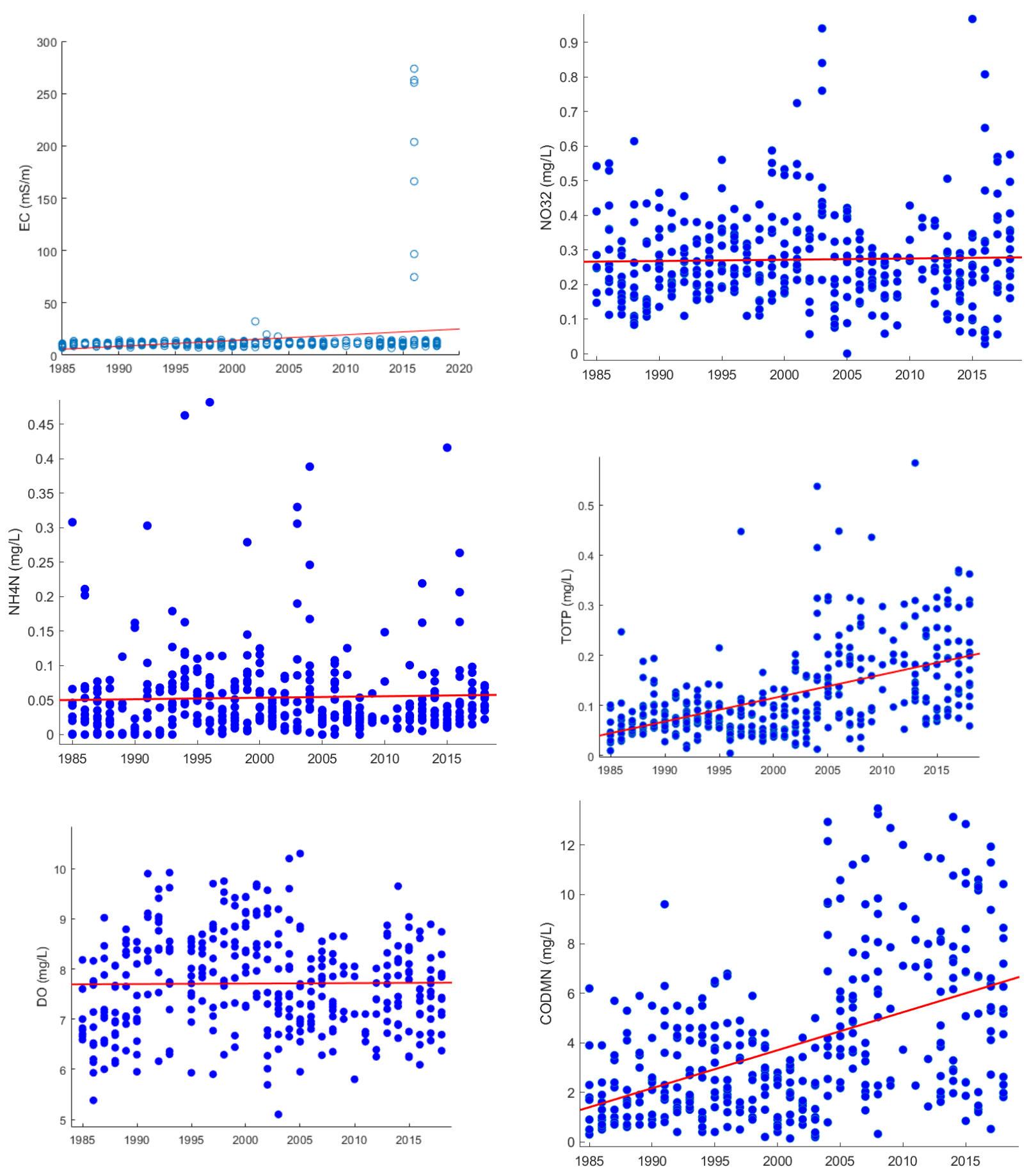

Figure A.1. Temporal trends of key water quality parameters at Chiag Rai Water Quality Monitoring Station 


\section{Annexe 1.2 Ban Hatkham (Lao PDR)}

Table A.2. Trends of key water quality parameters at Ban Hatkham Water Quality Station

\begin{tabular}{|c|c|c|c|}
\hline Parameters & Unit & Kendall tau values & p-values \\
\hline $\mathrm{pH}$ & - & -0.153 & $1.5401 \mathrm{e}-05$ \\
\hline $\mathrm{TSS}$ & $\mathrm{mg} / \mathrm{L}$ & -0.0169 & 0.64748 \\
\hline $\mathrm{EC}$ & $\mathrm{mS} / \mathrm{m}$ & 0.032 & 0.36285 \\
\hline $\mathrm{NO}_{3-2}-\mathrm{N}$ & $\mathrm{mg} / \mathrm{L}$ & 0.245 & $7.2509 \mathrm{e}-12$ \\
\hline $\mathrm{NH}_{4}-\mathrm{N}$ & $\mathrm{mg} / \mathrm{L}$ & -0.0208 & 0.58004 \\
\hline $\mathrm{TOTP}$ & $\mathrm{mg} / \mathrm{L}$ & 0.151 & $4.0496 \mathrm{e}-05$ \\
\hline $\mathrm{DO}$ & $\mathrm{mg} / \mathrm{L}$ & -0.33 & $2.22 \mathrm{e}-16$ \\
\hline CODMN & $\mathrm{mg} / \mathrm{L}$ & 0.25 & 0.00214 \\
\hline
\end{tabular}

Note:

p-value $<0.05$ indicates significant change, negative (-) Kendall tau value indicates decreasing trend, and positive $(+)$ Kendall tau value indicates increasing trend.
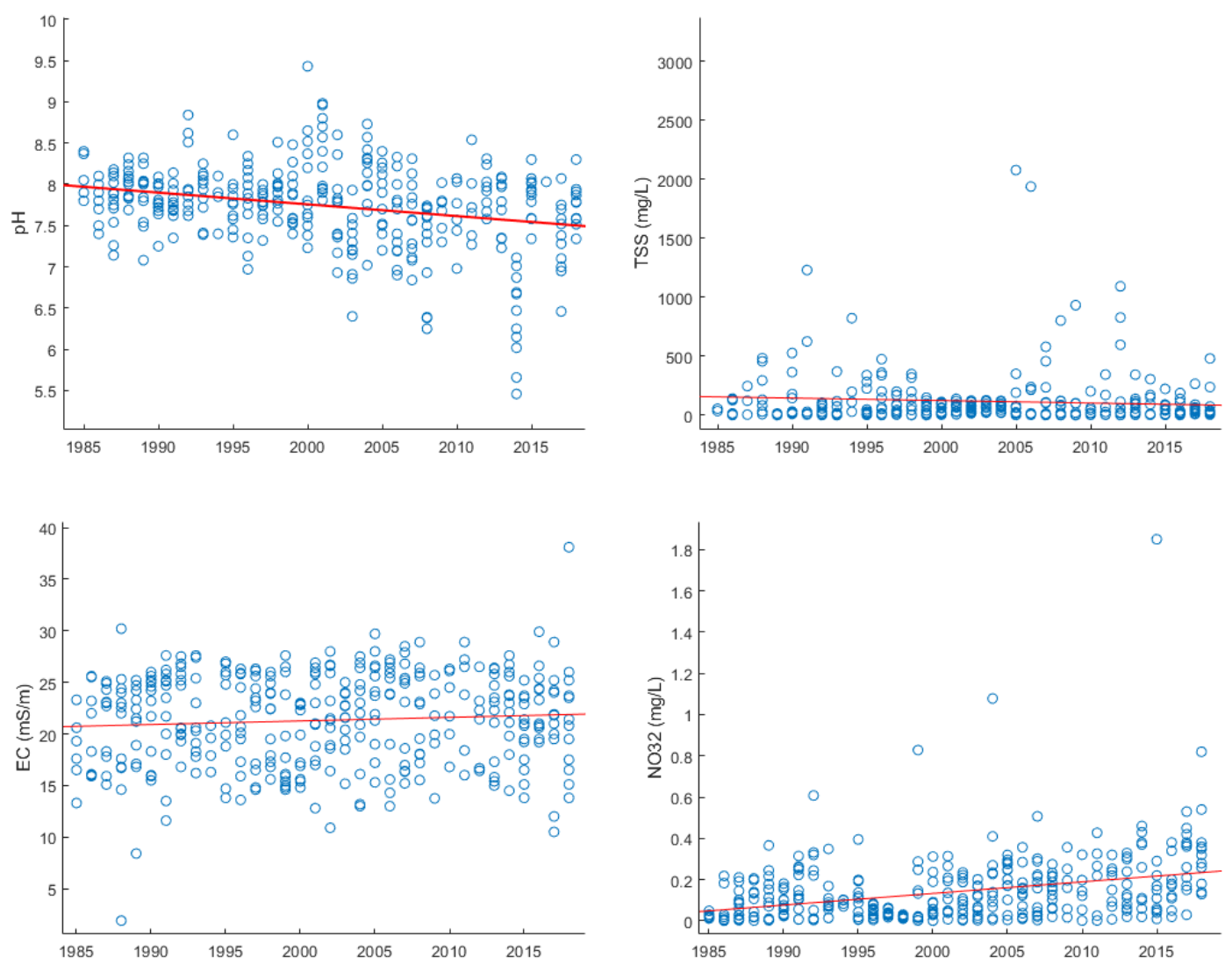

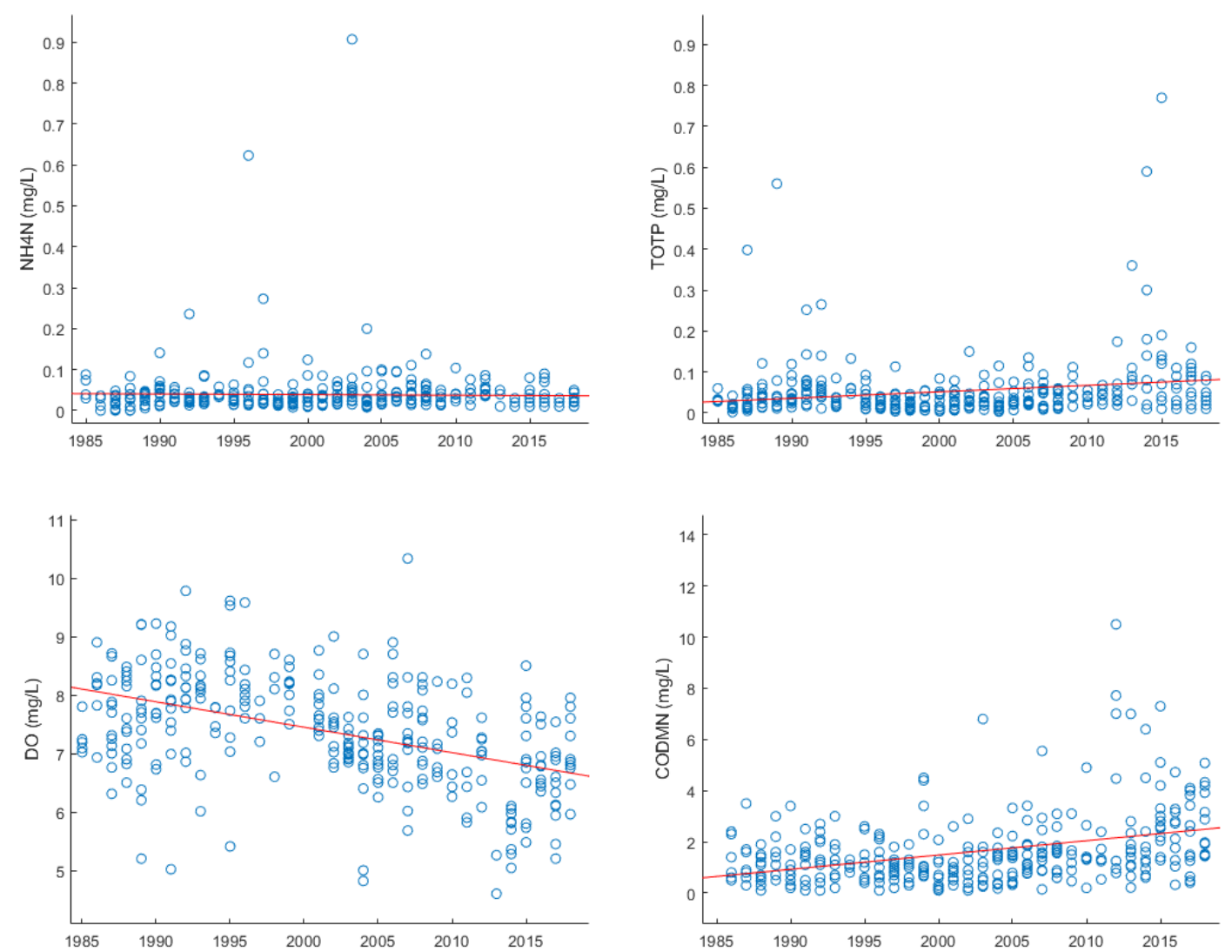

Figure A.2. Temporal trends of key water quality parameters at Ban Hatkham Water Quality Monitoring Station 
Annexe 1.3 Houay Mark Hiao (Lao PDR)

Table A.3 Trends of key water quality parameters at Houay Mark Hiao Water Quality Station

\begin{tabular}{|c|c|c|c|}
\hline Parameters & Unit & Kendall tau values & p-values \\
\hline $\mathrm{pH}$ & - & 0.242 & $1.261 \mathrm{e}-05$ \\
\hline $\mathrm{TSS}$ & $\mathrm{mg} / \mathrm{L}$ & -0.00258 & 0.96278 \\
\hline $\mathrm{EC}$ & $\mathrm{mS} / \mathrm{m}$ & 0.235 & $1.8356 \mathrm{e}-05$ \\
\hline $\mathrm{NO}_{3-2}-\mathrm{N}$ & $\mathrm{mg} / \mathrm{L}$ & 0.121 & 0.026998 \\
\hline $\mathrm{NH}_{4}-\mathrm{N}$ & $\mathrm{mg} / \mathrm{L}$ & -0.233 & $22.7509 \mathrm{e}-05$ \\
\hline TOTP & $\mathrm{mg} / \mathrm{L}$ & 0.045 & 0.42261 \\
\hline DO & $\mathrm{mg} / \mathrm{L}$ & 0.196 & 0.00037484 \\
\hline CODMN & $\mathrm{mg} / \mathrm{L}$ & -0.152 & 0.0054064 \\
\hline
\end{tabular}

Note:

p-value $<0.05$ indicates significant change, negative (-) Kendall tau value indicates decreasing trend, and positive (+) Kendall tau value indicates increasing trend.
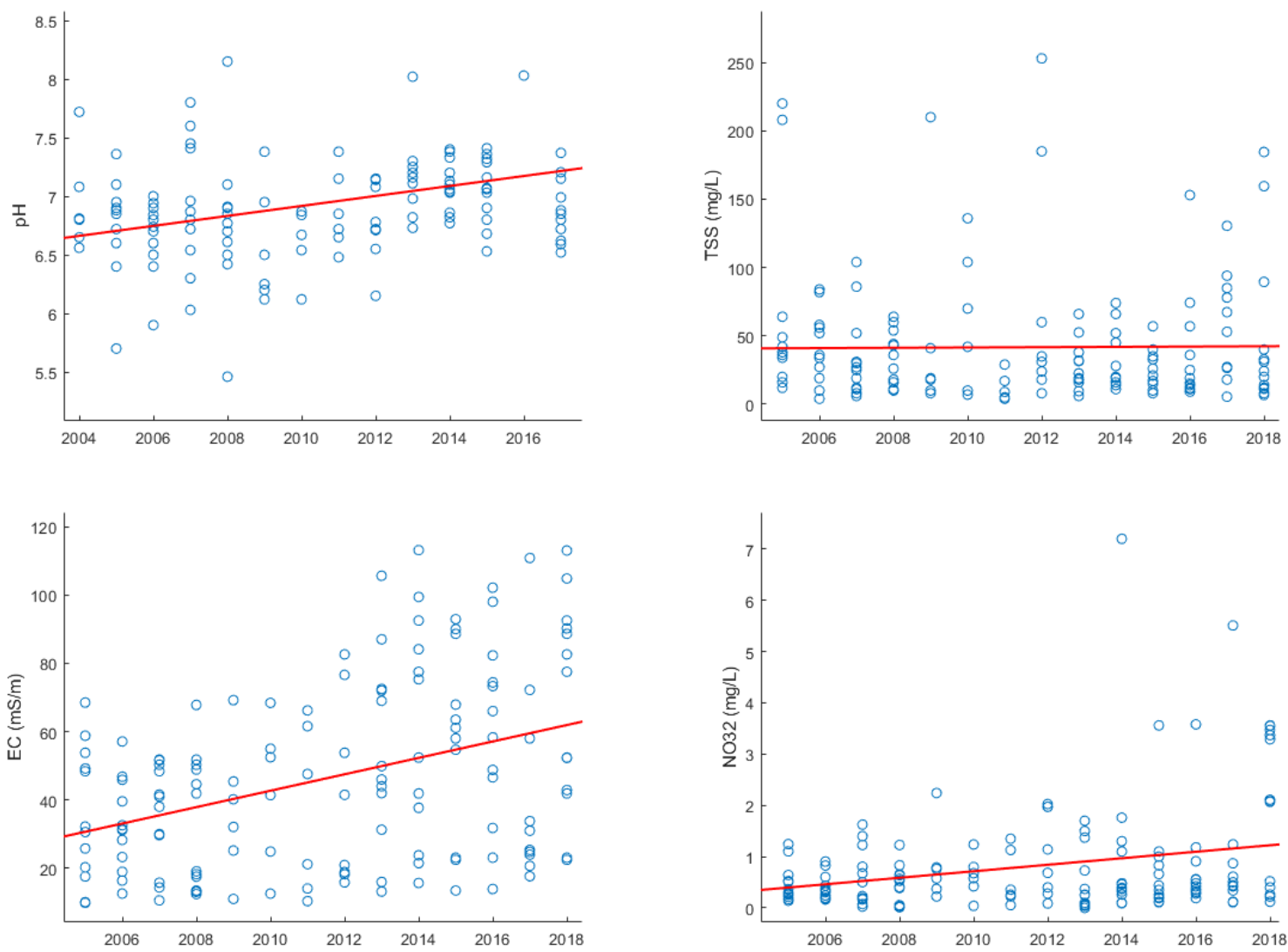

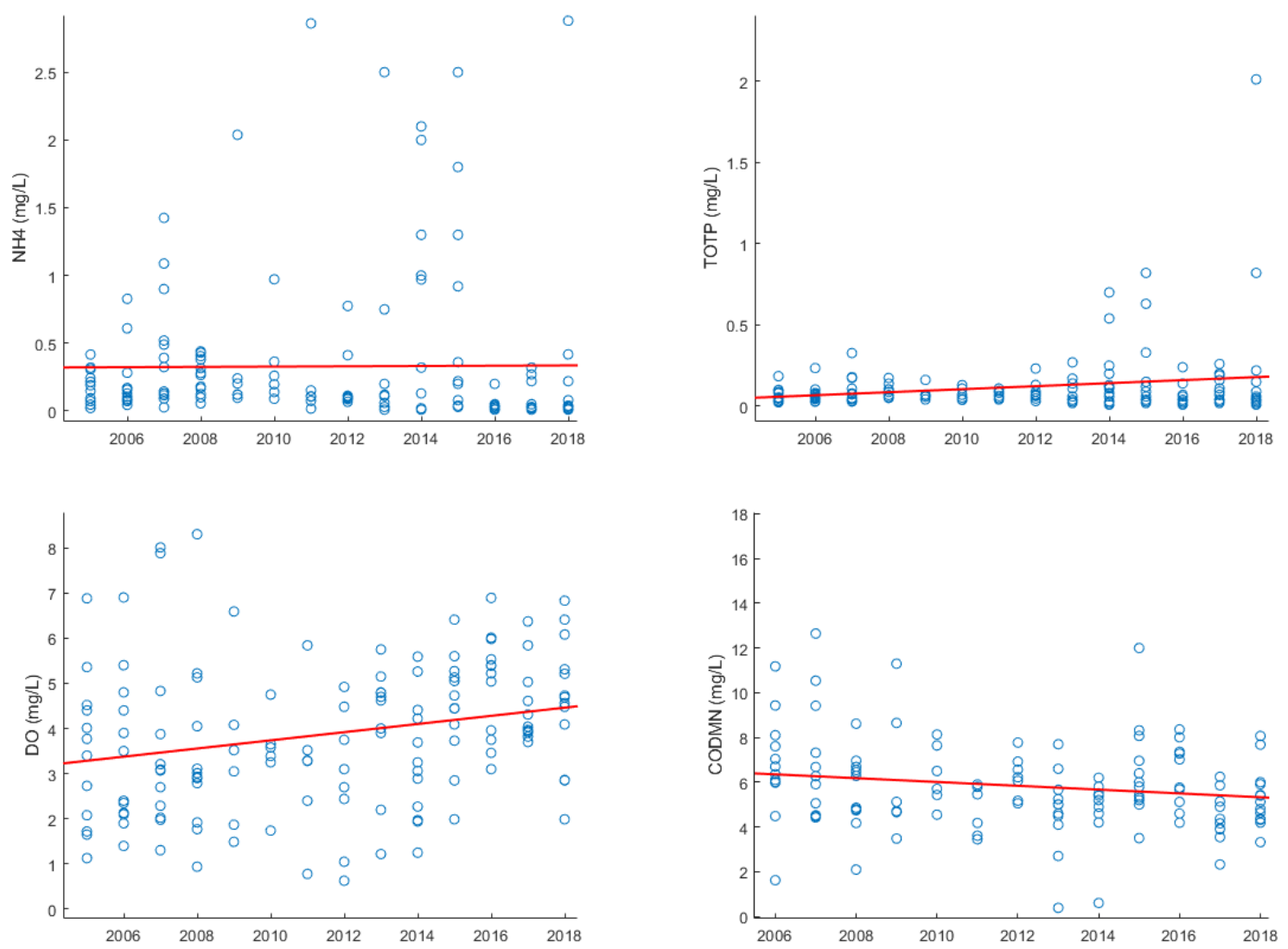

Figure A.3. Temporal trends of key water quality parameters at Houay Mak Hiao Water Quality Monitoring Station 


\section{Annex 1.4 Lumphat (Cambodia)}

Table A.4. Trends of key water quality parameters at Lumphat Water Quality Station

\begin{tabular}{|c|c|c|c|}
\hline Parameters & Unit & Kendall tau values & p-values \\
\hline $\mathrm{pH}$ & - & 0.126 & 0.021498 \\
\hline $\mathrm{TSS}$ & $\mathrm{mg} / \mathrm{L}$ & 0.0513 & 0.35454 \\
\hline $\mathrm{EC}$ & $\mathrm{ms} / \mathrm{m}$ & 0.115 & 0.035049 \\
\hline $\mathrm{NO}_{3-2}-\mathrm{N}$ & $\mathrm{mg} / \mathrm{L}$ & -0.0527 & 0.34188 \\
\hline $\mathrm{NH}_{4}-\mathrm{N}$ & $\mathrm{mg} / \mathrm{L}$ & 0.136 & 0.017019 \\
\hline $\mathrm{TOTP}$ & $\mathrm{mg} / \mathrm{L}$ & 0.0617 & 0.26939 \\
\hline $\mathrm{DO}$ & $\mathrm{mg} / \mathrm{L}$ & -0.0252 & 0.64962 \\
\hline CODMN & $\mathrm{mg} / \mathrm{L}$ & -0.265 & $1.7267 \mathrm{e}-06$ \\
\hline
\end{tabular}

Note:

p-value $<0.05$ indicates significant change, negative (-) Kendall tau value indicates decreasing trend, and positive (+) Kendall tau value indicates increasing trend.
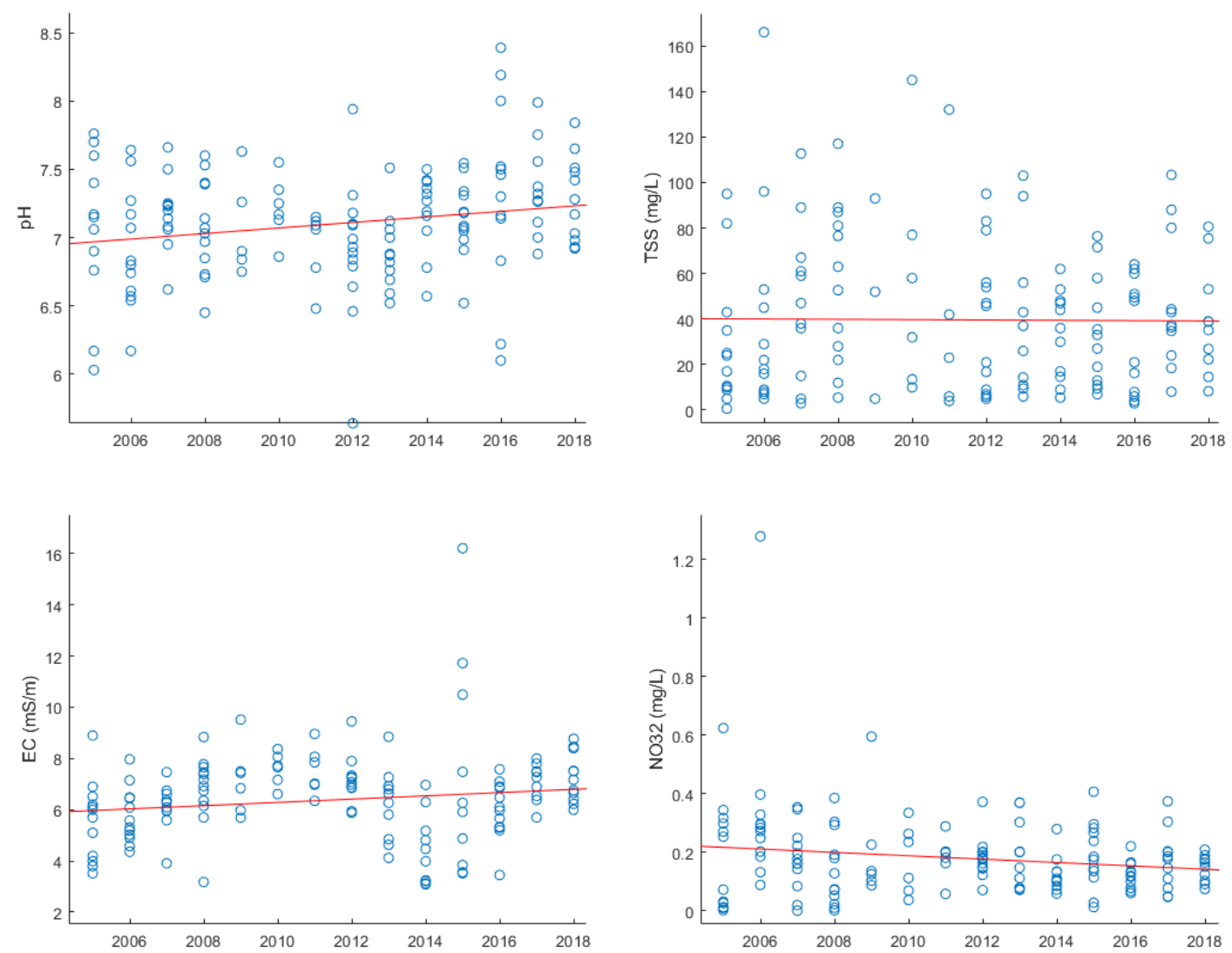

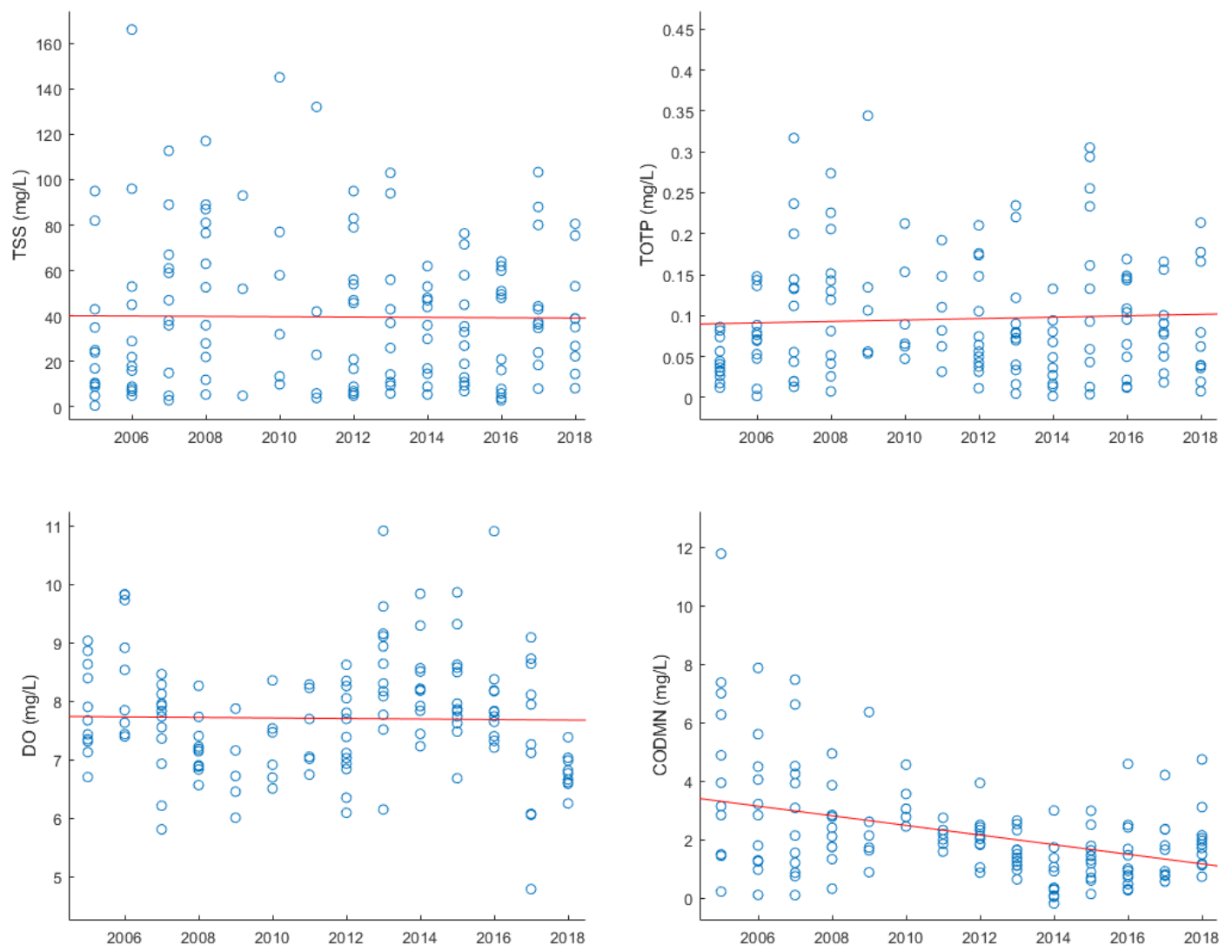

Figure A.4. Temporal trends of key water quality parameters at Lumphat Water Quality Monitoring Station 


\section{Annex 1.5 Ban Don (Viet Nam)}

Table A.5. Trends of key water quality parameters at Ban Don Water Quality Station

\begin{tabular}{|c|c|c|c|}
\hline Parameters & Unit & Kendall tau values & p-values \\
\hline $\mathrm{pH}$ & - & -0.0858 & 0.093881 \\
\hline $\mathrm{TSS}$ & $\mathrm{mg} / \mathrm{L}$ & -0.00944 & 0.8563 \\
\hline $\mathrm{EC}$ & $\mathrm{mS} / \mathrm{m}$ & 0.401 & $24.885 \mathrm{e}-15$ \\
\hline $\mathrm{NO}_{3-2}-\mathrm{N}$ & $\mathrm{mg} / \mathrm{L}$ & 0.289 & $1.956 \mathrm{e}-08$ \\
\hline $\mathrm{NH}_{4}-\mathrm{N}$ & $\mathrm{mg} / \mathrm{L}$ & 0.142 & 0.007906 \\
\hline $\mathrm{TOTP}$ & $\mathrm{mg} / \mathrm{L}$ & -0.12 & 0.022121 \\
\hline $\mathrm{DO}$ & $\mathrm{mg} / \mathrm{L}$ & -0.287 & $22.3971 \mathrm{e}-08$ \\
\hline CODMN & $\mathrm{mg} / \mathrm{L}$ & -0.00492 & 0.92365 \\
\hline
\end{tabular}

Note:

p-value $<0.05$ indicates significant change, negative (-) Kendall tau value indicates decreasing trend, and positive (+) Kendall tau value indicates increasing trend.
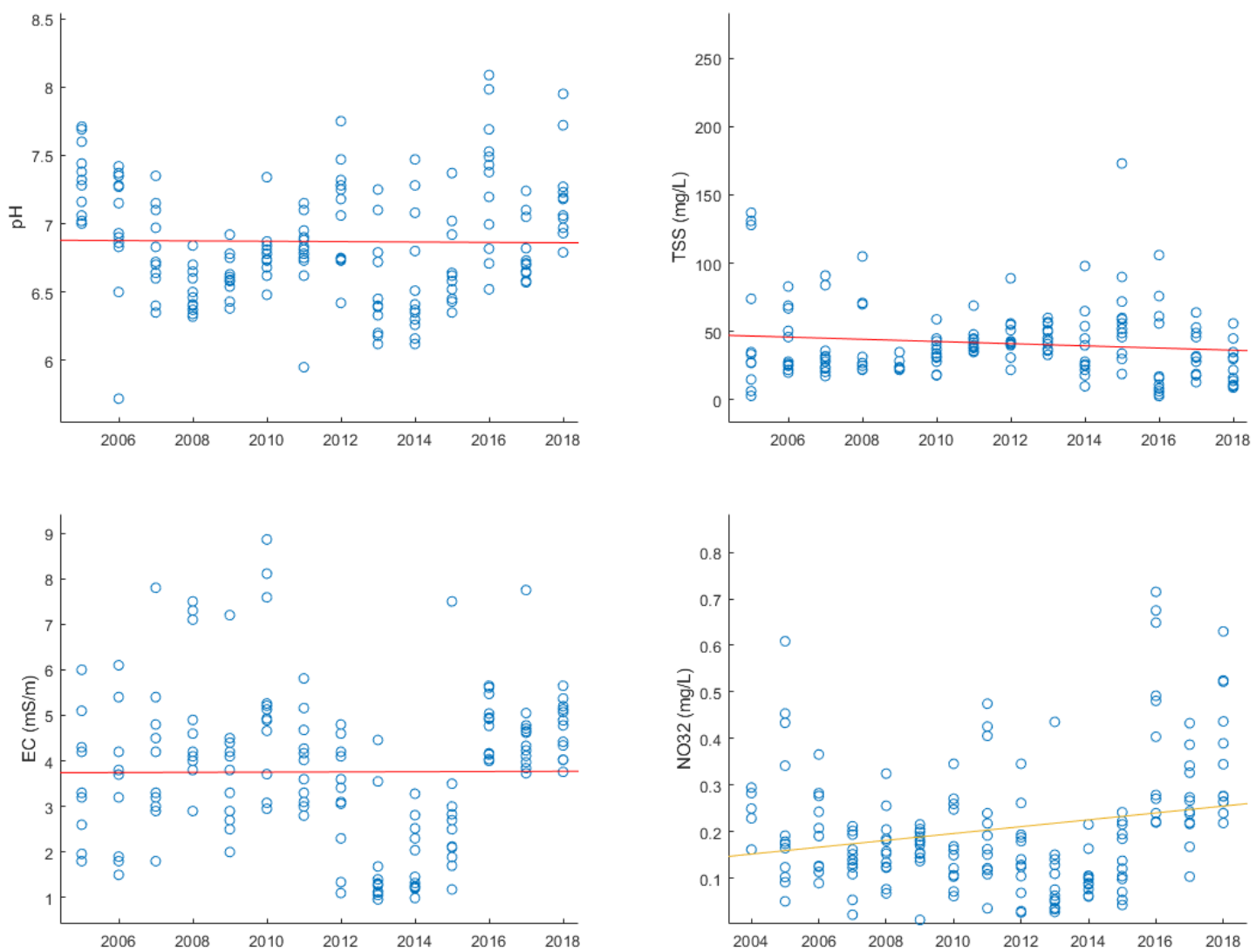

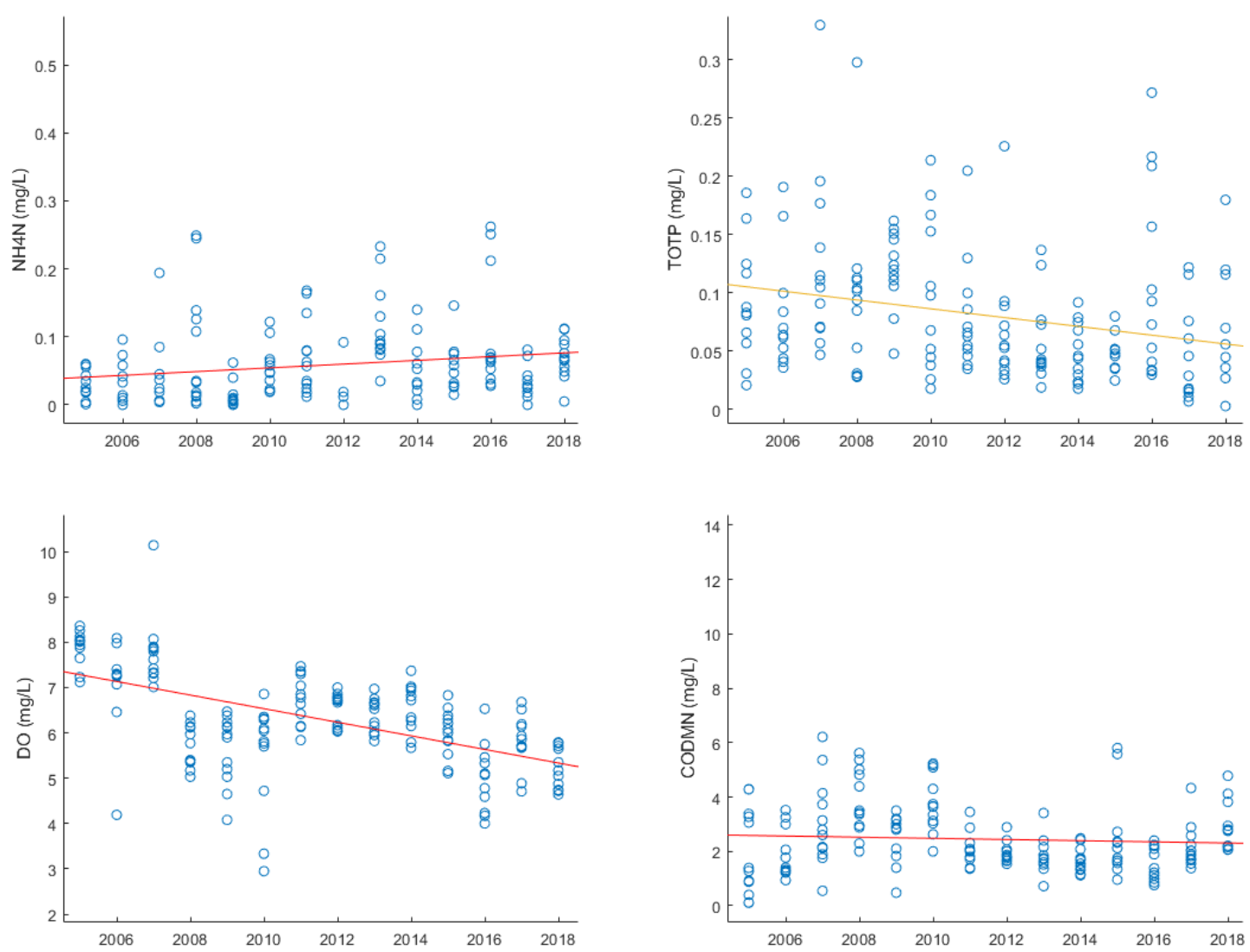

Figure A.5. Temporal trends of key water quality parameters at Ban Don Water Quality Monitoring Station 


\section{Annex 1.6 Pleicu (Viet Nam)}

Table A.6. Trends of key water quality parameters at Pleicu Water Quality Station

\begin{tabular}{|c|c|c|c|}
\hline Parameters & Unit & Kendall tau values & -values \\
\hline $\mathrm{pH}$ & - & -0.0361 & 0.4813 \\
\hline $\mathrm{TSS}$ & $\mathrm{mg} / \mathrm{L}$ & -0.0276 & 0.60006 \\
\hline $\mathrm{EC}$ & $\mathrm{mS} / \mathrm{m}$ & 0.0273 & 0.59445 \\
\hline $\mathrm{NO}_{3-2}-\mathrm{N}$ & $\mathrm{mg} / \mathrm{L}$ & 0.127 & 0.014123 \\
\hline $\mathrm{NH}_{4}-\mathrm{N}$ & $\mathrm{mg} / \mathrm{L}$ & 0.139 & 0.009626 \\
\hline $\mathrm{TOTP}$ & $\mathrm{mg} / \mathrm{L}$ & -0.21 & $6.8628 \mathrm{e}-05$ \\
\hline $\mathrm{DO}$ & $\mathrm{mg} / \mathrm{L}$ & -0.422 & $2.2204 \mathrm{e}-16$ \\
\hline CODMN & $\mathrm{mg} / \mathrm{L}$ & -0.0362 & 0.4808 \\
\hline
\end{tabular}

Note:

p-value $<0.05$ indicates significant change, negative (-) Kendall tau value indicates decreasing trend, and positive (+) Kendall tau value indicates increasing trend.
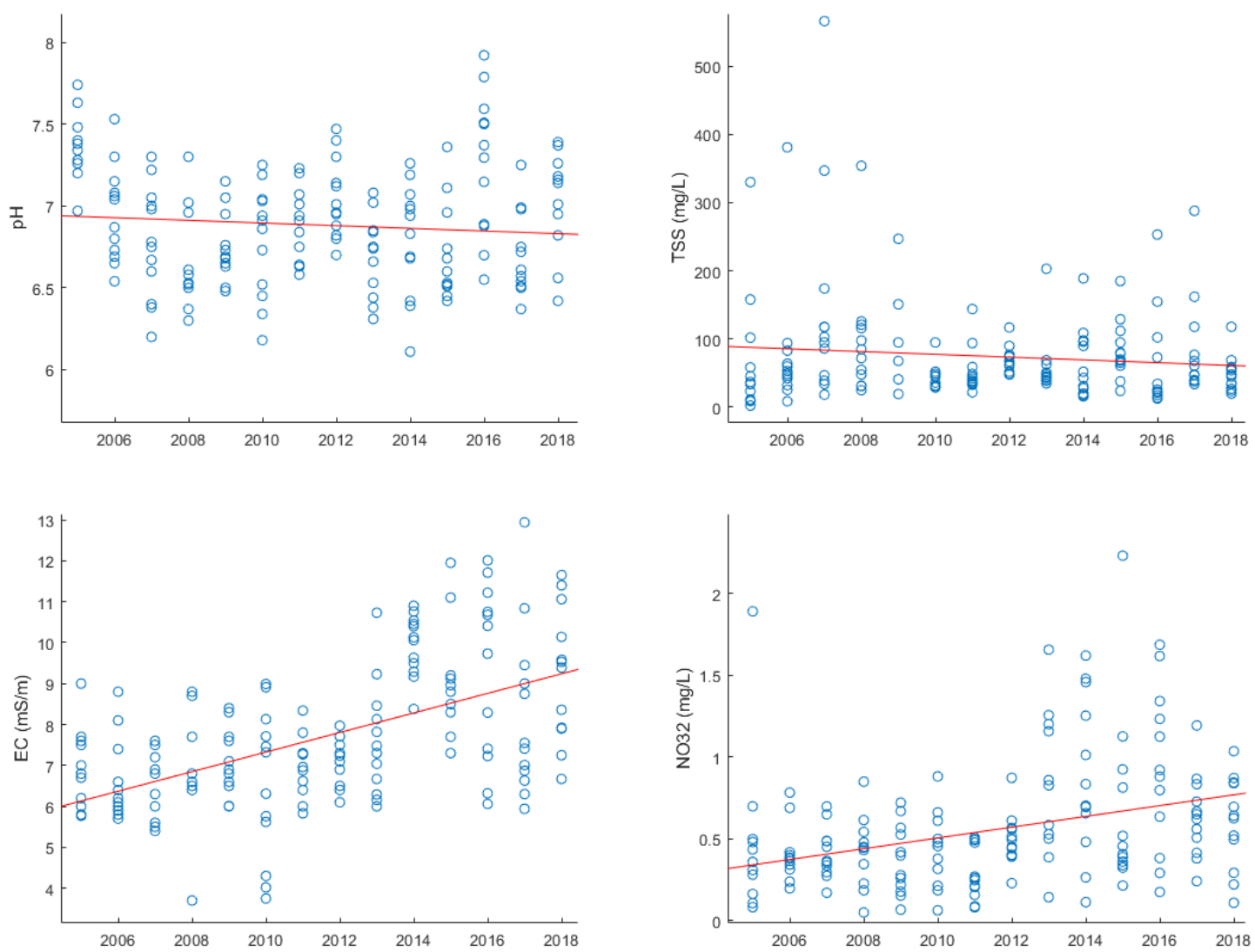

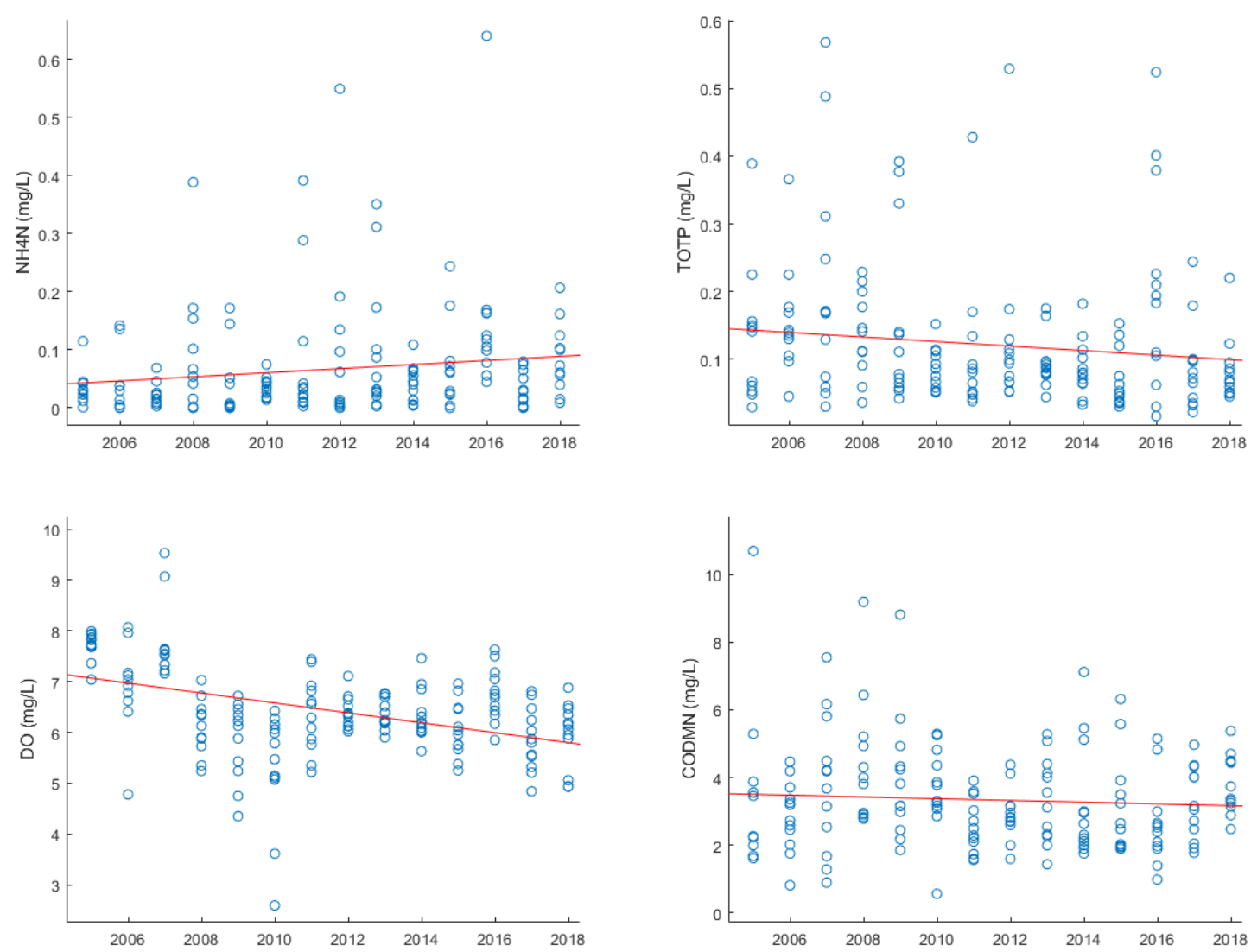

Figure A.6. Temporal trends of key water quality parameters at Pleicu Water Quality Monitoring Station 


\section{Annex 1.7 Prek Kdam (Cambodia)}

Table A.6. Trends of key water quality parameters at Prek Kdam Water Quality Station

\begin{tabular}{|c|c|c|c|}
\hline Parameters & Unit & Kendall tau values & p-values \\
\hline $\mathrm{pH}$ & - & 0.0505 & 0.12218 \\
\hline $\mathrm{TSS}$ & $\mathrm{mg} / \mathrm{L}$ & 0.108 & 0.0011138 \\
\hline $\mathrm{EC}$ & $\mathrm{mS} / \mathrm{m}$ & -0.0701 & 20.031549 \\
\hline $\mathrm{NO}_{3-2}-\mathrm{N}$ & $\mathrm{mg} / \mathrm{L}$ & -0.0663 & 0.044425 \\
\hline $\mathrm{NH}_{4}-\mathrm{N}$ & $\mathrm{mg} / \mathrm{L}$ & -0.0663 & 0.044425 \\
\hline $\mathrm{TOTP}$ & $\mathrm{mg} / \mathrm{L}$ & 0.274 & $2.2204 \mathrm{e}-16$ \\
\hline $\mathrm{DO}$ & $\mathrm{mg} / \mathrm{L}$ & 0.277 & $2.22 \mathrm{e}-16$ \\
\hline CODMN & $\mathrm{mg} / \mathrm{L}$ & -0.229 & $2.3481 \mathrm{e}-12$ \\
\hline
\end{tabular}

Note:

p-value $<0.05$ indicates significant change, negative (-) Kendall tau value indicates decreasing trend, and positive (+) Kendall tau value indicates increasing trend.
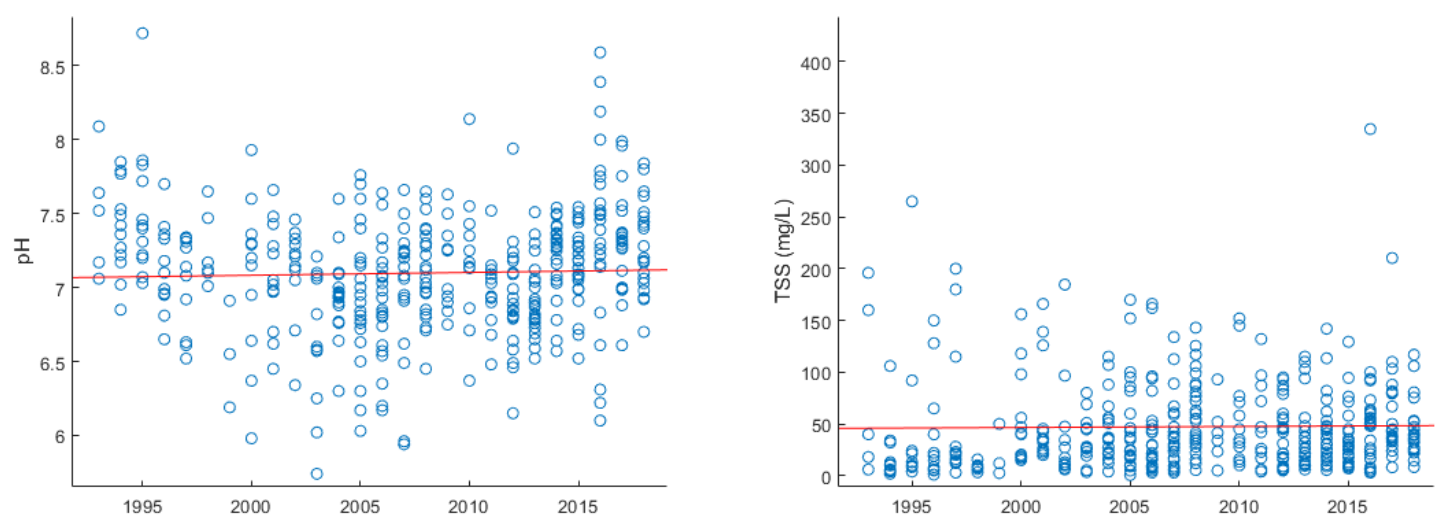

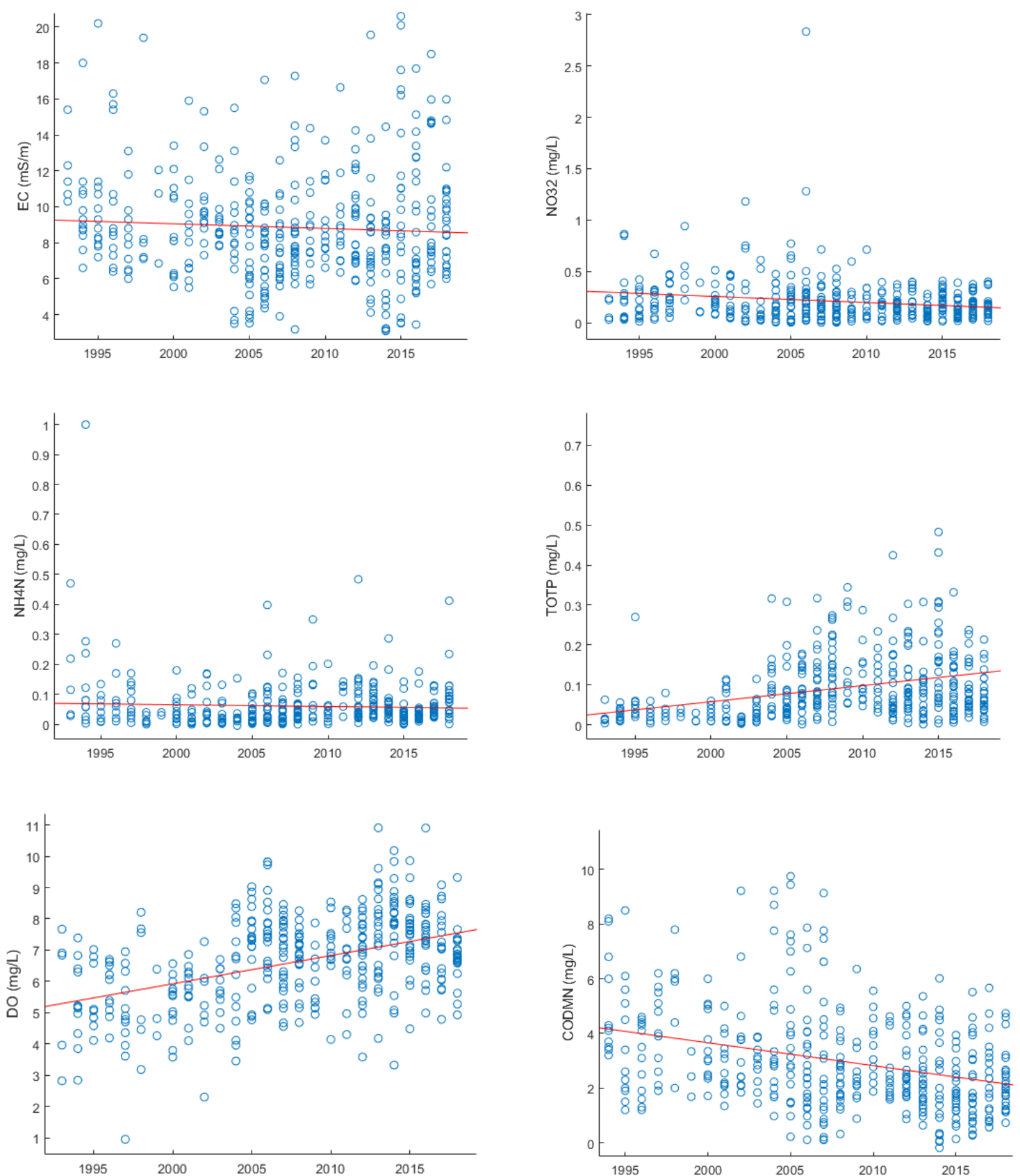

Figure A.7. Temporal trends of key water quality parameters at Prek Kdam Water Quality Monitoring Station 


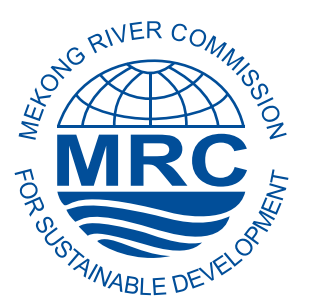

Mekong River Commission Secretariat

P. O. Box 6101, 184 Fa Ngoum Road, Unit 18 Ban Sithane Neua, Sikhottabong District, Vientiane 01000, Lao PDR

Tel: +85621263 263. Fax: +85621263264

www.mrcmekong.org

(C) Mekong River Commission 2021 